AperTO - Archivio Istituzionale Open Access dell'Università di Torino

\title{
Hurrian Personal names in the Kingdom of Hatti
}

\section{This is the author's manuscript}

Original Citation:

Availability:

This version is available http://hdl.handle.net/2318/87209

since 2015-12-14T10:36:03Z

Publisher:

Logisma

Terms of use:

Open Access

Anyone can freely access the full text of works made available as "Open Access". Works made available under a Creative Commons license can be used according to the terms and conditions of said license. Use of all other works requires consent of the right holder (author or publisher) if not exempted from copyright protection by the applicable law. 
Eothen

Collana di studi sulle civiltà dell'Oriente antico

18 



\section{Gothen}

Collana di studi sulle civiltà dell'Oriente antico

fondata da Fiorella Imparati e Giovanni Pugliese Carratelli diretta da Stefano de Martino

Stefano de Martino

\section{HURRIAN PERSONAL NAMES \\ IN THE KINGDOM OF HATTI}

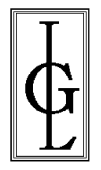

LoGisma editore 
Università degli Studi di Torino - Dipartimento di Scienze Antropologiche, Archeologiche e Storico Territoriali

This volume has been printed thanks to a contribution MiUR, PRIN.

Stefano de Martino, Hurrian Personal Names in the Kingdom of Hatti

Copyright (C) 2011 Stefano de Martino

Copyright (C) 2011 LoGisma editore

www.logisma.it - logisma@tin.it

ISBN 978-88-87621-67-5 
Table of Contents

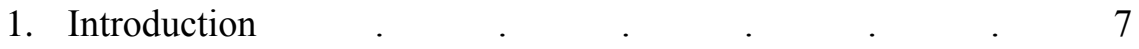

2. The Members of the Royal Family of Hatti

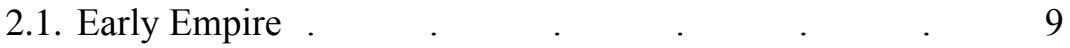

2.2. Imperial Age . $\quad$. $\quad$. $\quad$. $\quad$. $\quad$. 13

2.3. Between Tradition and Innovation . . . . $\quad 17$

3. Kings and Rulers of Subordinated Countries . . 21

4. Hurrian Personal Names in the Hittite Society

4.1. Old Kingdom . $\quad$. $\quad$. $\quad$. $\quad$. $\quad$. 25

4.2. Early Empire . . . . . . . . . 25

4.3. Imperial Age . $\quad$. $\quad$. $\quad$. $\quad$. $\quad$. 29

4.4. Hurrian Personal Names: Sociological Distribution

4.4.1. State Officials and Dignitaries . $\quad$. $\quad 35$

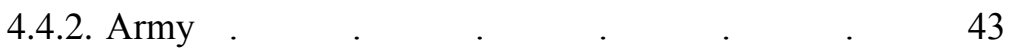

4.4.3. Royal Messengers $\quad$. $\quad$. $\quad$. $\quad$. 47

4.4.4. Palace Personnel and People Living at Court . 49

4.4.5. Scribes and Chiefs of the Scribes . . $\quad 53$

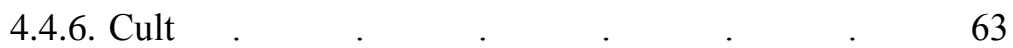

4.4.7. Experts of Medicine . . . . $\quad$. 75

4.4.8. Other or Unknown Professions . $\quad$. $\quad$. $\quad 77$

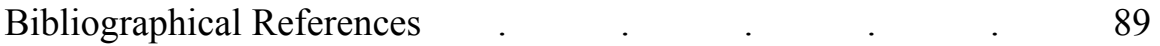

Personal Names Examined $\quad . \quad$. $\quad$. $\quad$. $\quad$. 105 



\section{INTRODUCTION}

Hurrian personal names are present in texts from many archives of the Ancient Near East. ${ }^{1}$ The publication of personal names documented in the Nuzi texts, with a first volume by I.J. Gelb, P.M. Purves, A.A. MacRae (1943) and a second one by E. Cassin (1977), has been the first important contribution to the knowledge of Hurrian names of the Late Bronze Age. The following step was A. Draffkorn's PhD Dissertation, "Hurrians and Hurrian at Alalah: An Ethno-Linguistic Analysis" (1959), where this scholar not only collected and analysed Hurrian names on a linguistic level, but also examined the percentage of them in the different periods (Alalah VII and IV) and in the different components of the Alalah society. Subsequently Hurrian names in the Mari texts have been studied by J. Sasson (1974), who has collected also Hurrian names preserved in the Tell al-Rimah archives (1979).

In more recent years investigations on Hurrian onomasticon have increased: Hurrian names in the Emar texts have been investigated by R. Pruzsinszky (2003); a socially oriented study on the use of Hurrian names at Ugarit is the topic of an article of W. van Soldt (2003); Th. Richter (2004) has examined Hurrian names in the textual sources of different regions of the Ancient Near East during the third and the second millennium; in another article (1998) he has studied Hurrian names that are documented in the prism of Tunip-Tešob, ruler of Tigunani; Hurrian names in the Kültepe texts have been discussed by G. Wilhelm (2008). To this scholar we owe also an excellent synthesis on Hurrian personal names from all ages (1998). ${ }^{2}$ Lastly, Th. Richter (2010) has just published a detailed analysis of many Hurrian names that he has studied according on their linguistic components.

Concerning Hurrian names in the Hittite texts, E. Laroche $(1966,1981)$ has collected all personal names in the Hittite tablets; his work comprehends also Hurrian names. ${ }^{3}$ The same can be said for the recent book of Th. Zehnder (2010) that deals with feminine personal names in the Hittite

\footnotetext{
${ }^{1}$ See lastly Richter 2010, 525.

${ }^{2}$ See also Giorgieri 2000 b.

${ }^{3}$ See also Laroche 1976, 19-22.
} 
tablets. Moreover, several scholars have studied some of the Hurrian names documented in Hittite texts, but an analysis specifically devoted to the Hurrian onomasticon of Hatti is lacking.

With the present work I am making an attempt to better understand whether the percentage and the typology of Hurrian personal names changed from time to time and whether we can recognize differentiations in the Hurrian onomasticon among the various components and groups of the Hittite society.

In consideration of this kind of analysis, I have collected personal names that can be considered as Hurrian and I have studied them in their pertinent chronological and prosopographic context with the aim of knowing family background and social condition of those individuals who held Hurrian names.

In the first part of this booklet I have examined the Hurrian names of the members of the royal family of Hatti and in the second part those of other persons, who, according to the Hittite texts, lived in the kingdom of Hatti. ${ }^{4}$

I have decided to include in this investigation also hybrid names, that is Hurro-Hittite and Hurro-Luwian names, because I think that these names too are a manifestation and, therefore, a signal of the diffusion of the Hurrian culture or at least of a certain trend.

In the presentation of the onomastic material I have adopted the following chronological schema: Old Kingdom (from Labarna I to Muwattalli I), Early Empire (from Tuthaliya I/II to Tuhaliya III), Imperial Age (from Šuppiluliuma I to Šuppiluliuma II).

$$
* * *
$$

My special thanks go to some colleagues who have given me comments and suggestions on individual aspects and problems; these are Elena Devecchi, Mauro Giorgieri, J. David Hawkins, H. Craig Melchert, Itamar Singer. It goes without saying that the responsibility for the content of this book rests only with me.

${ }^{4}$ I have excluded from my present analisys personal names documented in the archives of cities politically subordinated to Hatti such as Ugarit, Alalah, Emar, that, as we have already seen, have been thoroughly investigated by other scholars. A study on the Hurrian names of officials and members of the royal family of Kargamiš is on my agenda. 


\section{MEMBERS OF THE ROYAL FAMILY OF HATTI}

\subsection{Early Empire}

None of the members of the royal family had a Hurrian name during the Old Kingdom. The name BU-Šarruma, ${ }^{5}$ documented in one of the texts of the so called Offering Lists for the dead Kings, KUB 11. $7+$ I 19, ${ }^{6}$ was presumably held by a member of the royal family of the Imperial $\mathrm{Age}^{7}$ and not by Hattušili I's father or grandfather, as R. Beal (2003, 14-20) had thought.

Things change in the Early Empire, that is during the reigns of Tuthaliya I/II, Arnuwanda I and Tuthaliya III, when many members of the Hittite royal family had Hurrian names. Queen Nikkal-madi, Tuthaliya I's wife, was the first member of the royal family who had a Hurrian name; some scholars believe that she was a princess of Kizzuwatna and this might explain her Hurrian name. ${ }^{8}$

In the following generation Ašmu-Nikkal, daughter of Tuthaliya I/II and Nikkal-madi and wife of Arnuwanda I, held a Hurrian name. Arnuwanda I and Ašmu-Nikkal had many children: their son, who took the throne and had the dynastic name Tuthaliya, bore also the Hurrian name Tašmi-Šarri. Three others of this royal couple's children had Anatolian (either Hittite or Luwian) names: Kantuzili, who received the name of his father's grandfather, Mannini ${ }^{9}$ and Pariyawatra. ${ }^{10}$

An individual named Ašmi-Šarruma, son of Arnuwanda, is documented in the Offering Lists, KUB $11.7+$ rev. $6 .{ }^{11} \mathrm{R}$. Beal considers him one of Arnuwanda I's sons. ${ }^{12}$ This hypothesis is supported by the fact that in this

${ }^{5}$ For the Hurrian reading of BU see Hutter 1991, 40 n. 13; Carruba 2008, 104 n. 24 (= hišmi); van den Hout 1995, 135-136 (= tagi).

${ }^{6}$ See Otten 1951, 65.

${ }^{7}$ See Taracha 2004, 637.

${ }^{8}$ See Houwink ten Cate 1998; Beal 2002, 69, and, more recently, Freu 2007, 118; Marizza 2007a, 2 n. 11.

${ }^{9}$ See now Zehnder 2010, 215.

${ }^{10}$ See lastly Yakubovich 2010, 274.

${ }^{11}$ See Otten 1951, 66; Carruba 2008, 139-140.

${ }^{12}$ Beal 2002, 66. 
text Ašmi-Šarruma appears together with Mannini and in the preceding paragraphs we find, before, kings of the Old Kingdom and, then, Arnuwanda and Ašmu-Nikkal. D. Hawkins proposes that Ašmi-Šarruma, prince (REX.FILIUS) and owner of the Nişantepe seal no. 75, is the same person who is mentioned in the Offering Lists. ${ }^{13}$ If we date Prince Ašmi-Šarruma of KUB 11.7 to the time of Arnuwanda I, attributing to him the Nişantepe impression might be problematic, because in this archive, according to $\mathrm{S}$. Herbordt, there are no bullae of the period before Šuppiluliuma I. ${ }^{14}$

Passing to the following generation, Tuthaliya III had two wives: TaduHeba and Šatandu-Heba, ${ }^{15}$ both names are Hurrian.

Also the woman whose name was Ašmu-Heba belonged in some way to the royal family; ${ }^{16}$ she is mentioned in a very fragmentary passage of the ritual, attributable to Tuthaliya I, ${ }^{17} \mathrm{KBo} 15.10+\mathrm{III} 26 .{ }^{18}$ She might have been the owner of the seal, the impression of which is preserved on a bulla from Nişantepe; here Ašmu-Heba bears the title princess (REX.FILIA). ${ }^{19}$

In another ritual, related to KBo 15.10 +, that is KBo $20.34+$ rev. 12', we find the name Attai; this name appears also in the texts KBo 17. 104 II 7 [, that belongs to the Hantitaššu ritual. ${ }^{20}$ According to A. Ünal $(1996,58)$ Attai was a contemporary of Ziplantawiya, ${ }^{21}$ Tuthaliya I's sister; Ph. Houwink ten Cate $(1998,46)$, on the basis of the fragmentary passage KBo $20.34+$ rev. 12'-13', believes that he was Ziplatawiya's son.

Other individuals, who were members of the royal family, are MušuHeba, who might have been Kantuzili's wife, ${ }^{22}$ and Tulbi-Tešob, who presumably was Mannini's son. ${ }^{23}$

${ }^{13}$ Hawkins 2005, 251; for this seal impression see Herbordt 2005, 126.

${ }^{14}$ Herbordt 2005, 4.

${ }^{15}$ On this Queen see lastly de Martino 2010a.

${ }^{16}$ The hypothesis advanced by Freu $(2007,97)$, that she was Hattušili II's wife, of course, cannot be shared by those who do not believe in the existence of this king.

${ }^{17}$ See Miller 2004, 352 n. 491; on the history of the tradition of this text see now Christiansen 2007, 93-107.

${ }^{18}$ See Szabó 1971, 38-39; f

${ }^{19}$ See Herbordt 2005, 116 no. 11; regarding the problem whether some of the seal impressions from Nişantepe can be dated to the early Empire see n. 14.

${ }^{20}$ See Ünal 1996, 20 n. 35.

${ }^{21}$ On this personage see Szabó 1971, 88 n. 10; Freu, 2007, 22.

${ }^{22}$ See lastly de Martino 2010b, 132-133.

${ }^{23}$ See Marizza 2007a, 30-33. 
The royal family in the Early Empire

(Hurrian names are in italics)

\section{Kantuzili}

father of:

Tuthaliya I/II

and

Ziplantawiya

husband of Nikkal-madi

parents of:

mother? of:

Ašmu-Nikkal wife of Arnuwanda I

Attai

parents of:

1) Ašmi-Šarruma (?)

2) Tutḩaliya III/Tašmi-Šarri

husband of Tadu-Heba and Šatandu-Heba

and father of: Tuthaliya, Šuppiluliuma, Zida

3) Kantuzili husband ? of Mušu-Heba

4) Mannini father ? of Tulbi-Tešob

5) Pariyawatra

Princess $A \check{s} m u-H e b a$ (relation to the royal family unknown) 
Let us take a look at the linguistic analysis of these names. The greatest part of them are "Satznamen"; ${ }^{24}$ some of them are composed with a verb in the third person and a divine name:

\begin{tabular}{|c|c|}
\hline${ }^{\mathrm{f}}$ Ašmu-Nikkal & $a z ̌ m=o-N i k k a l^{25}$ \\
\hline f Tadu-Heba & $t a d=o-$ Hebat $^{26}$ "Hebat loved her" \\
\hline f̌̌atandu-Heba & $\check{s} a d=a n d=o-H e b a t^{27}$ \\
\hline${ }^{\mathrm{f}} \mathrm{Ašmu}-\mathrm{Heba}$ & $a z ̌ m=o-H e b a t$ \\
\hline${ }^{\mathrm{f}}$ Mušu-Hueba & $m u \check{z}=o-H e b a t$ "Hebat made her perfect" \\
\hline${ }^{\mathrm{m}}$ Ašmi-Šarruma & $a \check{m} m=i(=b)-\check{S} a r r u m a$ \\
\hline${ }^{\mathrm{n}}$ Tulbi-Tešob & tulb=i $(=b)-$ Tešob "Tešob made prosper" 29 \\
\hline
\end{tabular}

Other names are nominal clauses; this is the case of Nikkal-madi $=$ "Nikkal (is) wisdom/wise". ${ }^{30}$ The analysis of Tašmi-Šarri remains uncertain. It might be composed with a verbal form ${ }^{31}, t a z ̌ m=i(=b)=\check{s}$ arri "the (deified) king .... ${ }^{32}$ "; otherwise it might be a nominal clause either with an adjective (V. Haas ${ }^{33}$ had proposed the meaning "strong" for the word tažmi and had connected it to the name of the god Tašmišu) or with a noun (I. Wegner ${ }^{34}$ had interpreted it as a noun in $-m e$, as for example pura $=m e$ "slave") and the verb "to be" unexpressed (= "the (deified) king is ...."). ${ }^{35}$

${ }^{24}$ On names of this kind see Wilhelm 1998a.

${ }^{25}$ On the root $a z ̌ m$ - see de Martino - Giorgieri 2008, 127.

${ }^{26}$ For the lack of the suffix $-m$ in names composed with Hebat see Wilhelm 1992, 668, 669; Wilhelm, 1998, 123; Giorgieri 2000b, 287-288.

${ }^{27}$ See Dinçol - Dinçol - Hawkins - Wilhelm 1993, 102 n. 78.

${ }^{28}$ See Giorgieri 2000b, 286; for other names composed with the root $m u z ̌$ - see Richter 2010, 522.

${ }^{29}$ For this kind of names and the fall of the suffix $-b$ see Giorgieri 2000b, 286; for the meaning of tulb- see Salvini 1996b, 86.

${ }^{30}$ For madi see lastly Wegner 2007, 266; see also here n. 565.

${ }^{31}$ For a verb tažm- see Salvini 1991, 179.

${ }^{32}$ For the second element of this name see Salvini 1991, 179.

${ }^{33}$ Haas 1994, 309.

${ }^{34}$ Wegner 1990, 303 n. 14.

${ }^{35}$ For similar names see Giorgieri 2000b, 290. 
The only exception to the adoption of this kind of names for the members of the royal family is Attai; this name is the Hurrian word for "father" $(a t t a=i){ }^{36}$ it belongs to a different category of names, as for example Ašte "woman”, or Šalli “daughter" etc. ${ }^{37}$

\subsection{Imperial Age}

Tuthaliya III's follower, Šuppiluliuma I, apparently interrupted the trend of the Hurrian names. He had a Hittite name from the geographical name ${ }^{38}$ ÍD/URU Šuppiluli(ya) ${ }^{39}$ and his brother Zida held a name that was the Luwian word for "man" $(z i d a / \widehat{\imath})$. Also Šuppiluliuma I's children - at least those who are known to us by name - had non-Hurrian Anatolian names: Arnuwanda (II), Zannanza, Piyaššili, ${ }^{40}$ Telipinu, Muršili (II), ${ }^{\mathrm{f}}$ Muwatti; the same can be said for Zida's children: Hutupiyanza and Arma-Tarhunta. The first wife of Šppiluliuma I held the name Henti; Th. Zehnder (2010, 155), following Laroche $(1966,357)$, advances the hypothesis that this name might be Hurrian, since names such as Hinitya ${ }^{41}$ and $\mathrm{Hinti}^{42}$ are documented at Nuzi. Despite this, as Th. Zehnder observes, we do not know any Hurrian root hilent- and the etymology of this personal names remains obscure, therefore we cannot say for sure if it is Hurrian or not.

If ${ }^{\mathrm{m}}$ Tulbi-Šarruma DUMU.NITA ${ }^{\mathrm{m}}$ Arnuw[anda of KBo 13.42 1. 6', a fragment of the Offering Lists for the dead Kings, was really the son of Arnuwanda II as I. Singer $(2003,344)$ proposes, Arnuwanda II was the first member of the royal family of this time who wanted a Hurrian name for one of his children.

${ }^{36}$ See lastly de Martino - Giorgieri 2008, 142-144; since the Hittite word for "father" is atta and this personal name is Attai, that is exactly corresponding to the Hurrian term and personal name, the hypothesis that the name of Ziplantawiya's son belongs to the Hurrian language and not the Hittite one is very reasonable. On the Hittite personal name Atta se lastly Zehnder 2010, 48.

${ }^{37}$ See Wilhelm 1998a, 125.

${ }^{38}$ Also some of his predecessors had names of geographical inspiration, such as Arnuwanda and Tuthaliya (mountain names, see Gonnet 1968, 117-118, 143).

${ }^{39}$ See Hoffner 1998, 118; Zehnder 2010, 92.

${ }^{40}$ We can presume that Piyaššili bore his second Hurrian name Šarri-Kušuh only when he became king of Kargamiš, see $\S 2.3$.

${ }^{41}$ See Gelb - Purves - MacRae 1943, 61.

${ }^{42}$ See Cassin 1977, 58. 
Muršili II named his four children Hualpa-šulupi, Muwatalli (II), Hattušili (III) and ${ }^{f}$ Maššana-uzzi. While the last three names belong to the Anatolian tradition, the first one, Halpa-šulupi ${ }^{43}$ contains the name of the Syrian city Halpa and the second element is the name of a bird, ${ }^{44}$ šulupi-.

Muwatalli II reintroduced Hurrian names in the royal family; he opted for names composed with Tešob: in fact he had a Hurrian second name, that is Šarri-Tešob "Tešob (is) king" as some seal impressions (SBo I no. 38/B. $250)^{45}$ witness; then he named his two sons, respectively, Urhi-Tešob (= "Tešob (is) faithful (to me") ${ }^{46}$ and Ulmi-Tešob ${ }^{47}$ (" = Tešob (is my) weapon"). ${ }^{48}$ Muwattalli II's will of rupture with the old Central Anatolian tradition and also his "Luwian orientation", 49 that clearly appears from his political and theological decisions, can explain his predilection for Hurrian personal names.

The identity of Tanu-Heba is still controversial; she might have been Muwatalli II's wife ${ }^{50}$ or Muršili II's last wife ${ }^{51}$ she held a name that was similar to those of the queens of the Early Empire: $\tan =\mathrm{O}-\mathrm{Hebat}$ "Hebat made her".

Hattušili III had several children, ${ }^{52}$ some of them with his last wife Pudu-Heba, others from another woman/other women and born before this marriage. As well known, Pudu-Heba, who came from Kizzuwatna, was the daughter of the priest of Ištar Pendib-Šarri. Her father held a Hurrian name ${ }^{53}$

${ }^{43} \mathrm{He}$ is mentioned in the third paragraph of the so called "Autobiography" of Hattušili III; he might be the same individual, REX[.FILIUS], whose seal is impressed on a cretula from Nişantepe (see Herbordt 2005, 132 no. 111), and also the person who is mentioned among the witnesses of the Aleppo Treaty with Muršili II; see now Devecchi 2010, 13-14. On this name see also Otten 1975, 8.

${ }^{44}$ See lastly Hawkins 2005a, 253-254; Zehnder 2010, 108-109.

45 See Nowicki 1983; Hawkins in print; I thank J.D. Hawkins for having allowed me to read the manuscript of his work.

${ }^{46}$ See also Giorgieri 2000b, 290: "Teššup è la (mia/sua) certezza".

${ }^{47} \mathrm{He}$ was the same person whose other name was Kurunta, se lastly Giorgieri Mora 2010, 138-139 n. 10 with previous literature.

${ }^{48}$ See Salvini 1991, 180.

${ }^{49}$ If we want to use Singer's words, 2006a, 43.

${ }^{50}$ See Cammarosano 2009, 181; Cammarosano 2010.

${ }^{51}$ See Hawkins, in print.

${ }^{52}$ See de Roos 2006, 20-23; van den Hout 1995, 80.

${ }^{53}$ See $§$ 4.4.6.1. s.v. 
and her name too was Hurrian: pud=u-Hebat "Hebat gave birth to her". ${ }^{54}$ Some of Hattušili's children held Hurrian names, whilst others had Anatolian names. Strictly connected with the dynastic names of the royal family are the names of Princes Huzziya and Tuthaliya/Tašmi-Šarruma (on this second name see ultra); the name of Nerikkaili clearly refers to the city of Nerik; the names Tarhuntapiya ${ }^{55}$ and Hannutti ${ }^{56}$ are Hittite; Kurakura ${ }^{57}$ belongs to the oldest Anatolian tradition; ${ }^{58}$ one of Hattušili's daughter received the name Gaššuliyawiya ${ }^{59}$ which had been borne by her grandmother, ${ }^{60}$ that is Muršili II's wife. Hattušili's other children had Hurrian names: Princes Hešni ${ }^{61}$ and Hišmi-Šarruma ${ }^{62}$ (also Evri-Šarruma might be one the king's sons); ${ }^{63}$ Princess Kiluš-Heba ${ }^{64}(k e l=o=\check{z}=$ Hebat "Let Hebat give prosperity"), who married Ari-Šarruma, king of Išuwa and then, after his death, presumably his brother Ali-Šarruma; she was the mother of Ehli-Šarruma, follower of his father on the throne of Išuwa. ${ }^{65} \mathrm{On}$ the basis of KUB 57. 125 obv. 19 (a letter sent by Hattušili III to Ramses II), E. Edel has proposed that the Hittite princess, who married the pharaoh, held the name $\left.{ }^{\mathrm{fd}} \mathrm{IŠTA}\right] \mathrm{R}-n u$ (=Šaušganu), ${ }^{66}$ but since this passage is very fragmentary other readings and interpretations of line 19 are possible. In conclusion, Hattušili's choices for the names of his children are quite eclectic.

54 For the meaning of verb pud- see Wilhelm 2003, 394. A different interpretation of this name is given by de Roos 2006, 19: "Effective is Hepa(t)".

${ }^{55}$ See van den Hout 1998 for the hypothesis that he might be one of Hattušili's sons.

${ }^{56}$ On this prince see van den Hout 1995, 199-203.

${ }^{57}$ Concerning his relationship to Hattušili III, see Klengel 1991, 226; van den Hout 1995, 109-111.

${ }^{58}$ See Zehnder 2010, 47; for other names formed with the reduplication of a bysillabic base see Hoffner 1998, 117.

${ }^{59}$ See Otten 1975, 29; see now Zehnder 2010, 183.

${ }^{60}$ It is presumable that Hattušili was Gaššulayawiya's son, more cautious is Ünal 1974, 44.

${ }^{61}$ Hešni is considered one of Hattušili's sons on the basis of KBo 48. 123, see de Martino in print.

${ }^{62}$ See van den Hout 1995, 131.

${ }^{63}$ See ultra $\S 4.4 .1$. s.v.

${ }^{64}$ On this princess see Singer 1991, 328; de Roos 2005, 211; Zehnder 2010, 188-189.

${ }^{65}$ See de Roos 2005, 215; de Martino 2010c.

${ }^{66}$ Edel 1994, 226-227; see also Beal 2002, 67. 
Arma-Tarhunta, son of Zida (brother of Šuppiluliuma I), was, in all probability, married to a woman, who had the Hurro-Luwian name Šaušgatti. ${ }^{67}$ As well known, Arma-Tarhunta was in charge of the Upper Land at the time of Muršili II, but then he lost the government of this region when Muwattalli II gave it to his brother Hattušili.

The hypothesis that Tuthaliya IV had a second name has been advanced by several scholars. ${ }^{68}$ This name, documented by the seal impressed on the tablet RS 17.159 and now also by an impression from Nişantepe, has been read in different ways. This problem has been also connected to the identity of the individual named BU-Šarruma mentioned in KBo 4. 14, who was identified with Tuthaliya IV. ${ }^{69}$ Now it is clear that BU-Šarruma of KBo 4. 14 cannot be the Hittite king Tuthaliya IV. ${ }^{70}$ Moreover, D. Hawkins, on the basis of the new documents from Nişantepe, has convincingly shown that the second name of Tuthaliya IV was Tašmi-Šarruma, ${ }^{71}$ as S. Alp (1998) had already proposed.

The mother of one of Tuthaliya IV's wives had the name Pattiya; ${ }^{72}$ she is mentioned in the oracular inquiry KUB 22. $70 \mathrm{rev} .13,14,15,66,67^{73}$ that can be dated to the time of Hattušili III / Tuthaliya IV $^{74}$ (see also $§$ 4.4.4. s. v. Heba-muwa). This name is documented also at Nuzi $;{ }^{75}$ its etymology is not sure: it might be connected to the Hurrian verbal root of unknown meaning $\mathrm{pad}^{-76}$ that is recognizable in the name Pada-šarri (Emar) ${ }^{77}$

${ }^{67}$ See van den Hout 1998, 67; Zehnder 2010, 269.

${ }^{68}$ See the literature quoted by Heinhold-Krahmer 2001, who on the contrary (p. 197) considers the signs on the seal impressed on the tablet RS 17.159 as an epithet, following van den Hout's suggestion.

${ }^{69}$ See the literature quoted by Bemporad 2002, 72 n. 6 .

${ }^{70}$ See Singer 1985; Bemporad 2002 (with a different historical reconstruction).

${ }^{71}$ Hawkins in print.

${ }^{72}$ See Hagenbuchner-Dresel 2010, 158 n. 29; see now Zehnder 2010, 246-247.

${ }^{73}$ See Ünal 1978, 84-85, 98-99.

${ }^{74}$ See lastly Carruba 2000, 75; de Roos, 2007, 66.

${ }^{75}$ See Gelb - Purves - MacRae 1943, 112; Cassin 1977, 107.

${ }^{76}$ I wonder if the name Padib-Šarri, documented in a tablet from Tell Brak (Finkel 1988, 85) might be connected to this same root, instead of considering it as a variant of Pantib-Šarri as I. Finkel (loc. cit.) proposes.

${ }^{77}$ See Pruzsinszky 2003, 252 n. 272. 
Tuthaliya IV' sons, Arnuwanda (III) ${ }^{78}$ and Šuppiluliuma (II), bore Anatolian dynastic names. The fragmentary tablet KUB 21. 7 IV 11,79 mentions an individual, "son of Tuthaliya", who has the Hurrian name TulbiLUGAL-ma (=Tulbi-Šarruma); in this same text we find [Šuppilul]iyama, Arnuwanda (1. 9') and [K] uzi-Tešob (1. 11'). I. Singer has proposed that he might have been one of Tuthaliya IV's sons. ${ }^{80}$ The hypothesis that Tuthaliya IV might have chosen, for one of his sons, a name composed with Šarruma is fully reasonable, since this god was his personal protective deity. Lastly we know also the name of a daughter of Tuthaliya IV, that is Ehli-Nikkal (a Hurrian name: $e \dot{g} l=i=N i k k a l$ "Let Nikkal keep safe" $\left.{ }^{81}\right)$, who married Niqmaddu III king of Ugarit. ${ }^{82}$

\subsection{Between Tradition and Innovation}

Hurrian personal names are frequent among the members of the Hittite royal family mostly in three periods: 1) when Kizzuwatna became part of the Kingdom of Hatti; 2) at the time of Muwattalli II; 3) during the reign of Hattušili III.

In the first case - since, as we have already said, it is possible that Tuthaliya I/II's wife was a Kizzuwatnean princess - we may presume that she, her husband Tuthaliya I/II and their daughter Ašmu-Nikkal were responsible for making the Hittite court acquainted with Kizzuwatnean Hurrian deities and culture. ${ }^{83}$

Muwattalli II favoured the south-eastern Anatolian religious traditions and promoted gods and cults of Kizzuwatna. ${ }^{84}$ We do not know if also Queen Tanu-Heba was, in some way, responsible for this; her name shows

${ }^{78}$ See Bemporad 2002, 76-77, for the hypothesis that BU-Šarruma might be the second name of Arnuwanda III and that he might be the person mentioned in KBo 4. 14.

${ }^{79}$ See Stefanini $1962,19,21$, with a different reading of the signs preserved in 1. 11 '.

${ }^{80}$ Singer 2003, 344.

${ }^{81}$ See Giorgieri 2000b, 288.

${ }^{82}$ See Singer 1999, 701-704; Freu 2006, 161; Zehnder 2010, 172.

83 See Miller 2004, 350-356; Taracha 2005, 90-91; Klinger 2010, 165; Yakubovich 2010, 276-277.

${ }^{84}$ See Singer 1996, 192-193. 
that her parents were devoted to the Goddess Hebat and this might suggest an origin of her family from Kizzuwatna.

Pudu-Heba's role in the diffusion of Kizzuwatnean cults is already well known. It is not a coincidence that in these three periods of the history of the Kingdom of Hatti - when ties with Kizzuwatna and more generally with the South-eastern part of Anatolia were established and, afterwards, reinforced members of the Hittite royal family bore Hurrian names.

As we have seen, in some cases a king of Hatti could have a double name, an Anatolian non-Hurrian name and a Hurrian one: ${ }^{85}$ Tuthaliya III/Tašmi-Šarri; Muwattalli II/Šarri-Tešob; Muršili III/Urhi-Tešob; Tuthaliya IV/Tašmi-Šarruma. Following R. Beal, we can suppose that the Hurrian name was an alternative one and not the original name given at the birth of the child and then, at the moment of ascending the throne, discarded in favour of an Anatolian dynastic name. ${ }^{86}$ As D. Hawkins has written, the case of Muwattalli II's "Umarmungsiegel", where his Hurrian name appears inside the royal aedicula, clearly demonstrates that Šarri-Tešob was an alternative official name. ${ }^{87}$ It is true that Urhi-Tešob seems to have used his Hurrian name on seals when he was not yet king and then he preferred the dynastic name Muršili, but we can presume that his will of stressing his legitimacy was the reason why he opted for the latter name after his accession to the throne. ${ }^{88}$

I do not believe that a Hurrian name was given only to that prince who did not have a reasonable chance of ascending the throne, as the case of Urhi-Tešob might suggest, ${ }^{89}$ since both Tuthaliya III and Muwattalli II inherited the throne as fully legitime heirs and according to the will, respectively, of Arnuwanda I and Muršili II.

The choice of Hurrian names for some of the members of the Hittite royal family is a sure signal of the diffusion of Hurrian culture and traditions and of the receptivity of them among the élite of the Hittite society. At the same time, it is true that the Hurrian component of the Hittite world never became prevalent and remained ouside the dynastic ideological tradition of the Hittite kingship: in fact, no heir to the throne of Hatti chose a Hurrian

\footnotetext{
${ }^{85}$ See Beal 2002.

${ }^{86}$ Beal 2002, 67.

${ }^{87}$ Hawkins in print.

${ }^{88}$ See Hawkins in print.

${ }^{89}$ See Beal 2002, 67.
} 
name becoming king. The case of Piyaššili/Šarri-Kušub, son of Šuppiluliuma I, is just opposite, since he used his Hurrian name Šarri-Kušuh when he became king of Kargamiš $;{ }^{90}$ this is a signal that the social and/or cultural dominance of the Hurrian language among the upper levels of the society of Kargamiš was much greater than at Huattuša.

The greatest part of the Hurrian names adopted for the members of the Hittite royal family belongs to the typology of the so called "Satznamen", that are the most diffused and beloved names in the Hurrian societies of the Ancient Near East. ${ }^{91}$ In the case of the Hittite royal family one of the two components of these names is almost always the name of a divinity and the second one is usually a verbal form, more rarely a noun or an adjective.

The Hurrian feminine names of the Early Empire, Nikkal-madi, AšmuNikkal, Tadu-Hुeba and Šatandu-Hुeba, show that Nikkal and Hebat were particularly venerated by the royal family of that time. The cult of Nikkal $(<$ NIN.GAL) ${ }^{92}$ was favoured by Queen Nikkal-madi ${ }^{93}$ and we can suppose that this Goddess was venerated in Kizzuwatna, from where this queen presumably came, as it was also in several regions of Syria. ${ }^{94}$ Also the cult of Hebat ${ }^{95}$ was introduced from Kizzuwatna in this same time and then developed during the reign of Hattušili III. ${ }^{96}$

Hurrian verbal roots and nouns presented in the names Nikkal-madi, Ašmu-Nikkal, Tadu-Heba and Šatandu-Heba are documented also in other Hurrian names from different region of the Ancient Near East; ${ }^{97}$ some of these names might have imitated those that were common at the court of

${ }^{90}$ See del Monte 2008, 119 and n. 59. It is true that in the accord between the king of Hatti (presumably Muršili II) and the king of Kargamiš (KBo 1. 28) the latter bears the name Piyaššili, but this is an act issued by the Hittite king and it concerns the status of his brother and his relation to the tuhkanti (see Mora 1993). On the names of the other kings of Kargamiš see $\S 3$.

${ }^{91}$ See Wilhelm 1998, 122-125.

${ }^{92}$ See Haas 1994, 375.

93 See Imparati 1979.

${ }^{94}$ See Weppert 2000; de Martino 2009, 257

95 Concerning the origin of the cult of this deity in Syria see Archi 1994, 249252.

${ }^{96}$ See Haas 1994, 385-386.

${ }^{97}$ For madi see Draffkorn 1958, 90; Pruzsinszky 2003, 236, 244, 251; for tadsee Gelb - Purves - MacRae 1943, 263; Pruzsinszky 2003, 248; for ažm- see Gelb Purves - MacRae 1943,206; Draffkorn 1959, 26; Pruzsinszky 2003, 227, 232; for šad- (without the suffix -an-) see Gelb - Purves - MacRae 1943, 252; Draffkorn 1959, 100; Dinçol - Dinçol - Hawkins - Wilhelm 1994, 102 n. 78. 
Mittani, as for example Kelu-Heba (it was borne by Šuttarna II's daughter) or Tadu-Heba (Tušratta's daughter). Despite this, feminine names composed with Nikkal and Hebat are a peculiar trait of the Hurro-Anatolian onomasticon; in fact, Hurrian personal names with Nikkal are unusual and those with Hebat are diffused mostly in Anatolia and in Syria. ${ }^{98}$ They might have belonged to the tradition of Kizzuwatna; unfortunately we do not know much of that tradition ${ }^{99}$ and, therefore, this remains only a hypothesis, but it can be supported by the fact that also Pudu-Heba, who came from Kizzuwatna, had a similar name.

Masculine names are composed mostly either with Tešob (at the time of Muwattalli II) or with Šarruma (at the time of Hattušili III/Tuthaliya IV). Some of these names, as Tulbi-Tešob ${ }^{100}$ or Urhi-Tešob, ${ }^{101}$ are documented also in texts of other regions of the Ancient Near East; on the contrary, a name as Ulmi-Tešob is unusual, even if the element ulmi is present in other names as for example Kirib-ulmi, ${ }^{102}$ Ulmi-adal and Ulmi-Tilla. ${ }^{103}$

In conclusion, the whole Hurrian onomasticon of the royal family of Hatti moves along the line of the tradition as the preference for "Satzanamen" shows, even if sometimes new names appear, but we cannot exclude that they were already in use in Kizzuwatna and belonged to the onomastic patrimony of this region.

${ }^{98}$ See Trémouille 1997, 233-237.

99 The names of the kings of Kizzuwatna have not yet been investigated in depth; the onomasticon of the royal house of this country seems to be as eclectic as the one of the Hittite royal family; Išputahšu contains the element -aȟ̌ u that is present in names documented in the Kültepe texts and belongs to the oldest Anatolian tradition (see Zehnder 2010, 73-74); in the name Pariyawatri the Cun.Luw. word pariyan is recognizable (see Zehder 2010, 37-38); Eheya is a Hurrian name (Eh(h)iya is documented also at Nuzi, see Gelb - Purves - MacRae 1943, 41; Cassin 1943, 40, and at Alalah, see Draffkorn 1959, 27); Pa/illiya might be Hurrian (from the verbal root pal- ?); Šunaššura has been connected to the Indo-Aryan Mittanian onomasticon (see Goetze 1940, 7; Gelb - Purves - MacRae 1943, 260).

100 See Pruzsinszky 2003, 251 n. 265.

101 See Gelb - Purves -MacRae 1943, 166-167; Cassin 1977, 160; Wilhelm $1998 \mathrm{a}, 124$

${ }^{102}$ See Salvini 1991, 180

${ }^{103}$ See Gelb - Purves - MacRae 1943, 162, 271; Cassin 1977, 155. 


\section{KINGS AND RULERS OF SUbORDINATED COUNTRIES}

If we look at the royal dynasties of the countries subordinated to Hatti, the members of the cadet dynasty of Kargamiš favoured Hurrian names: all the kings of this country bore Hurrian names ${ }^{104}$ (Šarri-Kušuh = Piyaššili; IniTešob; Talmi-Tešob; Kuzi-Tešob), with the only exception of Šahurunuwa. This name has been interpreted by some scholars as Hurrian and connected to the word še/uguri ${ }^{105}$ "life", ${ }^{106}$ but the changing of the first vowel $e / u>a$ has not been explained. In my opinion this name might be Anatolian; it sounds similar to the Hittite geographical names in $-(u) w a$ and it might come from a place name. ${ }^{107}$ It is interesting to note that Šahurunuwa presumably had a Hurrian second name [X-]Šarruma (as the Annals of Muršili II, ninth year, witness) ${ }^{108}$ if we accept the hypothesis that XŠarruma really was the second name of Šahurunuwa, we may suppose that he was born when his father was not yet king of Kargamiš and that at his birth he had received an Anatolian name. His role, as king of Kargamiš, pushed him to choose a Hurrian second name, as his father did. His followers, on the contrary, held only Hurrian names. ${ }^{109}$

Moving to the other cadet dynasty, the one ruling on Halpa, we know the names of the kings Telepinu, Talmi-Šarruma, ${ }^{110}$ Halpa-ziti; we see that among the two followers of Telepinu, the first one chose a Hurrian name, and the second a Luwian one, but with explicit mention of his city, Halpa.

104 See Beal 2002, 66; van Soldt 2003, 685 (with reference not only to the kings, but also to other members of the royal family).

${ }^{105}$ See for example Mascheroni 1984, 162.

${ }^{106}$ See André-Salvini - Salvini 1998, 16.

${ }^{107}$ It might be related to the name of the river Sagur that flows near Kargamiš; I thank I. Singer for this suggestion.

${ }^{108}$ See the literature quoted by Miller 2007, 134 n. 29; see now also Devecchi 2010, 14 n. 51.

${ }^{109}$ For the names of other members of the royal family and princes of Kargamis see Mora 2004; Mora 2008.

110 See Miller 2007, 137 n. 30: this scholar, rightly, excludes that Halpahi (mentioned in "Muršili II's Dictate to Tuppi-Tešob's Syrian antagonists", KUB 19. $31+$ ) might be the second name either of Telipinu or of Talmi-Šarruma. 
Concerning other subordinated countries, all the kings of Išuwa known to us, that is Ari-Šarruma, Ali-Šarruma and Ehli-Šarruma had Hurrian names; we do not know anything about the origin of this royal family, that appears in the sources at the time of Hattušili III and was strictly bound to the Hittite court. ${ }^{11}$

In Amurru Hurrian names became trendy after the passage of this country under Hittite control and Aziru's followers held Hurrian names, ${ }^{112}$ so imitating the rulers of Kargamiš. ${ }^{113}$ Šaušga-muwa, who is commonly considered the last king of Amurru, ${ }^{114}$ bore a name composed with the Hurrian divine name Šaušga and the Luwian-Hittite element $-m u w a ;{ }^{115}$ this hybrid name is very well suited for a prince (and then king) of Amurru, who was son of a Hittite princess. ${ }^{116}$

The situation of Ugarit is completely different and Hurrian names were not adopted, with the only exception of Ar-Halba. ${ }^{117}$

Western Anatolia was not affected by the mode of the Hurrian names and none of the rulers of Western Anatolian countries had a Hurrian name. Lastly let us consider the kingdom of Tarhuntašša: the hypothesis has been recently advanced that the individual named Šaušga-Runtiya might be Kurunta's son or at least a member of his family. ${ }^{118}$ This name ${ }^{119}$ appears on

${ }^{111}$ See lastly de Martino 2010c.

112 See Singer1991, 182-184; see also van Soldt 2003, 686.

${ }^{113}$ As I. Singer $(2010,275)$ writes, "sometimes in the Early Iron Age the kings of Amurru again bore Semitic names".

${ }^{114}$ According to I. Singer (2010), he was followed by King Mahhaza, whose name might be Hurrian, see Singer 2010, 275 n. 9.

115 See n. 163.

116 See Singer 1991, 172. Moreover we have to mention Syrian rulers such as Tagu(wa) and Agi-Tešob (Niya), Tagib-Šarri (Ugulzat), Šarrupše (Nuhḩašše), whose names are Hurrian.

${ }^{117}$ See Singer 1991, 183-184; Singer 1999, 637-638; van Soldt 2003, 702-703.

${ }^{118}$ See Marizza 2006, 166-168.

119 This same name is also in the tablet KUB 50. $72+$ KBo 53. 107 IV 2' (see Lefèvre-Novaro - Mouton 2008, 33- 36) that deals with mantic inquiries through the technique of lecanomancy; since in the same passage of this text also Nerikkaili (IV 2') is mentioned, we can presume that Šaušga-Runtiya of this text is Kurunta's son and that the inquiry deals with members of the royal family. For Šaušga-Runtiya in other Hittite cuneiform texts see Marizza 2006, 166-168: it is interesting to note that also in one of the texts quoted by Marizza, KUB 5072 I 1'-2', Šaušga-Runtiya and Nerikkaili are mentioned together; see also KUB 26. 18 9'-10' (Marizza 2006, 167). 
the impressions of several seals; ${ }^{120}$ he is prince, Chief Scribe, Chief of the Palace Attendants and, in the seal impressions from Nişantepe nos. 376 and 377, "Prince of the city (land?) of Tarhuntašša". ${ }^{121}$ Šaušga-Runtiya appears also in the inscription of Köylütolu Yayla, where he bears the titles prince and Chief of the Palace Attendants; ${ }^{122}$ as D. Hawkins $(2005,271)$ writes, Šaušga-Runtiya's connection with Tarhuntašša may explain the fact that he is mentioned in an inscription posed on the Hatti - Tarhuntašša frontier. The personal name Šaušga-Runtiya is a hybrid that contains two divine names, that of the Hurrian deity Šaušga and that of the Luwian Stag-God Kurunta/Runtiya, ${ }^{123}$ and fits very well the Hurro-Luwian composed cultural character of South-eastern Anatolia.

${ }^{120}$ See Hawkins 2005a, 271.

${ }^{121}$ See Herbordt 2005, 181; Hawkins 2005a, 271. Following D. Hawkins (2005, 271) we can distinguish among several different individuals all named ŠaušgaRuntya: 1) the "Prince of Tarhuntašša"; 2) the Scribe; 3) the EN URU(-LIM); see here also $§ 4.4 .8$ s.v.

122 See Ehringhaus 2005, 47-48.

${ }^{123}$ See Popko 2007, 66-68. 



\section{Hurrian Personal Names In the Hittite Society}

\subsection{Old Kingdom}

During the Old Kingdom ${ }^{124}$ Hurrian personal names were not borne by members of the Hittite royal family ${ }^{125}$ or by state officials. The very few Hurrian names that we find in Hittite texts of this period refer only to foreign people, as for example Tuniya (=Tunip-Tešob), ruler of Tigunani, documented in the well know letter sent to him by Hattušili I. ${ }^{126}$ The Hittite tablet KBo 3. $60^{127}$ mentions a military leader named Kaniu, who commanded the soldiers of Surra, presumably located in the area of the Tur Abdin. ${ }^{128}$ The name Kaniu might be Hurrian and it might be linked to the root kan- that appears in a Hurrian name (Kanik-evri) documented by the habiru prism of Tigunani ${ }^{129}$ (VII 22). ${ }^{130}$

\subsection{Early Empire}

In the Hittite society of the Early Empire Hurrian personal names were quite an exclusive prerogative of the members of the royal family. In fact, the greatest part of the Hurrian names documented in Hittite sources of this time belong either to members of the royal family or to foreigners, who moved to Hatti or are mentioned in Hittite texts. Only very few Hurrian names refer to people working for the Hittite administration.

${ }^{124}$ On Hurrian personal names in the Kültepe texts see lastly Wilhelm 2008.

${ }^{125}$ Concerning BU-Šarruma of the Offering Lists see de Martino 2010b, 130131.

126 See Salvini 1996a, 107-116; see now also Hoffner 2009, 75-80 with literature.

127 See lastly de Martino 2002; Forlanini 2004, 256, 269 n. 36 (this scholar believes that the text refers to the time of Labarna I).

${ }^{128}$ See de Martino 2002, 79-80.

${ }^{129}$ See Salvini 1996a, 32.

130 See Richter 1998, 133 n. 33; in this same text there is also the name Kaniu (VII 1), see Salvini 1996a, 30. On the name Kaniu see now also Zehnder 2010, 93. 
Foreigners who were active in Huatti in the Early Imperial Age belong to different professional groups:

a) A tablet in Hurrian from Kayalıpinar, that describes a military expedition to north-western Syria, mentions three individuals who have Hurrian names: Ehli-Tenu, Ilī-Šarruma, Ehlib-Adda; ${ }^{131}$ they might have been Kizzuwatnean generals or military officials, who participated in a campaign of Tuthaliya III. ${ }^{132}$ We can put forward the hypothesis that Tuthaliya III might have hired Kizzuwatnean soldiers or military leaders during his campaigns to Syria.

b) In the Early Empire several ritual texts of Kizzuwatnean and Syrian tradition were collected in the Hittite archives. As J. Miller writes, ${ }^{133}$ these texts could be attributed to Hittite scribes who might have either copied them from the original Kizzuwatnean tablets or written them interviewing local experts of rituals during Tuthaliya I/II's expeditions to south-eastern Anatolia. Otherwise these compositions could be the product of Kizzuwatnean experts active in the Kingdom of Hatti. These experts of

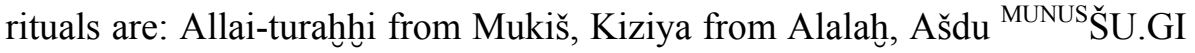
${ }^{\text {URU }}{ }_{\text {Hurlašs }}{ }^{134}$ Madi, Ammihatna, Tulbi(ya), Paba-nigri and Naniyanni from Kummani, Šalašu from Kizzuwatna; ${ }^{135}$ with the only exception of Ammihatna, ${ }^{136}$ all the others bear Hurrian names.

${ }^{131}$ See Wilhelm 2006, 233-236; Rieken 2009, 130-135.

132 See de Martino 2010b, 135; I am indebted to G. Wilhelm for the information that this text refers to events of the time of Tuthaliya III.

${ }^{133}$ Miller 2004, 506-511.

${ }^{134}$ On this expression see Görke 2010, 273-277.

135 Some ritual texts have been attributed to the ritualist ${ }^{\mathrm{f}} \mathrm{Ambazzi}$ (see Christiansen 2006); this personal name is interpreted by Zehnder 2010, 113, as Hurrian; this scholar connects it to the Hurrian verb $a m=b$ - "to be on fire, to burn". A name formed with such a verb seems to me quite strange; moreover I am not able to find a Hurrian explanation for the second element -azzi. Since Ambazzi rituals seem to belong to Western Anatolian tradition (see Christiansen 2006, 326) and a Hurrian etymology of this name cannot be recognized for sure, I have excluded it from the present catalogue.

136 The personal name Ammi-hatna has been interpreted as Semitic, see Strauss 2006, 280 and n. 189; differently Zehnder 2010, 112, has proposed that this name might be Hurrian, even if a clear Hurrian interpretation cannot not be given. 
c) Presumably ${ }^{137}$ two experts of medicine, who have Hurrian names, Agiya and Hudubi, exercised the profession of physician in Hatti in this same period.

d) Ehal-Tešob, diviner from Aleppo, "author" of rituals, might have lived between the end of the Early Empire and the beginning of the Imperial Age. ${ }^{138}$

e) Hurrian personal names (Agiya, Ali-p/wašu, Ehalte, Hurlanni, Nani) were held by some of the inhabitants of the region of Išmeriga, that was close to Kizzuwatna, as it is documented in the agreement signed by Arnuwanda I with the people of this country. Also Kumarbi, who is mentioned in KBo 16. 42 rev. 18'; 20', might refer to an inhbabitant of an Eastern Anatolian country (see $\S 4$ 4.4.8. s.v.).

As we have already said, a peculiar situation can be recognized in the onomasticon of Ortaköy/Šapinuwa. Unfortunately only very few of the texts coming from this site have been published and we lack any precise information about all the personal names documented in them and also about the content of these texts, so that it is impossible to define the percentage of Hurrian names and to conduct a prospographic analysis. From the available tablets we know that some of the functionaries, who were active in the administrative structures of this city, had Hurrian names, as for example Agiya, Hubidi (who are senders of letters), ${ }^{139}$ or Mušu (who is the recipient of a letter sent by the king). ${ }^{140}$

Since the letters from Šapinuwa are not yet available, we do not know if this Hubidi might be the same individual (AMAR-ti) ${ }^{141}$ who has written the tablet in Hurrian KUB 32. $19+\left(\mathrm{ChS} \mathrm{I} / 141 ;{ }^{142}\right.$ for the colophon see IV 4950), ${ }^{143}$ Prayer of Tadu-Heba to Tešob for the Well-being of Tuthaliya

\footnotetext{
${ }^{137}$ See $\S 4.4 .7$.

${ }^{138}$ See $\S$ 4.4.6.3.

139 See Ünal 1998, 31.

140 See Ünal 1998, 40-41.

${ }^{141}$ See Mascheroni 1984, 157; see also Marizza 2007, 69.

${ }^{142}$ See also Singer 2002b, 43-44.

${ }^{143}$ The tablet is MH, see Košak-web site.
} 
III/Tašmi-Šarri. ${ }^{144} \mathrm{He}$ is also the scribe of the $\mathrm{MH}$ purification ritual KBo 22. $129(+) 129 \mathrm{a}^{145}$

We cannot explain why only in Šapinuwa in the Early Empire there were people with Hurrian names active in the administration of the state. Since Šapinuwa was a royal residence of Tuthaliya III, we might in some way link the predilection of the royal family for Hurrian names to the presence of Hurrian or Hurrianized people in this city. We do not know whether these functionaries came from Kizzuwatna or belonged to a local Hurrian community, that until that time had remained excluded from the ranks of the Hittite administration.

We have to stress that among the names of these officials we find two hypocoristicon names ${ }^{146}$ (Agiya and Mušu) and one name derived from that of an animal (Hubidi "young bull"), that is names belonging to a different typology, we might say less noble than that of the names held by the members of the royal family of this same time.

The presence of other individuals who bore Hurrian names is only sparsely documented; one of six workers, assigned to the royal palace in the Maşat tablet HKM 100 obv. 11', ${ }^{147}$ bears the name Purazi. This name, that contains the word pura (connected to pura $=$ me "slave"), ${ }^{148}$ might refer to his social condition. A man by the name Agiya belongs to the personnel of a household in the land grant KBo 5.7 obv. $24 ;{ }^{149}$ in this same text a woman, Azziya, is listed among the personnel of a "house" (rev. 28). ${ }^{150}$

The woman Yaru-Heba, who takes part in the ritual KUB 60. 121 (rev. $18)^{151}$, might belong to the entourage of the royal family.

Lastly, an individual named Zuzzu is one of the witnesses of the land grant, issued by Huzziya II, LS 2 (rev. 11); he has the title uriyanni. ${ }^{152} \mathrm{He}$ is the same dignitary who is mentioned in the fragmentary land grant, KBo 32.

\footnotetext{
${ }^{144}$ See de Martino 2005, 295.

${ }^{145}$ See Groddek 2008, 120-121.

${ }^{146}$ Or "shortened names", see Cohen 2010.

${ }^{147}$ See del Monte 1995, 98-99.

${ }^{148}$ See also names such as Puraman and Puramzi, see Richter 2005, 152-153.

${ }^{149}$ See Riemschneider 1958, 344.

${ }^{150}$ See Riemschneider 1958, 350-351.

${ }^{151}$ See Popko 1991.

152 See Riemschneider 1958, 340, 358-359; see also Pecchioli Daddi 2010.
} 
187 rev. 5'-6', since also in this tablet he has the title uriyanni and is mentioned together with Marašša. A scribe ${ }^{153}$ by this name has written the land grant LS 2 (rev. 12), ${ }^{154}$ that bears the impression of the seal of Huzziya II. ${ }^{155}$ Although a name Zuzu is documented at Mari ${ }^{156}$ and at $\mathrm{Nuzi}^{157}$ and it might be connected to the Hurrian word zuzuhe $(z u z=o=\dot{g} e)$, that is documented in a Quadrilingual Vocabulary from Ugarit, ${ }^{158} \mathrm{I}$ am inclined to consider it as an Anatolian "Lallname"159 and not as Hurrian, in consideration also of the fact that we do not find other high dignitaries bearing Hurrian names in this period.

\subsection{Imperial Age}

4.3.1. In the course of the $13^{\text {th }}$ century Hurrian personal names became more and more popular among the élite of the Hittite society, even if they remained a minority inside the Hittite onomasticon. The peculiar character of the Hittite sources, which consist only of official texts, and the lack of private archives do not allow an investigation in all the components of the society, since they give information only on those individuals who were somehow involved in the administration or in the cult.

Hurrian personal names seem to in vogue at the time of Hattušili III and Tuthaliya IV, whereas they were not diffused among functionaries and dignitaries at the time of Šuppiluliuma I and Muršili II. Hurrian names documented in Hittite texts refer mostly to men, but this is due in part to the fact that men were more involved in official roles and in professions and therefore more visible in Hittite sources. We find some women mentioned in texts of the time of Hattušili III, such as Aru-Heba, Ašnu-Heba, Heba-muwa, Heba-piya: they seem to be involved in the life of the court and be close to the queen. Presumably they were at the service of Pudu-Heba; the fact deserves attention that their Hurrian or Hurro-Hittite names are composed with the divine name Hebat, a Goddess worshipped by the queen herself.

\footnotetext{
153 See Mascheroni 1984, 164-165.

${ }^{154}$ See Riemschneider 1958, 358-359.

${ }^{155}$ See van den Hout 2009, 82 and n. 69.

156 See Sasson 1974, 373.

${ }^{157}$ See Gelb - Purves - MacRae 1943, 182; see also Beal 2003, 19.

${ }^{158}$ See Huehnergard 1987, 26, 54; van Soldt 1990, 731.

${ }^{159}$ See Zehnder 2010, 45-49.
} 
The choice of Hurrian names within the same family through two or more generations is attested in some cases: the scribe Hešni was son of Naniya (the latter presumably was the same individual who had the title patili in the seal impression no. 279 from Nişantepe); ${ }^{160}$ Tehi-Tešob, Hittite royal messenger and active in Syria at the time of Hattušili III, might have been the son of the scribe Ibizzi, who wrote the tablet KBo 10. 47, Hittite version of the poem of Gilgameš. ${ }^{161}$

In spite of this, if we look at the families of the élite of the Hittite society, that we know for some generations, we see that the same eclectic character of the onomasticon of the Hittite royal family at the time of Hattušili III can be recognized also among them. As an example I present here the case of the family of Mittana-muwa: he was GAL DUB.SAR ${ }^{\text {MEŠ }}$ Chief Scribe at the time of Muršili II and Muwattalli II. ${ }^{162}$ His name clearly refers to the country of Mittani ${ }^{163}$ and we can suppose that his family was in some way connected to the Hurrian tradition and culture. ${ }^{164}$ Considering the presumable origin of Mittana-muwa and the fact that Hurrian names were in vogue during the Late Hittite Empire, we would expect that only Hurrian names had been adopted for the members of this family; on the contrary, it seems that eclecticism (that is Anatolian and Hurrian names) was the trend also among the higher levels of the Hittite society. In fact we know the names of five of Mittanna-muwa's children: Ali-ḩešni, Puranda-muwa, UR.MAH-ziti /Walwa-ziti, ŠEŠ-zi /Nani(n)zi) and Adduwa. ${ }^{165}$ The first one of these names is Hurrian, that is Ali-hešni; ${ }^{166}$ Puranda-muwa ${ }^{167}$ is a hybrid (as the name of his father Mittanna-muwa), that contains the Hurrian form of the name of the river Euphrates, that is Purandi, and the Anatolian element -muwa. ${ }^{168}$ The names of the other children of Mittanna-muwa do not belong to the Hurrian tradition. L. Mascheroni (1984, 161-162) wrote that Naninzi

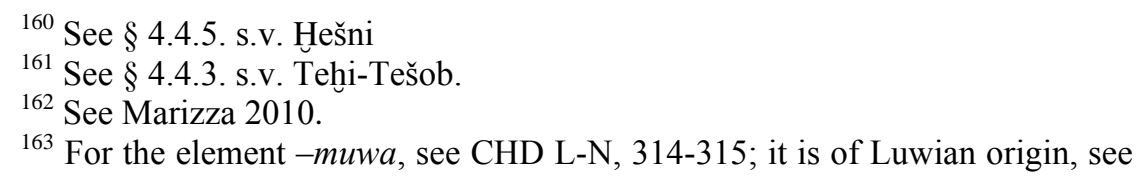
Kloekhorst 2008, 590; Zehnder 2010, 85.

${ }^{164}$ See lastly Doğan-Alparslan 2007, 251.

165 See Doğan-Alparslan 2007, 250.

${ }^{166}$ The first element of this name can be connected to the Hurrian verb al- "to say", see de Martino - Giorgieri, 2008, 52-53. The second element is documented as a personal name, Hešni, and it can come from the same stem from which the word hišni (KBo 24. 69 II? 6'; KUB 27. 37 II? 2') comes.

${ }^{167}$ See now Zehnder 2010, 66.

${ }^{168}$ See n. 163. 
might be Hurrian; presumably she connected this name to Naniya, which is documented at Nuzi, ${ }^{169}$ Alalah ${ }^{170}$ and also in the kingdom of Hatti (see 4.4.6.1 s.v. Naniya). In reality, the logographic writing ŠEŠ-zi corresponds to Nani(n)zi ${ }^{171}$ and this name can be connected to the Luwian word nāna/i"brother". ${ }^{172}$

Walwa-ziti, who as his father Mittanna-muwa was Chief Scribe, had two sons, Talmi-Tešob and Hulanabi: the first one held a typical Hurrian name; the second one had a name that might be interpreted as the name of the river Hulana plus the Hurrian suffix of the genitive $-v e,{ }^{173}$ that is a formation analogous to Kumarbi $(<$ Kumar $=v e) .{ }^{174}$ The aspect of this name is Hurrian, but the river Hulana, that M. Forlanini $(2008,60)$ proposes to identify with the Porsuk Çay, is in Western Anatolia and does not have anything to do with the Hurrians.

Another son of Mittanna-muwa, Ali-ḩešni married ${ }^{\mathrm{f}}$ Tarhunta-manawa, who might have been the daughter of Šahurunuwa, ${ }^{175}$ a very powerful and wealthy personage of the time. ${ }^{176} \mathrm{We}$ know the names of two of the children of this couple: Tulbi-Tešob and Kuwalana-ziti. ${ }^{177}$ The first one of these names is typically Hurrian; the second one is Anatolian.

4.3.2. Concerning the professions of those individuals who held Hurrian names (see $\S 4.4$. for a more detailed presentation), we find several officials involved in the administration at different levels, as for example, Evri-

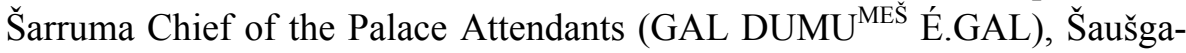
Runtiya City-Lord (EN URU ${ }^{L I M}$ ) of Hatti, ${ }^{178}$ Šaušga-muwa City-Lord (EN $\mathrm{URU}^{L I M}$ ) and scribe, Tagi-Šarruma Cup-bearer, Talmiya Golden Page ( ${ }^{\text {LÚ KUŠ }}$.GUŠKIN), Talmi-Tešob Chamberlain (LÚ ŠÀ.TAM), Ali-ḩešni

${ }^{169}$ See Gelb - Purves - MacRae 1943, 103.

170 See von Dassow 2008, 293.

${ }^{171}$ See van den Hout 1995, 182 n. 332.

172 See Zehnder 2010, 77; on nāna/i- see Rieken 1999, 262; Poetto 2010, 272273; differently H.A. Hoffner Jr. (1998, 118) reads ŠEŠ-zi as Nanazi and interprets it as a name based on the divine name Nana.

${ }^{173}$ See Mascheroni 1984, 157.

${ }^{174}$ See Wilhelm 1994, 318.

175 See Imparati 1974, 47-49.

${ }^{176}$ See van den Hout 1995, 151-154.

${ }^{177}$ Marizza 2006, 165-166; Marizza 2010.

178 And also scribe? See the seal from Nişantepe nos. 379-380, see Herbordt 2005, 182 
LÚhalipi, Šaušga-piya Overseer of the Seal Cutters (UGULA LÚ ${ }^{\text {MEŠ }}$ BUR.GUL), Ašmi-Šarruma, Ehli-Kušuh and Ehli-Šarruma, who seem to have been supervisors in the control of movements of goods.

We know two high dignitaries who had Hurrian names, Pendi-Šarruma and Talmi-Tešob (see $\S$ 4.4.2. s.vv.). According to the seal impressions from Nişantepe nos. 322-326, ${ }^{179}$ Pendi-Šarruma was Chief Scribe, ${ }^{180}$ Chief of the Palace Attendants ${ }^{181}$ and prince. He might be the same individual ${ }^{182}$ who was the sender of the letter RS 94.2523, that is the companion letter of the one sent by the Hittite king (presumably Šuppiluliuma II), RS 94.2530; the receiver of both letters was Ammurapi King of Ugarit. ${ }^{183}$ In the tablet RS 94.2530 Pendi-Šarruma has the titles tuppanura huburtinura, Great Scribe and Chief of the Palace Attendants (?) ${ }^{184} \mathrm{He}$ might have been also the same person who has the titles prince and Chief of the Chariot Drivers ${ }^{185}$ $\left(\right.$ MAGNUS.AURIGA $=$ GAL KARTAPPU ${ }^{186}$ ) in the seal impression from Nişantepe no. $327 .{ }^{187}$ All these documents might refer to the different stages of the career of the same official. Talmi-Tešob, Chief of the Chariot Drivers, acts as witness in the treaty of Tuthaliya IV with Kurunta (IV 38) and in KUB 26. 43 (rev. 31[); he is mentioned also in the letter sent by Ini-Tešob of Kargamiš to Ibiranu of Ugarit, RS 17.289 (11. 6-7). The position of Chief of the Chariot Drivers was very high in the Hittite hierarchy and it not necessarily concerned military activities on the field, but it might have been an honorific one. ${ }^{188}$

${ }^{179}$ See Herbordt 2005, 171-172; Hawkins 2005a, 268.

180 See also the fragmentary seal impression SBo II 68 (where Mascheroni 1984, 152, reads [Ma]ti-Šarruma), see Marizza 2006, 168 n. 148.

181 For the interpretation of the Hier. Title MAGNUS.DOMUS.FILUS as equivalent to the Cun. GAL DUMU ${ }^{\mathrm{MES}}$ É.GAL see Hawkins 2005a, 304.

${ }^{182}$ See Singer 2006b, 244.

${ }^{183}$ See Lackenbacher - Malbran-Labat 2005.

184 See Singer 2006b, 244-245, for the equation of the expression tuppanura huburtinura and, respectively, the titles MAGNUS.SCRIBA and MAGNUS. DOMUS.FILIUS; moreover see Herbordt 2005, 97, for the interpretation of the Hier. title MAGNUS.DOMUS.FILIUS as equivalent to Cun. GAL DUMU.É.GAL.

${ }^{185}$ So Lackenbacher - Malbran-Labat 2005, 240; Singer 2006b, 244; Marizza 2006, 169; differently Hawkins 2005a, 268.

${ }^{186}$ See Hawkins 2005a, 302.

${ }^{187}$ See Herbordt 2005, 172.

${ }^{188}$ See Beal 1992, 450. 
Two Hittite royal messengers bore Hurrian names. Teli-Tešob was Hittite messenger at the court of Ramesses II; ${ }^{189}$ he was the same official who was the owner of the seal, the impression of which is preserved on the tablet from Ugarit RS 17.137 (Ugaritica III, 39-40, 135-137). On this same tablet there is also the impression of the seal of Tehi-Tešob, who was another Hittite ambassador. Tehi-Tešob might have been the son of the scribe Ibizzi.

Several scribes with Hurrian names are known from the Hittite texts: Alihhinini son of Zuwa, Hešni son of Naniya, Ibizzi, Kuzi-Tešob, Pendi-šena, Šaušga-muwa, Šaušga-Runtiya, Tadikkanna, Talmi-Tešob, Tehup-šeni. Pendi-Šarruma and Tagi-Šarruma have the title Chief Scribe.

Some of these scribes are involved in the production of texts of Hurrian or Syrian tradition, as for example Ibizzi, who is the scribe of KBo 10. 47, Hittite version of the Poem of Gilgameš, that might derive from the Hurrian version; ${ }^{190}$ Kuzi-Tešob, who is the scribe of omina of Syrian tradition; Talmi-Tešob is the scribe of two tablets of the hišuwa festival (KBo 15. 37] and KBo 35. 260[); Tehub-šeni who is the scribe of the tablet KUB 55. 59, that belongs to the group of the Hurrian lists of offerings for Tešob and Hebat (ChS I/3-2).

Not all the scribes with Hurrian names are specialists only of texts related to the Hurrian language and tradition; for example Hešni is the scribe of the tablet KUB 44. 24, festival for a tutelary deity, ${ }^{191}$ and also of one of the tablets of the nuntarriašha festival, KUB 25. 10.

Concerning the cult, we know some priests who had Hurrian names, as Agiya and Hesni. Naniya was patili priest; patili priesthood presumably belonged to the Hurrian tradition, ${ }^{192}$ even if not every patili priest had a Hurrian name; in fact we know, for example, another patili who had the Anatolian "Lallname" Lullu. ${ }^{193}$ Manniya is a singer from Ankuwa. Experts of rituals are Nikkal-uzzi, Šabšušu and Ummaya.

${ }^{189}$ See lastly Pernigotti 2010, 97-98.

190 See Klinger 2005.

191 See MacMahon 1991, 233-234.

192 See CHD P 3, 246, 383-384; Taggar-Cohen 2006, 177. See also Strauss 2006, 88 .

${ }^{193}$ See CHD P 3, 246; Lullu is an Anatolian Lallname, see lastly Zehnder 2010, 46 n. 69. 
Lastly, regarding the lower levels of the Hittite society, some Hurrian personal names are documented also for individuals mentioned, for example, as members of households, as workers and servants.

\subsection{Hurrian Personal Names: Sociological Distribution}

In the detailed examination of Hurrian personal names that follows, I have inserted the names borne by individuals (not members of royal families), who could be studied concerning their position inside the Hittite society. I have organized this presentation selecting various professional groups: 1. State officials and dignitaries; 2 . Army; 3 . Royal Messengers; 4. Palace personnel and people living at court; 5. Scribes; 6. Cult (6.1. Cult personnel; 6.2. "Authors" of rituals; 6.3. Diviners); 7. Experts of medicine; 8. Other or unknown professions. 


\subsubsection{State Officials and Dignitaries}

Early Empire:

Agiya:

$\mathrm{He}$ is the sender of letters ${ }^{194}$ of the archive of Ortaköy/Šapinuwa addressed to Purra. ${ }^{195}$

This is a very common Hurrian personal name; it is a hypocoristicon name from the verbal root $a g-{ }^{196}$ that means "(a God) has raised (the child) up".

AMAR-ti (= Hubidi):

He too is the sender of letters ${ }^{197}$ of the archive of Ortaköy/Šapinuwa addressed to Purra.

This name belongs to the "Theriophore Namen", since the Hurrian word hubidi means "calf". 198

Mušu:

He is one of the three receivers of a letter sent by the king (Çorum 21-890). ${ }^{199}$ A. Ünal $(1998,43-44)$ proposes to restore the name of Mušu also in the second line of the letter Çorum 21-12-90. ${ }^{200}$

194 See Ünal 1998, 31 with previous literature.

195 This name, that Ünal considers Hurrian, might be Kassite as Richter 1998, 126 , proposes.

${ }^{196}$ See de Martino - Giorgieri 2008, 29-36, with previous literature.

${ }^{197}$ See Ünal 1998, 31 with previous literature.

198 See now Richter 2010, 523. 
I agree with Marizza $(2007 b, 157)$ that Muššu of some land grants of the time of Hantili II is another person in consideration also of the different writing of his name $(M u-u-u \check{s}-\check{s} u)$.

This name comes from the verb $m u z^{-201}$ which is very productive in Hurrian onomasticon. ${ }^{202}$

Imperial Age:

Ali-hูešni:

$\mathrm{He}$ is one of Mittanna-muwa's sons and the son-in-law of Šahurunuwa $^{203}$ (time of Hattušili III/Tuthaliya IV); presumably he is the same individual who is mentioned in KBo 4. 12 Vo 6 as ${ }^{\text {LÚ halipi. }}{ }^{204}$

This name is composed with a verbal form $a l=i(=b)$, that might come from the verb al- "to say, to tell", ${ }^{205}$ and with the word he/ižni that is documented for example in KBo 24. 69 (ChS I/5 84) II 6'; KUB 27. 37 (ChS I/5 85) II? 2'. For the name Hešni see here $\S 4.4 .5$. s.v.

Ašmi-Šarruma:

An individual named Ašmi-Šarruma is mentioned, in a very fragmentary contest, in KBo 12. 56 obv. 4'; ${ }^{206}$ according to J. Hazenbos, he might be a supervisor, who presumably controlled the movements of goods or offerings, but in reality we cannot infer anything precise from this

${ }^{199}$ See Ünal 1998, 40-43.

${ }^{200}$ See Ünal 1998, 43-44.

${ }^{201}$ See $\mathrm{n}$. 28. The grammatical analysis of this name is not clear; for the ending $-u$ see Wegner 2007, 129, 130, 188. Cfr also the name Madu, see here $\S 4$ 4.4.5. s.v.

${ }^{202}$ See for example Richter 2010, 522 .

${ }^{203}$ See $\S 4.3 .1$.

${ }^{204}$ See Doğan-Alparslan 2007, 250.

${ }^{205}$ See de Martino - Giorgieri 2008, 52-53; see Zehnder 2010, 74, for the ambiguity of the element ali (either Hurrian or Luwian) in personal names.

${ }^{206}$ See Hazenbos 2003, 54-55. 
passage. ${ }^{207}$ The presence of Arma-ziti (obv. 8') could help to date the text to the second half of the thirteen century. As we have already said, a Prince Ašmi-Šarruma is documented in the Early Imperial age.

This name is composed with the Hurrian verb ažm-. ${ }^{208}$

Ehli- ${ }^{D}$ XXX (Ehli-Kušuh):

In the inventory texts KBo 18. 153 (IV 14'), KUB 26. 66 (III 2, 4, 7, IV 14) that regard the movement of metals, Ehli-Kušuh is a supervisor; he had controlled and recorded the people who had previously received and kept metal materials. ${ }^{209}$

J. de Roos $(2007,73)$ restores the fragmentary personal name $E h l i^{-}{ }^{\mathrm{D}}[$ as Ehli- ${ }^{\mathrm{D}}$ XXX in the tablet KUB 15. $5+$ (obv. II 9'). ${ }^{210}$ On this text see $\S$ 4.4.4. s.v. Heba-piya.

In personal names composed with a divine name and with the word $e \dot{g} l i$ this verbal form might be interpreted as an imperative, as G. Wilhelm has proposed: "save!". ${ }^{211}$

\section{Ehli-LUGAL-ma (= Ehli-Šarruma):}

In the inventory text KUB 40.96 III $24{ }^{,},{ }^{212}$ that can be dated to the time of Hattušili III on the basis of the names of other mentioned persons (as for example Prince Hešni ${ }^{213}$ and the Chief Scribe UR.MAH-ziti), EhliŠarruma is charged with the control of goods. Presumably he is the same individual who later becomes king of Išuwa. ${ }^{214}$

\footnotetext{
${ }^{207}$ Hazenbos 2003, 54 with previous literature.

${ }^{208}$ See n. 25.

${ }^{209}$ See Košak 1982, 66-75; Siegelová 1986, 96-108.

${ }^{210}$ Mouton 2007, 252, prefers to avoid any restoration of this name.

${ }^{211}$ Wilhelm 1996, 339-341; Wilhelm 1998a, 123.

${ }^{212}$ See Košak 1982, 81; Siegelová 1986, 281.

${ }^{213}$ See de Martino in print.

${ }^{214}$ See de Martino 2010c.
} 
Evri-Šarruma (EN-LUGAL / EN.LUGAL-ma /Ibri-LUGAL-ma):

An individual by this name ${ }^{215}$ appears in two court proceedings (KUB 13. $35+$ III 7, IV 21; ${ }^{216}$ KUB 26. 49 rev. 9'); he is mentioned, in a fragmentary passage, also in the inventory KUB 42. 51 rev.? 5, together with Nerikkaili; ${ }^{217}$ this can suggest that the text belongs to the time of Hattušili III. This Evri-Šarruma might be the GAL DUMU ${ }^{\text {MEŠ }}$ É.GAL who is the holder of the seal, the impression of which has been found in the archive of Nişantepe no. 134: i(a)pari-SARMA REX.FI[LIUS] MA[GNUS].DOMUS. FILIUS. ${ }^{218}$ M. Marizza (2006, 163-164) believes that he might be also the prince (DUMU.LUGAL) mentioned among the witnesses of treaty concluded by Tuthaliya IV with Kurunta (IV 35) and documented in the impressions of some seals as SBo II $14{ }^{219}$ and Nişantepe nos. $133,135,{ }^{220}$ where he bears the title REX.FILIUS. The strict relationship of Evri-Šarruma with the royal family appears also in the divinatory text KUB $5072+$ IV 1', ${ }^{221}$ where he is mentioned immediately after Nerikkaili. In consideration of all these elements I cannot exclude that he might have been one of Hattušili III's sons. ${ }^{222}$

This name is composed with the well known word evri "lord", that is documented in several Hurrian personal names. ${ }^{223}$

Šaušga-muwa:

In the seal impression SBo II 79 an individual by this name has the title URBS.DOMINUS ${ }^{224}$ that corresponds to Cun. EN URU(-LIM). ${ }^{225}$ A

\footnotetext{
${ }^{215}$ See van den Hout 1995, 136-138.

${ }^{216}$ See Werner 1967, 10-11, 12-13.

${ }^{217}$ See Košak 1982, 183; Siegelová 1986, 344-345.

${ }^{218}$ See Herbordt 2005, 136.

${ }^{219}$ See Güterbock 1942, 66.

${ }^{220}$ See Herbordt 2005, 136.

${ }^{221}$ See Lefèvre-Navaro - Mouton 2008,34, 36, where the personal names in question is read ${ }^{\mathrm{m}}$ TI.LUGAL instead of ${ }^{\mathrm{m}}$ EN.LUGAL.

${ }^{222}$ A different person is Evri-Šarruma mentioned in some texts from Ugarit, see van den Hout 1995, 137-138.

${ }^{223}$ See Wilhelm 1998a, 124; Giorgieri 2000b, 290.

${ }^{224}$ See Hawkins 2005a, 270.

225 See Hawkins 2005a, 271.
} 
scribe who bears this same name is documented by several seal impressions, see $\S 4$ 4.4.5. s.v.

This hybrid name is composed with the Hurrian divine name Šaušga and with the Luwian word muwa- "might" that forms many Anatolian personal names. $^{226}$

Šaušga-piya:

He is mentioned in the court proceeding KUB $31.76+$ KUB 40.88 IV 19 ', ${ }^{227}$ according to this text he was "Overseer of the Seal Cutters".

This is another another hybrid name; it is composed with the Luwian word piya- "gift". 228

Šaušga-Runtiya:

On the seal impression from Nişantepe no. $381^{229}$ Šaušga-Runtiya has the title URBS.DOMINUS HATTI-URBS that, according to D. Hawkins, ${ }^{230}$ might correspond to Cun. EN/BĒL(U) ${ }^{\text {URU }}$ Hatti. $^{231}$ I agree with D. Hawkins ${ }^{232}$ that this Šaušga-Runtiya is not the "Prince of Tarhuntašša" (see § 3), but a different individual. We cannot say if he might be the same person who is mentioned in the court proceeding KUB 31.76 + KUB 40. 88 III 19', ]21', see § 4.4.8. s.v.

\footnotetext{
${ }^{226}$ See Zehnder 2010, 85-87.

${ }^{227}$ See Werner 1967, 24-25.

${ }^{228}$ See Zehnder 2010, 89-90.

${ }^{229}$ See Herbordt 2005, 182; see also Mora, 2010, 220.

${ }^{230}$ Hawkins 2005a, 309-310.

${ }^{231}$ On this title see also Imparati 1974, 58-59.

${ }^{232}$ Hawkins 2005a, 271.
} 
Šindi-Tešob:

An individual by this name, who has the title prince (REX.FILIUS), is the holder of the Nişantepe seal no. $385{ }^{233}$

The first element of this name, that is documented also at Nuzi (ŠindibTešob; Šindab-šeni), ${ }^{234}$ is a verbal form šind $=i=b$; it might be connected to the word šindi "seven" which is productive in Hurrian onomasticon ${ }^{235}$ and it might mean "to multiply by seven (?)".

Tagi-Šarruma:

A cup-bearer by this name is documented by the seal impression Nişantepe no. $391 .^{236}$

This name, composed with the Hurrian verb tag- (see here s.v. TagiTešob), was held by several individuals, documented by Hittite texts and seal impressions (see $\S 4.4 .5$. s.v.)

Tagi-Tešob:

On the seal impression from Nişantepe no. $404^{237}$ there are two names (Tagi-Tešob and Kuruntiya) and only one title, that is prince (REX.FILIUS). D. Hawkins has advanced the hypothesis that the holder of this seal had a double-name. ${ }^{238}$

This name $(t a g=i(=b)-T e s ̌ o b)$ is composed with the verb tag- "to light, to shine", that can be found in several Hurrian personal names; ${ }^{239}$ this

\footnotetext{
${ }^{233}$ See Herbordt 2005, 183; Hawkins 2005a, 271.

${ }^{234}$ See Gelb - Purves - MacRae 1943, 135, 257; Cassin 1977, 129.

${ }^{235}$ See Giorgieri 2000b, 289 and n. 45.

${ }^{236}$ See Herbordt 2005, 184; see also Mora 2010, 223.

${ }^{237}$ See Herbordt 2005, 186.

${ }^{238}$ Hawkins 2005a, 272.

${ }^{239}$ See Giorgieri 2000b, 285; Pruzsinszky 2003, 247 n. 218.
} 
same name is documented in the tablets from Tall al-Hādīi $\overline{1}^{240}$ and from Alalah (in the form Tagiya). ${ }^{241}$

Talmiya:

In KBo $10.10,{ }^{242}$ a text that lists women delivered by local communities (and also by individuals) to temple institutions, Talmiya Golden Page

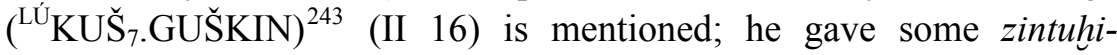
women that belonged to his "house".

This is the hypocoristicon form of the name name Talmi-Tešob.

Talmi-Tešob:

The list of officials KUB 31. 62 I 8' mentions a certain Talmi-Tešob Chamberlain (LÚ ŠÀ.TAM). ${ }^{244}$ According to Th. van den Hout he might be the same individual (GAL-DU), son of Ukkura, ${ }^{245}$ who had been accused of theft, as the court proceeding KUB 13. 35 shows. ${ }^{246}$

This name, that is composed with the Hurrian word tal(a)mi "big, great", ${ }^{247}$ means "Tešob (is) great". ${ }^{248}$

${ }^{240}$ See Pruzsinszky loc. Cit.

${ }^{241}$ See Draffkorn 1959, 53.

${ }^{242}$ See Rutherford 2004.

${ }^{243}$ Or, following Pecchioli Daddi 2003, 88-92, "Scudiero d'oro"; according to this scholar the Golden Pages were officials active not in the army, but in the administration of the state.

${ }^{244}$ See van den Hout $1995,158$.

${ }^{245}$ Van den Hout 1995, 163.

${ }^{246}$ See Werner 1967, 3-20.

${ }^{247}$ See Wegner 2007, 282.

${ }^{248}$ See Wilhelm 1998a, 124. 



\subsubsection{Army}

Early Empire:

Ehli-Tenu:

A Hurrian tablet from the site of Kayalıpinar (Kp 05/226), that might be dated to the Early Empire and refers to a military campaign in the area of Alalah/Mukiš, mentions some individuals who hold Hurrian names. $^{249}$ One of this is Ehli-Tenu (the two others are Ilī-Šarruma and Ehlib-Adda).

This name contains the divine name Tenu (Tešob's vizier) and the imperative of the Hurrian verb e $\dot{g} l-{ }^{250}$

\section{Ehlib-Adda:}

An individual by this name appears in the above mentioned tablet from the site of Kayalıpınar (Kp 05/226) in a very fragmentary contest. We do not know anything about his role and his involvement in a military expedition can be only a conjecture.

This is a Hurro-Semitic hybrid name that can be interpreted as $e \dot{g} l=i=b$ Adda "Addu/a (a West-semitic form of the Weathergod's name) ${ }^{251}$ saved (him)".

\section{Ilī-ŠSarruma:}

He is documented together with Ehli-Tenu in the Hurrian tablet from the site of Kayalıpinar (Kp 05/226), that we have already mentioned.

${ }^{249}$ See Wilhelm 2006, 233-236; Rieken 2009, 130-135.

${ }^{250}$ See Wilhelm 1998a, 123. For other names of this type.

${ }^{251}$ For other names of this type see Richter 2005, 151 n. 16. 
This name too is a hybrid composed with the Akkadian word ilu(m) "god" and the divine name Šarruma: "Šarruma (is my) God".

Imperial Age:

Pendi-Šarruma:

In the seal impression from Nişantepe no. $327^{252}$ an individual named Pendi-Šarruma bears the titles prince and Chief of the Chariot Drivers ${ }^{253}$ $\left(\right.$ MAGNUS.AURIGA $=$ GAL KARTAPPU ${ }^{254}$ ). As we have already said, he might be the same official ${ }^{255}$ who is the sender of the letter RS 94.2523 ${ }^{256}$ (see $\S 4.3 .2$.).

An individual by this same name is the holder of several seals (Nişantepe nos. 322-326) ${ }^{257}$ and has the titles prince, scribe, Chief of the Palace Attendants" (see $\S$ 4.3.2. s.v.). D. Hawkins proposes that these seal impressions belong to the same person, but not to the seal holder of no. 327. On the contrary, I. Singer and M. Marizza do not exclude that all these evidence from Nişantepe and from Ugarit might refer to the same official at different stages of his $\operatorname{career}^{258}$ (see $\S 4.4 .5$ s.v.).

For the first element of this name see $\S 4$ 4.4.5. s.v. Pendi-šena.

$\mathrm{GAL}^{\mathrm{D}} \mathrm{U}(=$ Talmi-Tešob):

A high official by this name, who has the title Chief of the Chariot Drivers (GAL KARTAPPU) is among the witnesses of the treaty of Tuthaliya IV with Kurunta (IV 38). ${ }^{259}$ Following Th. van den Hout we

${ }^{252}$ See Herbordt 2005, 172.

253 So Lackenbacher - Malbran-Labat 2005, 240; Singer 2006b, 244; Marizza 2006, 169; differently Hawkins 2005a, 268

${ }^{254}$ See Hawkins 2005a, 302.

255 See Singer 2006b, 244.

${ }^{256}$ See Lackenbacher - Malbran-Labat 2005, 227-240.

${ }^{257}$ See Herbordt 2005, 171-172.

${ }^{258}$ Singer 2006b; Marizza, 2008, 169.

${ }^{259}$ See Otten 1988, 28-29. 
can suppose that he is the same official who is also witness in KUB 26. 43 rev. $31^{260}$ in a fragmentary line where his title is not preserved. ${ }^{261}$ Talmi-Tešob Chariot Driver of His Majesty is sent to Ugarit to inspect the troops that the king of this country has to provide to the king of Hatti (RS 17.289, 6-7). ${ }^{262}$

${ }^{260}$ See Imparati 1974, 38-39.

${ }^{261}$ Van den Hout 1995, 157, 163-164.

${ }^{262}$ See Singer 1983, 10; van den Hout 1995, 162. 



\subsubsection{Royal Messengers}

Tehi-Tešob:

$\mathrm{He}$, as Hittite messenger, was sent to Syria as the seal impressed on the tablet RS 17.137 shows. ${ }^{263}$ His name appears also on a seal impression from Nişantepe ${ }^{264}$ where he has the title prince (REX.FILIUS). ${ }^{265}$

According to RS 17.137 rev. 4, he is son of a certain Ibizzi, who might be the scribe who signed the tablet KBo 10. 47, see $\S$ 4.4.5. s.v.

An individual named Tihi-Tešob is mentioned also in a letter from Tell Šēh Hamad/Dūr Katlimmu. ${ }^{266}$

This name is composed with the Hurrian verbal root teg- "to grow; to raise", ${ }^{267}$ that is very productive in Hurrian onomasticon of different periods, from the oldest time (see for example Teheš-adal) ${ }^{268}$ to the Late Bronze Age (as for example Tehip-Tilla, ${ }^{269}$ personage who is very often mentioned in the Nuzi texts). Tehi-Tešob $(t e \dot{g}=i=b$-Tešob $)$ means "Tešob has raised (him)". ${ }^{270}$

\section{Teli-Tešob:}

In the letter KBo 28. 47, sent by Ramses to Hattušili III, the Pharaoh mentions a Hittite messenger, whose name is Tili-Tešob (obv. 12'). ${ }^{271}$ His name appears also at the beginning of the Egyptian hieroglyphic copy of the Treaty between Ramses II and Hattušili III in the list of

${ }^{263}$ See Hagenbuchner 1989a, 21; Hoffner 2009, 55; here he is said to be son of Ibizzi (see $\S 4.4 .5$. s.v.), see Klinger 2005, 121.

${ }^{264}$ See Herbordt 2005, 195 no. 453.

265 See Hawkins 2005a, 275.

${ }^{266}$ No. 7, 2", see Cancik-Kirschbaum 1996, 123-128.

${ }^{267}$ See Giorgieri 2000a, 209; Wegner 2007, 285.

${ }^{268}$ See Wilhelm 1998a, 124; Richter 2004, 298.

${ }^{269}$ See Wilhelm1998b, 121 n. 19.

${ }^{270}$ See Giorgieri 2000b, 286.

${ }^{271}$ See Edel 1994, 124-125. 
messengers who brought to Egypt the silver tablet of the Hittite version of the treaty. ${ }^{272}$

This name (tel $=i=b$-Tešob) is composed with the verbal root tel- ${ }^{273}$ that we find also in the name Teli-Šarruma (Emar). ${ }^{274}$

272 See lastly Pernigotti 2010, 97.

${ }^{273}$ See lastly Wegner 2007, 285.

${ }^{274}$ See Pruzsinszky 2003, 230. 
4.4.4. Palace Personnel and People Living at Court

\section{Early Empire:}

fŠaušgatti:

Šaušgatti ${ }^{275}$ is mentioned in the court proceeding KUB 34. $45+\mathrm{KBo}$ 16. 63 obv. $6^{\prime}-10^{, 276}$ (see here also $§$ 4.4.7. s.vv. Agiya and Hudubi); she is accused of having unlawfully taken some Hurrian shirts inlaid with gold, that she affirms were given to her by the king.

Imperial Age:

\section{${ }^{\mathrm{f}}$ Aru-Heba:}

Aru-Heba is mentioned in a scribal training tablet KBo 13.62 (1. 8), that is a copy of a letter sent to the queen. ${ }^{277}$ The original letter tells of a serious illness of the queen, that was reported to the sender of this letter by the queen herself and also through a written message of Aru-Heba. Although we lack precise information for dating this letter, ${ }^{278}$ we may advance the hypothesis that the queen is Pudu-Heba, since she is the Hittite queen more often mentioned in letters; moreover Hurrian names containing the divine name Hebat were trendy at court at the time of Hattušili III and Tuthaliya IV. ${ }^{279}$ She might have belonged to the

275 On this name see lastly Zehnder 2010, 269.

${ }^{276}$ See Werner 1967, 50-51; for the date of this text see van den Hout 1998, 65 and n. 90; Zehnder 2010, 269.

${ }^{277}$ See Hoffner 2009, 335-339; Marizza 2009, 173-175.

${ }^{278}$ See Hoffner 2009, 336.

${ }^{279}$ See also the observations of Marizza 2009, 174. 
personnel of the queen, or she might have been a member of the royal family. ${ }^{280}$

This name can be translated as "Hebat gave her" (ar=u-Hebat); the verb ar- forms many Hurrian personal names. ${ }^{281}$

\section{${ }^{\mathrm{f}} \mathrm{Ašnu}-\mathrm{Heba}$ :}

She is the sender of the post-scriptum written to the queen in the letter KBo 18. 12 (rev. 2); ${ }^{282}$ unfortunately sender and receiver ${ }^{283}$ of the primary letter are not known. We do not know which kind of position this woman had at court; in the address formula she calls herself "your servant" and uses the so called Syrian greeting formula "I have fallen at the feet [of my Lady] three times nine times". This might suggest that the homeland of Ašnu-Heba was, for example, either Kargamiš or Halpa.

This name ${ }^{284}$ is composed with the Hurrian verb of unknown meaning $a z ̌ n-.{ }^{285}$

\section{${ }^{\mathrm{f}}$ Heba-muwa:}

She is mentioned in the report of an oracular inquiry KUB 22.70 rev. $13,14,15,66,67^{286}$ that can be dated to the time of Hattušili III / Tuthaliya $\mathrm{IV}^{287}$ and refers to cases of discord within the royal family. Heba-muwa had been witness of the fact that Pattiya, who presumably

${ }^{280}$ As Marizza 2009, 174, supposes.

${ }^{281}$ See lastly de Martino - Giorgieri 2008, 96-102.

${ }^{282}$ See Marizza 2009, 146-147.

${ }^{283}$ Hagenbuchner 1989b, 87, believes that the receiver was the queen; Marizza, 2009 , 147, proposes that the primary letter might have been written to the king.

${ }^{284}$ On this name see Wilhelm 1998a, 123.

285 See Wilhelm 1998a, 123; de Martino - Giorgieri 2008, 128. See also Zehnder 2010, 130.

${ }^{286}$ See Ünal 1978, 84-85, 98-99.

${ }^{287}$ See lastly Carruba 2000, 75; de Roos, 2007, 66. 
was the mother of one of Tuthaliya IV's wives, ${ }^{288}$ had been object of curses.

This name is a hybrid that contains the Luwian word muwa-, that we have already seen in other personal names. ${ }^{289}$

\section{${ }^{\mathrm{f}}$ Heba-SUM (= Hueba-piya):}

This woman is mentioned several times in the votive text, that can be dated to the time of either Muwattalli II or Muršili III, KUB $155+$ KUB 48. 122 + KUB 43. $66 .{ }^{290}$ This text reports many dreams, that are interpreted by Heba-piya. She might have been a very talented interpreter of dreams and counselor of the king. ${ }^{291}$ She might be the same person who is documented by two seals from Tarsus; in one of them she has the title "princess". ${ }^{292}$

As Heba-muwa, also Heba-piya is a hybrid composed with the divine name Hebat and the Luwian word piya- "gift". 293

Šaušga-ziti:

An individual by this name is mentioned in three court proceedings (KUB 13. $35+$ III $20 ;{ }^{294}$ KUB 40.80 obv. 3, 5, 7, 27; KUB 40.90 obv. $6,8,14{ }^{295}$ ) and in KUB 54. $1 ;^{296}$ we do not know which was his

${ }^{288}$ See Hagenbuchner-Dresel 2010, 158 n. 29.

${ }^{289}$ See Zehnder 2010, 156.

${ }^{290}$ On this text see de Roos 2007, 71-88; Mouton 2007, 244-255; see also de Roos 1998, 160-161.

${ }^{291}$ See de Roos 2007, 58.

292 See de Roos 2007, 59.

${ }^{293}$ See Zehnder 2010, 156

${ }^{294}$ See Werner 1967, 10-11.

${ }^{295}$ See Werner 1967, 67-68.

${ }^{296}$ See Archi- Klengel 1985. 
position at court, but he seems to be very close to the royal family and the queen. ${ }^{297}$

This is a Hurro-Luwian hybrid composed with the Hurrian divine name Šaušga and the Luwian word zida/i- "man".

${ }^{297}$ See van den Hout 1995, 183; de Martino 2010c. 


\subsubsection{Scribes and Chiefs of the Scribes}

Early Empire:

AMAR-ti (= Hubidi):

As we have already said, this scribe is documented in the colophon of the Hurrian tablet KUB 32. $19+(\mathrm{ChS} \mathrm{I} / 141)^{298}$ IV 49-50, ${ }^{299}$ Prayer of Tadu-Heba to Tešob for the Well-being of Tuthaliya III/Tašmi-Šarri, ${ }^{300}$ and in the colophon of the MH purification ritual KBo 22. $129(+)$ 129a. ${ }^{301}$ An individual named Hubidi is mentioned also in the documents from Šapinuwa, see here $\S$ 4.4.1. s.v.

Madu:

The individual who bears this name is documented by the impressions of some seals, ${ }^{302}$ where he has the title Chief Scribe. According to A. Dinçol and B. Dinçol 2008, 14, Madu's seals might be dated to the beginning of the fourteenth century.

A. Dinçol $(1993,129)$ interprets this name as Anatolian and writes that it might be compared to names as Madduwatta and Maddunani. Since this same personal name Madu is attested also at Nuzi, ${ }^{303}$ in my opinion, it might be Hurrian; it could be connected to the root mat-, that we find in names such as Madi (see $\S$ 4.4.6.2. s.v.), Madi-Šarruma etc.

\footnotetext{
${ }^{298}$ See also Singer 2002b, 43-44.

${ }^{299}$ The tablet is MH, see Košak-web site.

${ }^{300}$ See de Martino 2005, 295.

${ }^{301}$ See Groddek 2008, 120-121.

${ }^{302}$ See Dinçol - Dinçol 2008, 26-27, nos. 52-56.

${ }^{303}$ See Gelb - Purves - MacRae 1943, 97.
} 
Early Empire or Late Imperial Age(?):

Pendi[-:

A silver bowl in the Ankara Museum preserves two Hieroglyphic Luwian inscriptions; ${ }^{304}$ in the inscription no. 2 there is the name, unfortunately fragmentary, of the scribe who wrote both inscriptions, that is Pi?-ti?[- = Pendi-[. ${ }^{305}$ As well known the date of the Ankara silver bowl is still controversial; it might be of the time either of Tuthaliya I/II, or Tuthaliya IV, ${ }^{306}$ but even a later date has been proposed. ${ }^{307}$ See here other Hurrian names as Pendi-Šarruma and Pendišena $(\S 4.4 .5$.).

Imperial Age:

Agi-Tešob 1:

In the colophon of the prayer of Muwattalli $\mathrm{II}^{308}$ to the Storm-god concerning the Cult of Kummanni, ${ }^{309}$ the name of the scribe is mentioned, that is, Lurma-ziti, son of Agi-Tešob (KBo 11. 1. Rev. 27'). It is possible that also Agi-Tešob was a scribe too, as van den Hout $(1995,243)$ proposes. According to Gordin $(2010,160)$ he might have

${ }^{304}$ See Hawkins 2005a.

305 See Hawkins 2005b, 194, 197; Gordin 2010, 160; Durnford 2010, 56. For the Hurrian verb pend- see $\S 4$ 4.4.5. s.v. Pende-šena.

${ }^{306}$ See Hawkins 2005b, 200.

${ }^{307}$ See Simon 2009; Durnford 2010.

${ }^{308}$ For the problem of the date of the tablet KBo 11. 1 see van den Hout 1995, 243.

${ }^{309}$ See Singer 2002b, 81-85. 
had a competence in Hieroglyphic Luwian since his name appears on the inscription (of Talmi-Šarruma) ALEPPO $1 .{ }^{310}$

This name can be interpreted as "Let Tešob raise up". ${ }^{311}$

Agi-Tešob 2 (?):

Th. van den Hout $(1999,242-243)$ proposes that the name Aki[-, readable at the end of the list of witnesses in KUB 26. 50 rev. $28^{3}, 312$ (text dated to Tuthaliya IV), might be integrated as Agi-[Tešob]. According to this scholar, the individual who holds this name might be a scribe, because of his position at the end of the list of witnesses.

Alihhini:

$\mathrm{He}$ is the scribe of the copy of the royal edict, originally issued by Tuthaliya I/II, ${ }^{313}$ KUB 13. $9+$. The colophon of this tablet preserves also the genealogy of Alihhini, who was son of Zuwa and grandson of NU.GIŠ.SAR; therefore he lived in the last years of the Hittite Empire. $^{314}$

The etymology of this name is not clear; it might come from a root al$/ a l i-{ }^{315}+$ the suffixes $-\dot{g} e /-h h e$ and $-n i$.

Hešni:

The name of the scribe Hešni son of Naniya ${ }^{316}$ (on Naniya see $\S 4.4 .6$. s.v.) is documented in KUB 25. 10 IV 6' and KUB 44. 24 VI 12'; in my opinion he might be the same individual who is mentioned as priest in

${ }^{310}$ See also Mascheroni 1984, 153.

${ }^{311}$ For names with an imperative verbal form see Wilhelm 1996, 339-341.

312 See Imparati 1974, 38-39.

${ }^{313}$ As the mention of the military campaign in the region of Aššuwa shows, see de Martino - Imparati 1998, 395; differently see lastly Gordin 2010, 165.

${ }^{314}$ See Gordin 2010, 165.

${ }^{315}$ For the verb ali- see de Martino - Giorgieri 2008, 61-62.

${ }^{316}$ See Mascheroni 1984: 155-156. 
the court proceeding KUB 38. 37 III? 5', where he is called to give witness on the case of cult objects, that had been found in the houses of some priests. ${ }^{317}$

Ibizzi:

He is the scribe of the tablet KBo 10. 47, Hittite version of Gilgameš, that, according to J. Klinger $(2005,122)$ comes from the Hurrian text. Ibizzi might be the father of the ambassador Tehi-Tešob. ${ }^{318}$

The etymology of this name is obscure; I have included it in the present catalogue, because its aspect is Hurrian and it was held by a scribe expert in the Hurrian tradition. The second element $-i=z z i(=-i=\check{s} \check{s} e \text { ? })^{319}$ appears in several Hurrian names. ${ }^{320}$ Concerning the first element, I can quote only the word ippi/ibbi "crown", that is documented in the trilingual dictionary from Ugarit (IV 21') recently studied by B. AndréSalvini and M. Salvini. ${ }^{321}$

\section{Kuzi-Tešob:}

His name appears in the colophons of the omina of Syrian tradition ${ }^{322}$ KBo 10. 7 IV 14 ([ $\left.{ }^{\mathrm{m}} K\right] u$-zi-it-te-eš-šu-u-pa) and KUB 8. 29 IV $1\left(\left[{ }^{\mathrm{m}} K\right] u\right.$ $\left.z i-{ }^{\mathrm{D}} \mathrm{U}-u p\right)$. According to A. Kammenhuber, these two omina are direct imports from Syria. ${ }^{323}$

This name, borne also by a king of Kargamiš, is composed with the verb $k u z-{ }^{324}$ that forms also other Hurrian names. ${ }^{325}$

\footnotetext{
${ }^{317}$ See de Martino, in print. For this name see $\S$ 4.4.1. s.v. Ali-ḩešni.

${ }^{318}$ See $\S$ 4.4.3. s.v.

${ }^{319}$ On tis suffix see Giorgieri 2000a, 204.

${ }^{320}$ See Gelb - Purves - MacRae 1943, 279; see also Agizzi (king of Qatna).

${ }^{321}$ André-Salvini - Salvini 1998, 7, 13.

${ }^{322}$ See Mascheroni 1984, 159.

${ }^{323}$ Kammenhuber 1976, 83-84.

${ }^{324}$ See Wegner 2008, 265: "zurückhalten".

${ }^{325}$ See for example Pruzsinszky 2003, 244 n. 191.
} 
Pendi-Šarruma:

An individual by this name is the holder of several seals, whose impressions are preserved in the archives of Nişantepe (nos. 322$326) ;{ }^{326}$ he has the following titles: Chief Scribe MAGNUS.SCRIBA (no. 322), prince and Chief Scribe REX.FILIUS MAGNUS.SCRIBA (no. 323); prince, Chief Scribe, Chief of the Palace Attendants REX.FILIUS MAGNUS.SCRIBA MAGNUS.DOMUS.FILIUS (nos. 324-326).

As we have already said, he might be the same official who in the seal impression from Nişantepe no. $327^{327}$ has the titles prince and Chief of the Chariot Drivers ${ }^{328}$ (MAGNUS.AURIGA $=$ GAL KARTAPPU $^{329}$ ), see $\S$ 4.4.2 s.v. Pendi-Šarruma.

For the first element of this name see here s.v. Pendi-šena.

Pendi-šena:

A scribal graffito from Boğazköy preserves the name, written in Hieroglyphic Luwian, Patisina, that might correspond to the Hurrian name Pendi-šena. ${ }^{330} \mathrm{Sh}$. Gordin proposes that this Pendi-šena might have been a scribe on wood active in the "House of Craftsmen" in the Hittite Capital. ${ }^{331}$

${ }^{326}$ See Herbordt 2005, 171-172.

${ }^{327}$ See Herbordt 2005, 172.

328 So Lackenbacher - Malbran-Labat 2005, 240; Singer 2006b, 244; Marizza 2006, 169; differently Hawkins 2005a, 268.

${ }^{329}$ See Hawkins 2005a, 302.

${ }^{330}$ See Hawkins 2005a, 268; Gordin 2010, 163 and n. 27.

${ }^{331}$ Gordin 2010, 163; on the scribes on wood see now van den Hout 2010. 
This name is composed with the Hurrian verb $f / p a / e n d$ - and the word šen (a) and its meaning is: "the/his brother made (him) in the right way / allowed (him) to be right". 332

Šaušga-muwa:

A scribe who bears this name is documented by several seal impressions found at Nişantepe (nos. 366-372). ${ }^{333}$ In the seal impressions nos. 368371 Šaušga-muwa has the title SCRIBA; in the seal impressions nos. 366-367 he has the titles prince and scribe (REX.FILIUS, SCRIBA). As S. Herbordt writes, we can presume that he is not the well known prince of Amurru, but a different individual, ${ }^{334}$ who might perhaps be the same official who is the holder of the seal SBo II $79,{ }^{335}$ see 4.4.1. s.v.

Šaušga-Runtiya:

This individual is documented by the seal impression from Nişantepe no. $380 ;{ }^{336}$ he has the title SCRIBA.

$\breve{S} a<$ uš $>$ ga-walwi (?):

The seal impression Nişantepe no. $382^{337}$ preserves the personal name $s \grave{a}-k a-\mathrm{LEO}_{2}$ that $\mathrm{D}$. Hawkins proposes to read Šaušga-walwi. ${ }^{338} \mathrm{It}$ combines the divine name Šaušga and the Luw. word walwa/i"lion"; 339 a Hurrian reading of this name as Šaušga-eari ${ }^{340}$ cannot be excluded. The holder of this seals bears the title "scribe".

\footnotetext{
332 See Giorgieri 2000b, 286.

${ }^{333}$ See Herbordt 2005, 178-180; see also Mora 2010.

${ }^{334}$ See Herbordt 2005, 82; see also Hawkins 2005a, 270

335 See Hawkins 2005a, 270.

${ }^{336}$ See Herbordt 2005, 182.

${ }^{337}$ See Herbordt 2005, 182; see also Mora 2010, 224.

${ }^{338}$ Hawkins 2005a, 271.

${ }^{339}$ See Hawkins 2005a, 293-294.

${ }^{340}$ For the Hurrian word for "lion", eari, see Röseler 1999, 396-400.
} 


\section{Tadikkanna:}

A scribe by this name has written the tablet KUB 19.31 + ("Muršili II's Dictate to Tuppi-Tešob's Syrian Antagonists"); ${ }^{341}$ his name appears in the colophon of the tablet (IV 14'). ${ }^{342}$

This name might be Hurrian ${ }^{343}$ and it might contain the well known Hurrian verbal root tad-. Concerning the second part of the name, we might recognize the suffixes $=k k V$-and $=o=n n i,{ }^{344}$ but in this case we should find a form ${ }^{*}$ Tadikkunni (or we should suppose a change $o>a$, tad $=i=k k=a(<o)=n n i)$; the meaning of this name might be "the one who loves; who is full with love". Otherwise we might analyse this name as tad $=i=k(<b)$-Kanna, but this latter element Kanna is unfortunately unknown; ${ }^{345}$ we know only the word kani that appears in names as Ariškani. $^{346}$

Tagi-Šarruma:

Tagi-Šarruma prince (DUMU.LUGAL) is among the witnesses of the treaty concluded by Tuthaliya IV with Kurunta (IV 35). ${ }^{347}$ A prince (REX.FILIUS) by this name is documented by several seal impressions from Nişantepe (nos. 394-403); ${ }^{348}$ in these impressions he has also the title Chief Scribe (MAGNUS.SCRIBA). In the seal impression from Nişantepe no. $393^{349}$ Tagi-Šarruma has only the title prince, whereas in the impression no. $392^{350}$ he bears only the title Chief Scribe. I. Singer has convincingly shown that Prince Tagi-Šarruma Chief Scribe might be the same Hittite high official who is Governor of the Land in a letter from Tell Šēh Hamad/Dūr Katlimmu and who is the owner of the seal impressed on the tablet RS 17.403. According to I. Singer this same

\footnotetext{
${ }^{341}$ See Miller 2007.

${ }^{342}$ See Miller 2007, 128. See also KBo 11. 16 + KUB 10. 21 VI 1'.

${ }^{343}$ See Yakubovich 2010, 372.

${ }^{344}$ See Wegner 2007, 55-56; Giorgieri 2000, 211-212.

${ }^{345}$ I thank M. Giorgieri for this suggestion.

${ }^{346}$ See Richter 2010, 506.

${ }^{347}$ See Otten 1988, 26-27; on this official see van den Hout 1995, 132-136.

${ }^{348}$ See Herbordt 2005, 184-186.

${ }^{349}$ See Herbordt 2005, 184.

${ }^{350}$ See Herbordt 2005, 184.
} 
Tagi-Šarruma might be the official who validated with his seal the document from Ugarit RS 17.251; he might be also the supervisor mentioned in the inventory text KBo 31. 50 III 1, ${ }^{351}$ As I. Singer observes, Tagi-Šarruma should have been very young when the treaty with Kurunta was concluded. ${ }^{352}$ C. Mora, differently from I. Singer, believes that Tagi-Šarruma was not a Hittite official, but a dignitary of Kargamiš. ${ }^{353}$ It remains uncertain whether Tagi-Šarruma mentioned in KUB 40. 95 II $4{ }^{354}$ (see also KBo 31.69 r.c. $10^{, 355}$ ) is the prince and Chief Scribe or another individual.

For the verb tag- see $\S 4$ 4.4.1. s.v. Tagi-Tešob.

Talmi-Tešob:

As we have already said (see §4.3.1.), a scribe by this name, son of Walwa-ziti/UR.MAH-ziti and grandson of Mittanna-muwa, is documented by some texts ${ }^{356}$ and also by the impressions of seals from the Hittite capital. ${ }^{357}$

He is the scribe who has written the $13^{\text {th }}$ tablet of the hišuwa-festival. ${ }^{358}$

Tehup-ŠEŠ (= Tehup-šeni):

He is the scribe of the tablet KUB 55. 59 (ChSI/3-2 22).

This name can be interpreted as $t e \dot{g}=u=m>p^{359}$-šen (a); the Hurrian verb te $\dot{g}$ - "grossziehen" ${ }^{360}$ forms other personal names. ${ }^{361}$

\footnotetext{
${ }^{351}$ Singer 2003.

${ }^{352}$ See Singer 2003, 344 and n. 24.

${ }^{353}$ Mora 2004, 437-438.

${ }^{354}$ See Siegelová 1986, 268-269.

355 See Siegolová 1986, 272-273.

${ }^{356}$ See van den Hout 1995, 158, with previous literature

${ }^{357}$ See Herbordt 2005, 223-224 nos. 625-630; Dinçol - Dinçol 2008, 32 no. 98.

${ }^{358}$ See lastly Doğan-Alparslan 2007, 253-254.

${ }^{359}$ For $m+\check{s}>p \check{s}$ see Giorgieri 2000b, 287.

${ }^{360}$ See lastly Wgner 2007, 285.
} 


\section{Teli-Šarruma:}

An official by this name is documented by the seal impressions from Nişantepe nos. 456-459 where he bears the title prince (REX.FILIUS); this same name is documented also on SBo II nos. 15 (REX.FILIUS) and 224 (SCRIBA). ${ }^{362}$ According to C. Mora $(2004,438 ; 2008,560)$ he might be the same individual whose name appears in documents from Ugarit and who could be the son of the king of Kargamiš (either of Šahurunuwa or of Ini-Tešob).

As we have already said, this name, that is documented also at Emar, ${ }^{363}$ contains the verb tel- "to fight". ${ }^{364}$

Ulmi-Šarruma:

The fragmentary colophon of an unpublished text (Bo 6780 Vo 3') 365 $^{365}$ mentions this individual; his title is not preserved, but we can suppose that he was scribe. In this colophon he appears together with Pihawalwi, who is known as scribe-on-wood. ${ }^{366}$ An individual who bears the name Ulmi-Šarruma is mentioned in the letter KUB 40.1 rev. 7, ${ }^{367}$ but, since the passage is very fragmentary, we cannot say if he is the same personage or another homonymous official.

This name is composed with the Hurrian word ulme- "weapon" 368 and it can be compared to Ulmi-Tešob.

${ }^{361}$ See Gelb - Purves -MacRae 1943, 264; Wilhelm 1998a, 123; Pruzsinszky 2003, 248

${ }^{362}$ See Herbordt 2005, 195, 275.

363 See Pruzsinszky 2003, 230.

${ }^{364}$ See Wegner 2007, 285.

${ }^{365}$ See Mascheroni 1984, 164; Fuscagni 2007, 151.

${ }^{366}$ See Gordin 2010, 162 and n. 24.

${ }^{367}$ See now Marizza 2009, 150 n. 6.

${ }^{368}$ See Salvini 1991, 180. 



\subsubsection{Cult Personnel:}

Imperial Age:

Agiya:

In the oracular text KUB 5. $6+$ II $11,{ }^{369}$ that has been dated to the time of Hattušili III, ${ }^{370}$ the case is examined of the offer made by Agya. S. Herbordt $(2005,78)$ proposes the Agiya of KUB 5. 6 is the same individual who is the owner of seal Nişantepe no. 2; here he bears the title "priest".

Hešni:

On Hुešni “priest” see §4.4.5. s.v. Hูešni.

\section{f Manniya:}

In HT 2, a list of female singers, Manniya, singer from Ankuwa, is mentioned (IV 12). ${ }^{371}$ This same name is documented on a seal impression from Nişantepe (no. 231); ${ }^{372}$ the seal holder Manniya has here only the title FEMINA.

${ }^{369}$ See Prechel 1996, 103; Miller 2006, 239-240.

${ }^{370}$ See van den Hout 1995, 242; Miller 2006, 239; Haas 2008, 68 and n. 257; Singer 2008, 32.

${ }^{371}$ See lastly Rutherford 2004, 389.

${ }^{372}$ See Herbordt 2005, 155. 
Since Manniya is documented also at Nuzi as a masculine ${ }^{373}$ and a feminine name, ${ }^{374}$ we include it among the Hurrian names, even if a Luwian etymology cannot be excluded, as Th. Zehnder observes. ${ }^{375}$

Naniya:

The impressions of two seals from the archive of Nişantepe (nos. 278 and 279$)^{376}$ mention an individual named Naniya. In one of them (no. 279) he is said to be patili priest.

He might be the same individual who is known (KUB 25. 10 IV 6 $6^{\prime 377}$ KUB 44. 24 VI 12, ${ }^{378}$ ) as father of the scribe Hešni. ${ }^{379}$ In the court proceeding KUB 13. $34+40.84$ IV $29^{380}$ a person named Nanniya ( ${ }^{\mathrm{m}} \mathrm{Na}$-an-ni-ya-aš) is mentioned; we do not know if also this document refers to the priest Naniya.

As we have already said, this name is documented also at $\mathrm{Nuzi}^{381}$ and Alalah; ${ }^{382}$ therefore I believe that it is Hurrian and it is not etymologically connected to the Luwian word nani-, from which other names, as for example Nani ${ }^{383}$ and Naninzi, come. ${ }^{384}$ This hypocosticon name contains the Hurrian verbal root nan- the meaning of which might be "to smash; to defeat"; ${ }^{385}$ this same root is present also in personal names documented in the Kültepe tablets, as Nanib-Adal and Nanib-

\footnotetext{
${ }^{373}$ See Gelb - Purves - MacRae 1943, 95.

${ }^{374}$ See Cassin 1977, 91.

${ }^{375}$ Zehnder 2010, 214.

${ }^{376}$ See Herbordt 2005, 163.

${ }^{377}$ See Nakamura 2002, 140-141.

${ }^{378}$ See McMahon 191, 234.

${ }^{379}$ See de Martino in print.

${ }^{380}$ See Werner 1967, 40-41.

${ }^{381}$ See Gelb - Purves - MacRae 1943, 103.

${ }^{382}$ See von Dassow 2008, 293.

383 On this name see Zehnder 2010, 55.

${ }^{384}$ So also Zehnder 2010, 78; differently see Hawkins 2005a, 266.

${ }^{385}$ See Neu 1996, 412;Wegner 2007, 268.
} 
Šarri, ${ }^{386}$ and in the Nuzi texts, as for example Nanib-Tešob, Nanib-Tilla etc. $^{387}$

\section{Pendib-Šarri:}

The "Apology" of Hattušili III (III 1) ${ }^{388}$ mentions Puduheba's father, whose name was Pendib-šarri and who was priest ( $\left.{ }^{\mathrm{L}} \mathrm{SANGA}\right)$; in KBo 6. 29 I 17-18 it is added that he was priest of Ištar.

This name means "the deified king made (him) right", since it is composed with the verb f/palend- "to be right; to bring to the right condition". ${ }^{389}$ This same name is documented also at Nuzi (as PandibŠarri) ${ }^{390}$ and at Emar. ${ }^{391}$ The Hurrian verb f/pa/end- is very productive in the onomasticon of several regions: in the Nuzi tablets we find several names composed with this same verb as, for example, PandibŠarri, Pandib-Tilla, Pandib-Tešob, Pandib(>šs $)^{392}-$ šenni; ${ }^{393}$ the same can be said for Alalah texts. ${ }^{394}$ Moreover, as well known, one of the kings of Amurru had the name Bentešina/Pendi-šena. ${ }^{395}$ See here also the names Pandiya, Pendi-Šarruma, Pende-šena.

In my opinion, all these name can be connected to the verb $f / p a / e n d-$, since its positive meaning very well responds to the celebrative character of many Hurrian names, but we cannot exclude that some of them are composed with the verb pend- "to let go back", ${ }^{396}$ as R. Pruzsinszky proposes for example for the name Pendib-Šarri. ${ }^{397}$

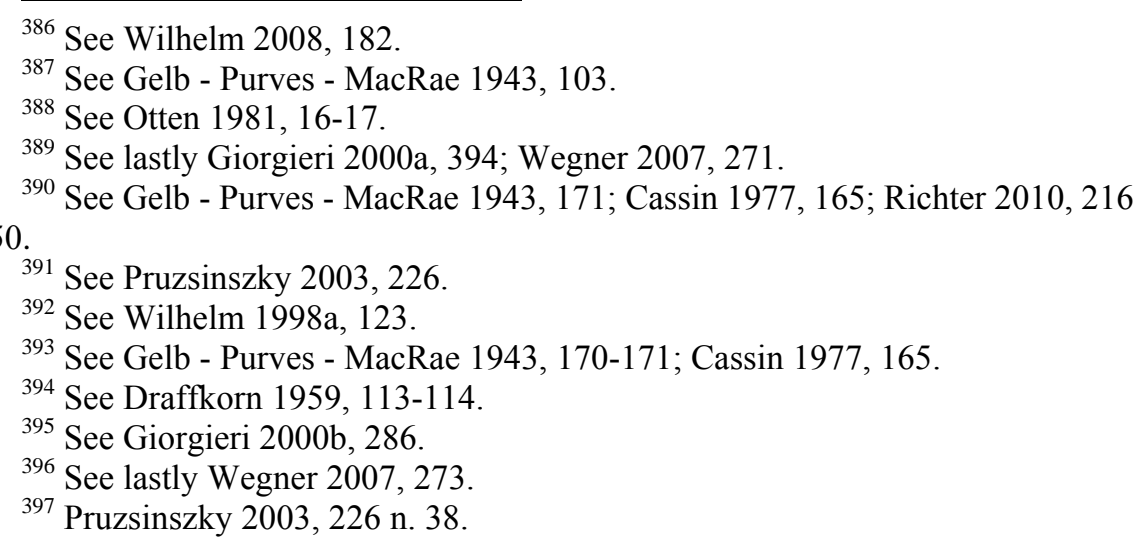


It is interesting to note that in Puduheba's father name, belonging to an individual who was born and lived in Kizzuwatna, the person suffix $-b$ ( $f e n d=i=b$ ) has not fallen in front of the second element šarri as on the contrary it usually happens in Hurrian names mostly of the Hittite area. ${ }^{398}$ We cannot say if this was a constant trait in Kizzuwatnean Hurrian names of this kind, but we can compare also the name EhlibAdda borne by an individual who might have been from Kizzuwatna (see $\S$ 4.4.2.).

4.4.6.2. "Authors" or Experts of Rituals:

Early Empire:

${ }^{\mathrm{f}}$ Allai-turahhi:

${ }^{\mathrm{f}}$ Allai-turahhi from Mukiš (MUNUS ${ }^{\mathrm{URU}}$ Mukiš) ${ }^{399}$ is the "author" of rituals of Hurrian tradition, ${ }^{400}$ that might have been known in Hattuša in the Early Empire, at the time of Tuthaliya I/II and Arnuwanda I. ${ }^{401}$

This name is documented in other regions of the Ancient Near East (Mari, Nuzi, Alalah) $)^{402}$ and it is composed with the words alla $=i$ "woman" $" 403$ and $\operatorname{tur}(i)=o=$ hhe "masculine". ${ }^{404}$

Ašnu-Nikkal:

${ }^{m} A \check{s}$-nu-ni-gal-li is he author of the ritual of Kizzuwatnean tradition KUB 9. $2^{405}$ together with his colleagues Taguya and Madi; they are

${ }^{398}$ See Wilhelm 1998a, 123; Giorgieri 2000b, 286.

${ }^{399}$ So in the colophons of the tablets of these rituals, see Haas - Wegner 1988, $51,68,70,91,105,143$.

${ }^{400}$ See Haas - Wegner 1988, 48-207.

${ }^{401}$ See Miller 2004, 506-511.

${ }^{402}$ See Haas - Wegner 1988, 4; Zehnder 2010, 106.

${ }^{403}$ See lastly de Martino - Giorgieri 2008, 66.

${ }^{404}$ See lastly Wegner 2007, 288. 
said to be AZU-priests. This text, even if the tablet KUB 9. 2 was written in the late 13 th century, ${ }^{406}$ might go back to an earlier time. ${ }^{407}$

This name is composed with the divine name Nikkal and with the Hurrian verb ažn-, of unknown meaning, that is present in very few other names. ${ }^{408}$

${ }^{\mathrm{f}} \mathrm{Ašdu}:$

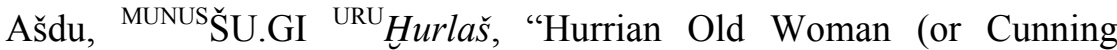
Woman $\left.^{409}\right) ",{ }^{410}$ is the "author" of a ritual (CTH 490) $)^{411}$ that goes back to the Early Empire. ${ }^{412}$

This name, that comes from the Hurrian word ašt "woman", can be found also at Mari and Nuzi. ${ }^{413}$

Kiziya:

Kiziya from Alalah (LÚ URU Alalah) is the "author" of the so-called allunuwašši(yaš) ritual, ${ }^{414}$ that goes back to the Early Empire. ${ }^{415}$

This name might be connected to a root of unknown meaning ke/iz(z)that is documented in several other personal names from different archives, as Mari (Kizziya $\left.{ }^{416}\right)$, Tell al-Rimah/Karana $\left(\mathrm{Kizzi}^{417}\right)$, Nuzi

405 See Strauss 2006, 274-275.

${ }^{406}$ See Košak-web site.

${ }^{407}$ See Klinger 1996, 26; Strauss 2006, 255, referring to another ritual where Madi appears.

${ }^{408}$ See de Martino - Giorgieri 2008, 128; Zehnder 2010, 130.

${ }^{409}$ See Yakubovich 2010, 18.

${ }^{410}$ On the possible meanings of this expression see Görke 2010, 273-275.

${ }^{411}$ See Görke 2007; Görke 2010.

${ }^{412}$ See Görke 2007, 345; 2010, 29.

${ }^{413}$ See de Martino - Giorgieri 2007, 129.

${ }^{414}$ See Salvini - Wegner 1986, 261-279; see also Bawanypeck - Görke 2007, $59-68$

${ }^{415}$ See lastly Miller 2004, 506; Bawanypeck - Görke 2007, 59-68, 59.

${ }^{416}$ See Sasson 1974, 363.

${ }^{417}$ See Sasson 1979, 44. 
(Kiz-adal, Kizzi-harbe/a; ${ }^{418}$ Kizzi, Kizziya ${ }^{419}$ ), Alalah $\left(\operatorname{Kizza}^{420}\right)$, Emar (Kizzi). ${ }^{421}$

Madi:

Madi, Ammihatna and Tulbi(ya), purapši priests from Kummani, are the "authors" of the ritual KBo 23. $1+;^{422}$ together with Taguya and AšnuNikkal, AZU-priests ${ }^{423}$ Madi is "author" also of the ritual KUB 9. 2, that we have already mentioned. ${ }^{424}$ Moreover this name appears in some catalogue entries: KBo 31. 8 + IV $26^{425}$ (together with Ammihatna, Tulbi(ya), purapši- priests from Kizzuwatna); KBo $31.4+\mathrm{V} 22^{, 426}$ (together with Tulbiya, Naniyanni, Ammiyatala, Pabanikki =Paba-nigri,

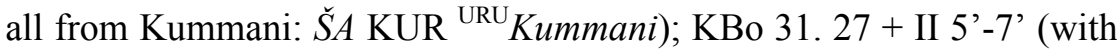
Tulbi(ya) and Ammihatna); ${ }^{427}$ KUB 30. 51+ II 3'-6, ${ }^{428}$ (with Tulbi(ya) and with Ammihatna); KUB 30. 63 V 2'-7 ${ }^{429}$ (with Tulbi(ya) ).

The Hurrian word madi means "wisdom"; ${ }^{430}$ this same name is documented also at Alalah ${ }^{431}$ and Emar. ${ }^{432}$

Naniyanni

As we have already said, he is mentioned in the catalogue entry KBo $31.4+\mathrm{v}$ 22' (together with Tulbi(ya), Madi, Ammiyatala, Pabanikki/Paba-nigri, all from Kummani). ${ }^{433}$

\footnotetext{
${ }^{418}$ See Gelb - Purves - MacRae 1943, 89.

${ }^{419}$ See Cassin 1977, 85.

${ }^{420}$ See von Dassow 2008, 249 n. 21.

${ }^{421}$ Pruzsinszky 2003, 243-244 n. 185.

${ }^{422}$ See Strauss 2006, 253-271.

${ }^{423}$ On the personal name Ammihatna, see n. 136.

${ }^{424}$ See Strauss 2006, 274-276.

${ }^{425}$ See Dardano 2006, 28-29.

${ }^{426}$ See Dardano 2006, 104-105.

${ }^{427}$ See Dardano 2006, 152-153.

${ }^{428}$ See Dardano 2006, 128-129.

${ }^{429}$ See Dardano 2006, 246-247.

${ }^{430}$ See Giorgieri 2005a, 211; Wegner 2007, 266.

${ }^{431}$ See Draffkorn 1959, 43.

${ }^{432}$ See Pruzsinszky 2003, 244.
} 
The name Naniyanni can be connected to the verbal root nan- "to smash; to defeat" ${ }^{434}$ plus the suffix $-a=n n i .{ }^{435}$

\section{Paba-nigri:}

He is the "author" of the ritual KBo $5.1 ;{ }^{436}$ he is said to be a patili-priest from Kummani (obv. I 1); this text, although it survives in a tablet of the Imperial Age, ${ }^{437}$ goes back to the $14^{\text {th }}$ century. ${ }^{438}$ His name can be restored in the catalogue entry KUB 8.71 obv. $1,{ }^{139}$ this entry presumably refers to the ritual KBo $5.1 .^{440}$ As we have already written, the "author" of ritual Pabannikki, mentioned in the catalogue entry KUB 31.4 + V 22' (together with Tulbi(ya), Naniyanni, Ammiyatala, all from Kummani) ${ }^{441}$ can be identified with Paba-nigri. ${ }^{442}$

Paba-nigri quoted in KBo 31. 6 III 3', a catalogue of Kizzuwatna and Arzawa rituals, might be the same priest known from the documents that we have just mentioned, as J. Miller has proposed. ${ }^{443}$

This name is composed with the words $f / p a b a$ "mountain" 444 and negri "bolt"; 445 M. Salvini ${ }^{446}$ interprets this name as "Catenaccio della montagna"; in my opinion, it might be a nominal sentence, ${ }^{447}$ "the mountain (is) the bolt", meaning that the mountains (or a particular mountain) are the border of one region and give access to another land.

\footnotetext{
${ }^{433}$ See Dardano 2006, 104-105.

${ }^{434}$ See Neu 1996, 412; Wegner 2007, 268.

435 See Giorgieri 2000a, 211.

${ }^{436}$ See Strauss 2006, 284-309; see also Haas 1998, 69-71.

${ }^{437}$ See Strauss 2006, 284.

${ }^{438}$ See Haas 1998, 69 and n. 108.

${ }^{439}$ See Miller 2004, 381-383; Dardano 2006, 66-67.

${ }^{440}$ See Miller 2004, 381 n. 585.

${ }^{441}$ See Dardano 2006, 104-105.

${ }^{442}$ See Strauss 2006, 281 n. 190 with previous literature.

${ }^{443}$ Miller 2004, 32-33 and n. 53.

${ }^{444}$ See Giorgieri 2005a, 199.

${ }^{445}$ See Wegner 2007, 269.

${ }^{446}$ Salvini 1991, 178.

${ }^{447}$ For other Hurrian names of this type see Wilhelm 1998a, 124.
} 
fŠalašu:

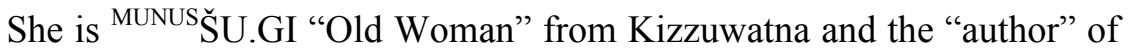
purification rituals of Hurrian tradition. ${ }^{448}$

Šalašu is a name that comes from the Hurrian word šala "daughter"; 449 as V. Haas has written, ${ }^{450}$ the suffix $-\check{s} u$, that is attached to $\check{s} a l a$, can be recognized in several feminine personal names.

f̌́ilalluhi:

The "Old Woman" ( ${ }^{\mathrm{MUNUSS}}$ ŠU.GI) Šilalluhi performs ${ }^{\mathrm{f}}$ Kuwattalla's ritual $^{451}$ KUB 35. $40+$ IV 7'; ${ }^{452}$ KUB 35. 41 IV 3' (without the appellative "Old Woman"453); KUB 35. 33 IV 1'-2'; ${ }^{2}{ }^{4}$ KUB 35.18 I $2 .{ }^{455}$ The earliest version of these rituals goes back to the Early Empire; moreover Kuwattalla is presumably the same person who was granted some land by Arnuwanda I and Ašmunikkal. ${ }^{456}$ Both Kuwattalla and Šilalluhi might be from Kizzuwatna. ${ }^{457}$

She might be the same ritualist who is mentioned in a passage in Hurrian in KBo 5.2 (II 22-23), ${ }^{458}$ "Ritual of Ammihatna"; here we read: šilalluhi šala Tupkia=ve "Šilalluhi, daughter of Tupkiya". Since silalluhi appears in some Hittite texts also as an appellative, R. Strauss believes that šilalluhi is here an apposition to the divine name ${ }^{\mathrm{D}}$ Imbutte, that precedes it in the text. ${ }^{459}$ In my opinion, since the name of her father, Tupkiya, is mentioned, I prefer the hypothesis that Šilalluhi refers to the Hurrian ritualist, author of the words pronounced by Ammihatna. Since also the Ammihatna ritual goes back the the Early

\footnotetext{
${ }^{448}$ See Haas - Wegner 1988, 208-232; Giorgieri 1998, 71-86.

${ }^{449}$ See Haas - Wegner 1988, 13; Zehnder 2010, 262 with literature.

${ }^{450}$ Haas 1971, 139.

${ }^{451}$ See Christiansen 2006, 11.

452 See Starke 1985, 117.

453 See Starke 1985, 116-117.

${ }^{454}$ See Starke 1985, 95-96.

${ }^{455}$ See Starke 1985, 91-92.

${ }^{456}$ See Hutter 2003, 253.

${ }^{457}$ See Yakubovich 2010, 18.

${ }^{458}$ See Strauss 2006, 224-225.

${ }^{459}$ Strauss 2001, 410.
} 
Imperial Age, ${ }^{460}$ it is presumable that all these texts mention the same Hurrian "Old Woman" and expert of rituals Šilalluhi. ${ }^{461}$

Šilalluhi is a Hurrian name that contains the root $\check{s i l}-^{462}$ (šil $=a l_{-}{ }^{463}$ $\left.o=\dot{g} e / h h e^{464}\right)$. This same root can been recognized in other Hurrian names as Šilallu (Tell al-Rimah) ${ }^{465}$ and Šilahi (Nuzi). ${ }^{466}$

Her father's name, Tupkiya, is often documented in the Nuzi texts ${ }^{467}$ and is known also by other textual evidence (Tell al-Rimah; ${ }^{468}$ Mari: Tupki $\left.^{469}\right) .{ }^{470}$

Taguya:

Together with Ašnu-Nikkali and Ammihatna, he is "author" of the ritual KUB 9. 2. ${ }^{471}$

This hypocoristicon name, that comes from the Hurrian verb tag- "to light, to shine", ${ }^{472}$ is documented also at $\mathrm{Nuzi}^{473}$ and it was quite common at Alalah. ${ }^{474}$

${ }^{460}$ See Strauss 2006, 219.

${ }^{461}$ So Zehnder 2010, 271; for Ššsilalluhi mentioned in KBo 41. 214 III 4', 14' see Haas 2008, 89.

${ }^{462}$ See Neu 1996, 63 n. 12; Prechel - Richter 2001, 361 and n. 158.

${ }^{463}$ For the root complement - al see Giorgieri 2000a, 196-197; and Wegner 2007, 87.

${ }^{464}$ For the suffix $-o=\dot{g} e /$ hhe, see Giorgieri 2000a, 206-209; Wegner 2007, 54.

${ }^{465}$ See Sasson 1979, 46.

${ }^{466}$ See Gelb - Purves - MacRae 1943, 133; Cassin 1977, 127.

${ }^{467}$ See Gelb - Purves - MacRae 1943, 158; Cassin 1977, 150.

${ }^{468}$ See Sasson 1979, 47.

${ }^{469}$ See Sasson 1974, 370.

${ }^{470}$ For the word tupk- and for other names composed with it see Salvini 1996b, 84-86.

${ }^{471}$ See Strauss 2006, 274-276.

472 See Giorgieri 2000a, 406.

${ }^{473}$ Gelb - Purves - MacRae 1943, 145; Cassin 1977, 138.

${ }^{474}$ See Draffkorn 1959, 54; von Dassow 2008, 567. 
Tulbi(ya):

Tulbi(ya), Ammihatna and Madi purapši- priests from Kummani are the "authors" of the ritual KBo 23. $1+\mathrm{I} 1,{ }^{475}$ that we have already mentioned.Tulbi(ya) appears also in some catalogue entries: ${ }^{476} \mathrm{KBo}$ $31.4+\mathrm{V}$ 21'- 28', together with Naniyanni, Madi, Ammiyatala, Pabanikki $=$ Paba-nigri, all from Kummani; ${ }^{477}$ KBo 31. $27+$ II 5'-7', with Ammihatna and Madi; ${ }^{478}$ KUB $31.8+$ IV 25-29, together with Ammihatna and Madi; ${ }^{479}$ KUB 30. 51+ II 3' -6 ', ${ }^{480}$ with Ammihatna and

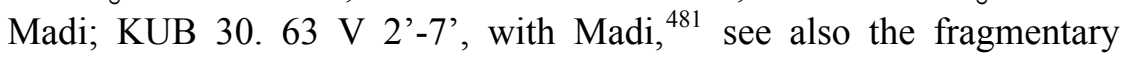
passage $\mathrm{V} 12$ '.

Tulbi/Tulbiya is a hypocoristicon name; ${ }^{482}$ the Hurrian root tulb- is very productive in personal names as the texts of Nuzi (Tulbiya; Tulbi-šenni; Tulbi-Šarri), ${ }^{483}$ Alalah (Tulbi; Tulbiya; Tulburi), ${ }^{484}$ Emar (Tulburi; Tulba'e) ${ }^{485}$ show. ${ }^{486} \mathrm{M}$. Salvini ${ }^{487}$ has proposed that the root $t u l b$ - might be connected to the root tupk- that is known from the name of the ruler of Urkiš, Tupkiš; according to this scholar, the meaning of tulb- might be "to cause to prosper".

Imperial Age:

fikkal-uzzi:

A magic ritual is performed by Nikkal-uzzi in the tablet KBo $49.28+7$. 61; in this ritual two figurines (ALAM) are prepared; the name of the

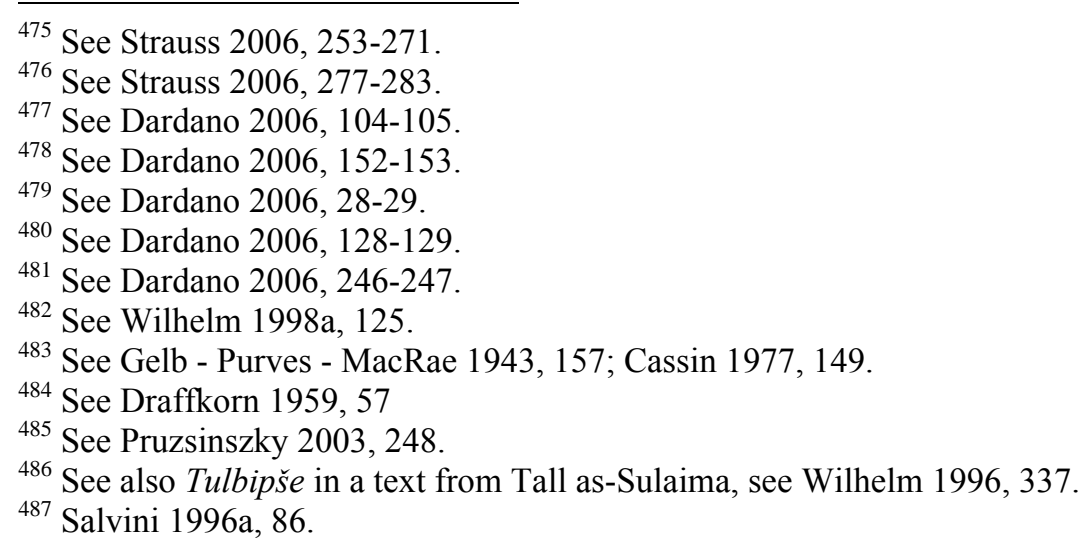


enemy of the king is written on one of them, and that of BU-Šarruma on the other one. M. Hutter ${ }^{488}$ believes that this BU-Šarruma is the son of Tuthaliya I/II, but - as M. Giorgieri ${ }^{489}$ has recently observed - this text hardly belongs to the Early Empire and it seems to be later.

This name contains the divine name Nikkal; it might be a Hurro-Luwian name, since this second element $-u z z i$ can be connected to the Luwian word wa/izi- (in Hier. Luw. it is written with the logogram IR) ${ }^{490}$ the meaning of this name might be "Nikkal-wished". 491

\section{f̌̌abšušu:}

This name appears in the colophon of the fragmentary text KUB 47. 49, that contains recitations in Hurrian; even if the colophon too is fragmentary, we can presume that the mention of Kizzuwatna in the line IV 8' refers to the country from where Šabšušu comes. We do not know anything about the time when Šabšušu lived, a part the fact that KUB 47. 49 is a late imperial tablet.

The etymology of this name is obscure. ${ }^{492} \mathrm{~V}$. Haas - H.J. Thiel quote names such as Šapši and Šapše that are documented at Alalah, ${ }^{493}$ we can add another name from Alalah: Šapši-Adu. ${ }^{494} \mathrm{~V}$. Haas has proposed the translation "Sonnenscheibe(?)" for the Hurrian word šapši $i{ }^{495}$ that might be connected to these names; for the suffix $-\check{s} u$ see here s.v. Šalašu.

${ }^{\mathrm{f}}$ Ummaya:

Ummaya ${ }^{496}$ is the "author" of the ritual KBo 15.1 II 5 'ff., ${ }^{497}$ where she recites in Hurrian. This ritual was performed for the King Muršili II.

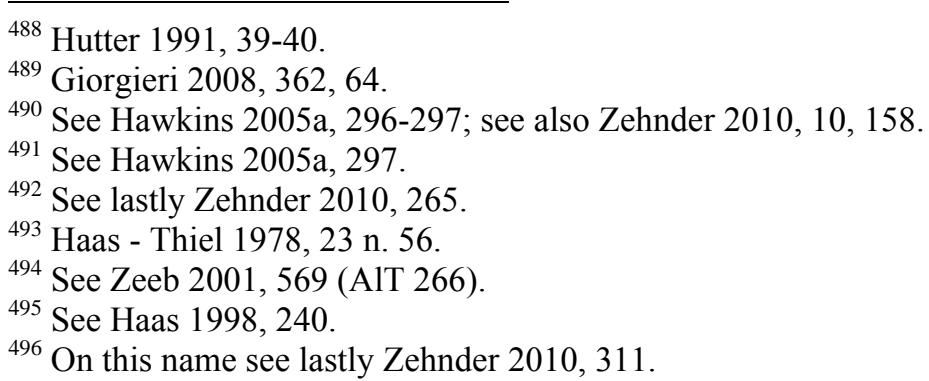


The Hurrian part of this text was copied also in two other tablets, where the name Tašmi-Šarruma (= Tuthaliya $\mathrm{IV}^{498}$ ) appears. ${ }^{499}$

This name can be confronted with other Hurrian names as Ummi, Ummiya, Ummai (Nuzi). As Th. Zehnder observes, this name might be connected either to a Hurrian word *umma- "mummy, mother"500 or to the Akkadian word ummu(m) "mother". 501

\subsubsection{Diviners}

Early Empire (?):

Ehal-Tešob:

$\mathrm{He}$ is mentioned, as an expert of divination ( $\left.{ }^{\mathrm{L}} \mathrm{HAL}\right)$ from Aleppo and as author of rituals, in some catalogues of tablets, ${ }^{502}$ that might refer to texts of the time of Arnuwanda I, Tuthaliya III ${ }^{503}$ or Šuppiluliuma I. ${ }^{504}$ According to D. Hawkins $(2005,254-253)$ this diviner might be the same individual, whose seal is documented by an impression preserved in the archive of Nişantepe (no. 104) where he has the title SACERDOS $_{2}{ }^{505}$

This name presumably is a different spelling of Ehel-Tešob $=$ EhliTešob $(e \dot{g} e l<e \dot{g} l=i-T e s ̌ o b) .{ }^{506}$

\footnotetext{
497 See Haas - Wegner 1988, 233-247.

${ }^{498}$ See $\S 2.2$.

${ }^{499}$ See Haas - Wegner 1988, 16, 240-247.

${ }^{500}$ See G. Wilhelm apud Haas - Wegner 1988, 15 n. 2

${ }^{501}$ Zehnder 2010, 311.

${ }^{502}$ See Dardano 2006, 130-131, 152-153, 212-213.

${ }^{503}$ See Miller 2004, 388 n. 616.

${ }^{504}$ See Miller 2004, 506 n. 925.

${ }^{505}$ See Herbordt 2005, 131.

${ }^{506}$ See Giorgieri 2000b, 288; for ègli see p. 37.
} 


\subsubsection{Experts of Medicine}

Early Empire (?):

Agiya:

He is mentioned as "physician" ( $\left.{ }^{\mathrm{L}} \mathrm{A} . \mathrm{ZU}\right)$, together with his colleague Hudubi, in the deposition of a certain Kukkuwa in the court proceeding KUB 34. $45+$ KBo 16. 63 Obv. 12' ${ }^{507}$ Kukkuwa got sick and two physicians, Agiya and Hudubi, took care of him. In this same text also 'Šaušgatti is mentioned, but according to Th. van den Hout ${ }^{508}$ she cannot be the same personage who is known as the wife of Arma-Tarhunta, since KUB 34. 45 shows "an older script". ${ }^{509}$

f Azzari:

According to two catalogues of tablets, KBo $31.8+$ I $8^{510}$ and KUB 30 . $51+$ IV 17, ${ }^{511}$ Azzari, ${ }^{512}$ Hurrian expert of medicine $\left({ }^{\text {MUNUS }}\right.$ A.ZU ${ }^{\text {(URU) }}$ Hurlaš), ${ }^{513}$ was the "author" of two rituals. Unfortunately the rituals, that these two entries refer to, have not arrived to us.

We do not know when Azzari lived; since the other Hurrian physicians mentioned in Hittite texts seem to belong to the Early Imperial Age, that is when the works of many Kizzuwatnean and Syrian experts of rituals started to be known at the Hittite court, we might suppose that also Azzari's rituals were imported in the $14^{\text {th }}$ century.

${ }^{507}$ See Werner 1967, 50-51.

${ }^{508}$ Van den Hout 1998, 64-65; see also Košak-web site.

${ }^{509}$ See also Košak-web site; Marizza 2007, 74. On the contrary Other scholars do not consider the ductus of this text as "Middle Hittite", see the literature quoted by Alaura 1999, 492, 17.

${ }^{510}$ See Dardano 2006, 22-23.

${ }^{511}$ See Dardano 2006, 132-133.

512 See also Bo 3203 obv. 19' (Dardano 2006, 270); KBo 42.13 obv. 5'.

513 See Otten - Rüster 1993, 539-541. 
This name can be interpreted as an imperative ${ }^{514}$ from the verbal root $a z-{ }_{-}^{515}$ ( + the root complement $-a r-{ }^{516}$ ). This root can be found in other Hurrian personal names. ${ }^{517}$

Hudubi:

Together with Agiya he appears in KUB 34. $45+$ KBo 16. 63 Obv. 12' (see here s.v. Agiya). He is said to be a "physician" ( $\left.{ }^{\mathrm{L}} \mathrm{A} . \mathrm{ZU}\right)$.

This personal name ${ }^{518}$ might be connected to the Hurrian verbal root hud- "to praise", ${ }^{519}$ that is documented also in several names in Nuzi (as for example Hudib-Šarri, Hudib-Tilla, Hudib-Tešob, Hudiya etc.). ${ }^{520}$

${ }^{514}$ For Hurrian names of this type see Wilhelm 1998a, 123.

${ }^{515}$ See $\S$ 4.4.8. s. v. Azziya.

${ }^{516}$ See Giorgieri 2000a, 197; Wegner 2007, 88.

${ }^{517}$ See de Martino - Giorgieri 2008, 154-155.

${ }^{518}$ See also Zehnder 2010, 78 n. 109.

519 In fact in the "Song of Release" KBo 32. 19 Obv. I 14 // II 15 the Hurrian verb hud-corresponds to the Hittite verb šarliye-/̌̌arlai- (on this verb see CHD Š, 273-274); see also Haas - Wegner 1996, 289 “segnen” and lastly Wegner 2007, 261 "beten, preisen".

${ }^{520}$ See Gelb - Purves - MacRae 1943, 64-66; Cassin 1997, 61-64. 


\subsubsection{Other or Unknown Professions}

\section{Early Empire:}

\section{Agiya 1:}

He is mentioned in KUB 23. $68+$ rev. $19,{ }^{521}$ Treaty of Arnuwanda I with people (= military colonists $?)$ mostly from Išmeriga.

\section{Agiy[a 2:}

A man by this name belongs to the personnel of a household in the land grant of Arnuwanda I and Ašmu-Nikkal KBo 5.7 obv. $24 .^{522}$

Ali-p/wašu:

He appears in the already mentioned treaty of Arnuwanda I with the people of Išmeriga (KUB 23. $68+$ rev. $17^{523}$ ).

This name might come from the Hurrian verbal root al- "to speak; to say"; ${ }^{524}$ since the second element of the name might be connected to the Hurrian word paži "mouth", 525 this name might mean "the/(his) mouth says" $(a l=i(=b)$ - paži $)$. Differently, according to Th. Zehnder $(2010,74)$ Ali-wašu might be a Hurro-Luwian name and wašu could be interpreted as a Luwian word.

\footnotetext{
${ }^{521}$ See Kempinski - Košak 1970.

${ }^{522}$ See Riemschneider 1958, 344.

${ }^{523}$ See Kempinski - Košak 1970, 198-199.

${ }^{524}$ See lastly de Martino - Giorgieri 2008, 52-53.

${ }^{525}$ See André-Salvini - Salvini 1998, 22: waši
} 


\section{${ }^{\mathrm{f}}$ Azziya:}

In the land donation of Arnuwanda I and Ašmu-Nikkal KBo 5. $7^{526}$ a woman named Azziya (rev. 28) is listed among the personnel of the "house" of a certain Tiwatapara.

This name is documented also at $\mathrm{Nuzi}^{527}$ and at $\mathrm{Emar}^{528}$ as a masculine name. As we have already said, the root $a z-$, of unknown meaning, can be found in several other Hurrian personal names. ${ }^{529}$

Ehalte:

In the already mentioned treaty of Arnuwanda I with the people of Išmeriga KUB 23. $68+$ rev. $13^{530}$ we find an individual from Išmeriga who has the hypocoristicon name Ehalte (=Ehal-Tešob), see $\S$ 4.4.6.3 s.v.

Hurlanni:

In the treaty of Arnuwanda I with the people of Išmeriga, that we have already quoted several times, also a certain Hurlanni is mentioned (KUB 23. 68 rev. 18).

This name ${ }^{531}$ might contain the word hurla "Hurrian", that is well known in the Hittite sources ${ }^{532}$ and the Hurrian suffix -nni; otherwise it might be a Hurro-Hittite composed with the suffix -wanni (in this case we might suggest an original form *Hurluwanni), that we find in some personal names composed with a geographical name. ${ }^{533}$

${ }^{526}$ See Riemschneider 1958, 350-351.

${ }^{527}$ See Zehnder 2010, 136.

${ }^{528}$ See Pruzsinszky 2003, 249.

${ }^{529}$ See lastly de Martino - Giorgieri 2008, 154-155.

${ }^{530}$ See Kempinski - Košak 1970, 196-197.

${ }^{531}$ For the possible etymologies of this name see de Martino 2010b, 138-139; Zehnder 2010, 14.

${ }^{532}$ See Tischler 1976, 304-305.

${ }^{533}$ See Hoffner 1998, 118. 
fYaru-Heba:

This woman takes part in the ritual KUB 60. 121 rev. 18; M. Popko $(1991,239)$ dates this ritual to the fourteenth century and considers it of Hurrian inspiration (see for example the presence of the word anahi, obv. 20').

This uncommon name might be composed with a verbal root ${ }^{534}$ connected to the word iari that is documented in some fragmentary Hurrian passages. ${ }^{535}$

Kumarbi:

He is mentioned in KBo 16. 42 rev. 18', 20'; this text might refer to the situation of eastern Anatolia at the time of Arnuwanda I and Tuthaliya III. ${ }^{536}$

Nani:

A person named Nani, who comes from the Išmeriga, is mentioned in the treaty of Arnuwanda I with the people of this country (KUB 23. 68 rev. 17).

As we have already said (see $\S 4.4 .6 .1$. s.v. Naniya), the names Nani and Naniya are documented at $\mathrm{Nuzi}^{537}$ and Naniya also at Alalah. ${ }^{538}$

fPattiyanni:

Following Th. Zehnder we can read so the personal name documented in KBo 5.7 obv. $22^{539}$ (land grant of Armuwanda I and Ašmu-Nikkal), that K. Riemschneider reads Pittiyanni. ${ }^{540}$

\footnotetext{
${ }^{534}$ See also Zehnder 2010, 171.

${ }^{535}$ See Röseler 1999, 400.

${ }^{536}$ See lastly Torri 2005, 396-397.

${ }^{537}$ See Gelb - Purves - MacRae 1943, 103; Cassin 1977, 97.

${ }^{538}$ See von Dassow 2008, 293.
} 
Pattiyanni can be connected to the Hurrian personal name Pattiya (see $\S$ 2.2.); differently from Th. Zehnder, who considers Pattiyanni "ein luwisches Hypokoristikon zum hurritischen Namen ${ }^{\mathrm{f}}$ Pattiya", ${ }^{541}$ in my opinion the whole name can be interpreted as authentically Hurrian and we can compare for example names as Tuliya and Tuliyanni (Nuzi). ${ }^{542}$

Purazi:

This individual is mentioned in a group of six workers assigned to the royal palace in the tablet from Maşat HKM 100 (obv. 11'). ${ }^{543}$

This name contains the suffix $-(a)=\check{s} \check{s} e /-z ̌ i /-z i^{544}$ and, presumably, the word pura that can be connected to pura=me "slave".

Early Empire or beginning of the Imperial Age (?):

Šarrup-šena:

He is mentioned in the court proceeding KBo 16.59 obv. 15 ' [, 1.e. $2 .^{545}$ According to Th. van den Hout the ductus of this tablet cannot be of the $13^{\text {th }}$ century and looks older. ${ }^{546}$

This name can be translated as "the/his brother desired him" $(\check{s} a r=o=p(<m)-\check{s} e n(a)) .{ }^{547}$

${ }^{539}$ Zehnder 2010, 247.

${ }^{540}$ Riemschneider 1958, 345.

${ }^{541}$ Zehnder 2010, 247.

${ }^{542}$ See Gelb - Purves - MacRae 1943, 157; for the suffix $-a=n n i$ see Giorgieri 2000a, 211

${ }^{543}$ See del Monte 1995, 98-99.

${ }^{544}$ See Giorgieri 2005a, 202-204.

${ }^{545}$ See Werner 1967, 53-55.

${ }^{546}$ van den Hout 1995, 225.

${ }^{547}$ For $m+\check{s}>p \check{s}$ see Giorgieri 2005b, 287. 
Imperial Age:

${ }^{\mathrm{f}} \mathrm{Ašdu}:$

In the text KBo 10. 10 III 37 (list of zintuhi-) she is said to be "servant of Duayali". 548

On this name see $\S 4$ 4.6.6.2. s.v.

Ibri-LUGAL-ma (= Evri-Šarruma):

A child (DUMU.NITA) by this name appears in KUB 31. $52+$ (StBoT 1 I 22) "Vow of Pudu-Heba"; he is a member of one of the "houses" given by the Queen Pudu-Heba to the deity Lelwani.

On this name see $\S 4.4 .1$. s.v. Evri-Šarruma.

${ }^{\mathrm{f}}$ Hebate/i: ${ }^{549}$

She appears in KUB 52. 15 II 7, III 1'; as Ph. Houwink ten Cate (1994, 252) has noted, this fragmentary tablet deals with matters concerning the cult and temples. We do not know what role she fulfilled. ${ }^{550}$

This name is documented also at Emar. ${ }^{551}$ Concerning the etymology of this name, Hebate might be the genitive Hebat $=v e>$ Hebatte $^{552}$ and it might mean "(the child) of Hebat".

${ }^{548}$ See Rutherford 2004, 391.

${ }^{549}$ See Zehnder 2010, 157.

${ }^{550}$ Houwink ten Cate 1994, 252, n. 60, reads the name as Heba-piya; for the correct reading Hebati see de Roos 1998, 161.

${ }^{551}$ See Pruzsinszky 2003, 241; see also Trémouille 1997, 234.

${ }^{552}$ See Giorgieri 1999, 240-241. 


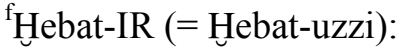

This is a Hurro-Luwian name. The reading of the logogram IR is uzzi-; this onomastic element can be connected to the Hier. Luwian stem wa/izi-; ${ }^{553}$ the meaning of this name might be: "Hebat-wished". ${ }^{554}$

Hebat-uzzi is mentioned in the list of garments KUB 42.49 obv $9 ;{ }^{555}$ it is not clear whether these garments have been given or received by her. ${ }^{556}$

${ }^{\mathrm{f}}$ Huiya: ${ }^{557}$

A seal impression from Nişantepe (no. 132) ${ }^{558}$ preserves the name HWIi(a)-á and the title FEMINA. As D. Hawkins observes, this name can be confronted with the masculine Huiya ${ }^{559}$ that is documented in "Muršili II's Dictate to Tuppi-Tešob's Syrian Antagonists". 560

It is a hypocoristicon name that might come from the Hurrian verb hu(i)- "to cry". ${ }^{561}$

Hudu-Tešob:

He is mentioned in KUB 31. 59 III 32 (List of families).

This name can be analyzed as hud=u-Tešob "Tešob has praised him". ${ }^{562}$

${ }^{553}$ See Hawkins 2005a, 296-297; see also Zehnder 2010, 10, 158.

554 See Hawkins 2005a, 297; Zehnder 2010, 158: “(erfüllter) Wunsch an Hepat".

${ }^{555}$ See Košak 1982, 127-128; Siegelová 1986, 347-349.

${ }^{556}$ See Siegelová 1986, 347.

${ }^{557}$ See Zehnder 2010, 162.

${ }^{558}$ See Herbordt 2005, 136.

${ }^{559}$ Hawkins 2005a, 256.

${ }^{560}$ See Beckman 1996, $156 \S 7$; for this text see now Miller 2007.

${ }^{561}$ See Wegner 2001, 443; Wegner 2007, 261.

${ }^{562}$ Cfr. the name Hudib-Tešob, for which see Wlhelm 1996, 182 “(Le dieu) Teššub a fait monter". 
${ }^{f}$ Kuzi:

In the ritual KUB 55. $54+$ I $14{ }^{, 563}$ Kuzi and her sons are the receivers of an offering. They might be dead persons. A. Ünal $(1987,85)$ wonders whether they might belong to the royal family.

For other names composed with the verbal root kuz- see $\S$ 4.4.5. s.v. Kuzi-Tešob.

\section{Madi-Šarruma:}

He is mentioned in the tablet KBo 22.29 r. c. 3, $5,{ }^{564}$ that seems to be a court proceeding. According to L. Mascheroni ${ }^{565}$ this same personal name could be read on the fragmentary seal impression SBo II 68 where the owner of the seal has the title MAGNUS SCRIBA, but according to S. Herbordt ${ }^{566}$ the name of the holder of this seal has to be read as Pendi-Šarruma.

This name can be interpreted as "Šarruma (is) wise", if we take madi as an adjective $e^{567}$ or "Šarruma (is) wisdom", if we understand it as a noun. ${ }^{568}$

Nigri-Tešob:

This name is borne by an individual, who receives clothes and precious objects in the inventory text KUB 42.84 obv. $11-14 .{ }^{569}$ We do not know for which reasons Nigri-Tešob is the receiver of these goods and what is his social condition. ${ }^{570}$

\footnotetext{
${ }^{563}$ See Groddek 2002, 96-99.

${ }^{564}$ See Groddek 2008, 34-35.

${ }^{565}$ Mascheroni 1984, 152 n. 7.

${ }^{566}$ Herbordt 2005, 171.

${ }^{567}$ For madi as an adjective see Volk 2004, 91.

${ }^{568}$ See Wegner 2000, 49; Giorgieri 2000b, 290,

${ }^{569}$ See Košak 1982, 154-156; Siegelová 1986, 124-129.

${ }^{570}$ See Siegelová 1986,124-125.
} 
His name is composed with the Hurrian word nigri "bolt", ${ }^{571}$ that appears also in the name Paba-nigri; it is translated by Th. Richter as: "Der Götterkönig/Gott Teššup ist (wie) ein Riegel". ${ }^{572}$

Nulaya:

He is mentioned in the very fragmentary letter KBo 18.140 rev. $12^{\prime} ;^{573}$ we do not know anything concerning this individual and his activities.

Th. Zehnder considers this name as Hurrian. ${ }^{574}$ It is a hypocoristicon name that contains the verbal root $n u l$ - that appears in personal names as Nul-Tešob and Nulliya (Nuzi). ${ }^{575}$

Pandiya:

$\mathrm{He}$ is mentioned in the fragmentary tablet KUB 15. 12 (IV 9'), that reports dreams of the queen. ${ }^{576}$

In this hypocoristicon name we can recognize the Hurrian verb $f / p a / e n d-$ "to be right; to bring to the right condition". ${ }^{577}$ This name is documented in the Tell al-Rimah ${ }^{578}$ tablets, at Mari ${ }^{579}$ and Alalah; ${ }^{580}$ it was popular at Nuzi, where we find many men by this name ${ }^{581}$ (see also $\S$ 4.4.6.1. s.v. Pendib-šarri). ${ }^{582}$

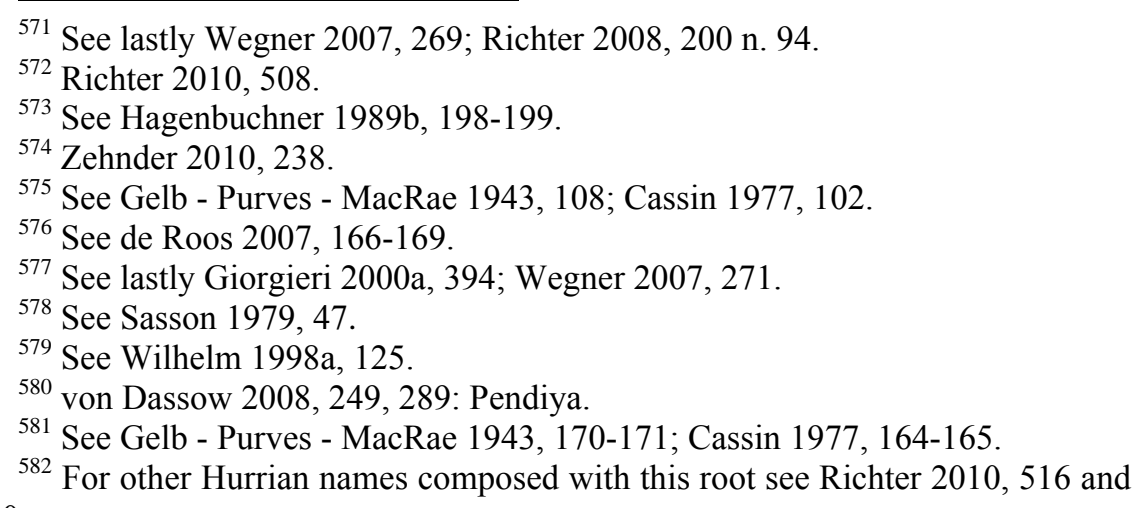
n. 50 . 
Šaušga-Runtiya 1:

He releases two declarations in the court proceeding KUB 31. $76+$ KUB 40. 88 III 19', ]21'; ${ }^{\prime} 58$ since here the name if his father is mentioned (ARAD-li = Hutarli), obviously he cannot be the "Prince of Tarhuntašša", ${ }^{584}$ of whom we have already written (see $\S 3$.).

Šaušga-Runtiya 2:

$\mathrm{He}$ is the holder of a seal the impression of which has been found in the Hittite capital; here he has only the title $\mathrm{VIR}_{2} .{ }^{585}$

f̌́aušgatti ( ${ }^{\mathrm{D} I S \zeta T A R-a t t i) ~ 1: ~}$

In the "Vow of Puduheba to Lelwani" (I 13) ${ }^{586}$ a women by this name, daughter of ${ }^{\mathrm{f}}$ Mamma, is mentioned. ${ }^{587}$

f̌́aušgatti ( ${ }^{\mathrm{D} I S \zeta T A R-a t t i) ~ 2: ~}$

Another women by this same name appears in another passage of the "Vow of Puduheba to Lelwani" (IV 15).

Šaušga-ziti:

A seal impression from the Hittite capital preserves this personal name. ${ }^{588}$ The holder of this seal has only the title $\mathrm{VIR}_{2}$. We can presume that he is not the same official who is mentioned in some court proceedings (see 4.4.1 s.v.), since the latter was a dignitary of high rank

\footnotetext{
${ }^{583}$ See Werner 1967, 24-25.

${ }^{584}$ See also Marizza 2006, 167.

${ }^{585}$ See Dinçol - Dinçol 2008, 44, no. 178.

${ }^{586}$ See Otten - Souček 1965, 16-17.

${ }^{587}$ On this name see Zehnder 2010, 269.

${ }^{588}$ See Dinçol - Dinçol 2008, 53, no. 244.
} 
(even if we cannot say anything more precise) and close to the royal family.

Taguhili:

He is mentioned in a fragmentary context in the tablet KUB 26. 92, 18', that some scholars consider a letter, ${ }^{589}$ whereas Ph. Houwink ten Cate has recently proposed that it is a court proceeding. ${ }^{590}$ This text can be dated to the second half of the $13^{\text {th }}$ century thanks to the mention of Bentešena (king of Amurru) and Tattamaru. According to I. Singer (1983, 11-13) this Taguhili could be the same as Takuhlinu governor of Ugarit. $^{591}$

This name $(\operatorname{tag}=o=\dot{g}(e)=l i)$, that is documented also in the historiographic fragment KUB 26. 85 (it is borne by a Mittanian general) ${ }^{592}$ presents the Hurrian verb tag- "to light, to shine" and the suffix that usually forms nouns of professions. ${ }^{593}$

Tagup-šeni:

This name is documented in the ritual KBo $22.114,{ }^{594} 7^{\prime}$; since the passage is fragmentary we do not have any information on this man.

Tagup-šeni $(\operatorname{tag}=o=p(<m)$ - $\check{s} e n(a))$ is composed with the verb tag- "to light, to shine" and with the word šen $(a)$ "brother".

\footnotetext{
${ }^{589}$ See Hagenbuchner 1989b, 398-405.

${ }^{590}$ See Houwink ten Cate 2006, 3-4.

${ }^{591}$ On this high official see Singer 1983, 6-18.

${ }^{592}$ See del Monte, 2008, 165-166.

${ }^{593}$ See Wilhelm 1998a, 126; Giorgieri 2005a, 210 ("tedoforo"?).

${ }^{594}$ See lastly Groddek 2008, 106 with previous literature.
} 
Talmi-Tešob:

An individual by this name ${ }^{595}$ is in the fragment KBo 16. 22 obv. 1', that mentions also Šippaziti, the well know person, son of ArmaTarhunta, both opponents of Hattušili III. ${ }^{596}$

${ }^{595}$ See van den Hout 1995, 164.

${ }^{596}$ See van den Hout 1995, 235-239. 



\section{BIBLIOGRAPHICAL REFERENCES}

Alaura 1999

Alp 1998

André-Salvini -

Salvini 1998

Archi 1994

Archi - Klengel 1985

Bawanypeck 2005

Bawanypeck -

Görke 2007

Beal 1992

Beal 2002

Beal 2003

Beckman 1996

Bemporad 2002

Cammarosano 2009
S. Alaura, Rev. of Th. VAN DEN Hout 1998, OLZ 94, 484-494.

S. ALP, "Zur Datierung des Ulmitešup-Vertrags", AoF 25, 54-60.

B. ANDRE-SAlvinI - M. SAlvinI, "Un nouveau vocabulaire trilingue sumérien-akkadien-hourrite de Ras Shamra", SCCNH 9, 3-40.

A. ARCHI, "Studies in the Pantheon of Ebla", Orientalia 63, 249-256.

A. ARCHI - H. KLENGEL, "Die Selbstrechtsfertigung eines hethitischen Beamten", AoF 12, 52-64.

D. BAWANYPECK, Die Rituale der Auguren (THeth 25), Heidelberg.

D. BAWANYPECK - S. GÖRKE, "Einige Bemerkungen zu den hurritischen Sprüchen des Giziya-Rituals", in: D. GRODDEK - M. ZORMAN (eds.), Tabularia Hethaeorum (DBH 25), Wiesbaden, 59-68.

R. BEAL, The Organisation of the Hittite Military (THeth 20), Heidelberg.

R. BEAL, "The Hurrian Dynasty and the Double Names of Hittite Kings", in: S. DE MARTINO - F. PECCHIOLI DADDI (eds.), Anatolia Antica (Eothen 11), Firenze, 55-70.

R. BEAL, "The Predecessors of Hattušili I", in: G. BECKMAN - R. BEAL - G. MCMAHON (eds.), Hittite Studies in Honor of Harry A. Hoffner Jr., Winona Lake, 13-45.

G. BeCKMAN, Hittite Diplomatic Texts, Atlanta.

A. BEMPORAD, "Per una riattribuzione di KBo 4. 14 a Šuppiluliuma II", in: S. DE MARTINO - F. PECCHIOLI DADDI (eds.), Anatolia Antica (Eothen 11), Firenze, 71-86.

M. Cammarosano, “A Coregency for Muršili III?”, AoF 36, 171-202. 
Cammarosano 2010

M. Cammarosano, "Tanuhepa: A Hittite Queen in Troubled Times", Mesopotamia 45, 47-64.

Cancik-Kirschbaum 1996 E. CANCIK-KIRSCHBAuM, Die mittelassyrische Briefe aus Tall Šèh Hamad, Berlin.

Carruba 2000

O. CARrubA, "Tawananna II", in: S. GraZIANI (ed.), Studi sul Vicino Oriente Antico, Napoli, 71-83.

Carruba 2008

O. Carruba, Annali Etei del Medio Regno (StMed 18), Pavia.

Cassin 1977

E. CASSIN, Anthroponymie et Anthropologie de Nuzi, Malibu.

Christiansen 2006

B. Christiansen, Die Ritualtradition der Ambazzi (StBoT 48), Wiesbaden.

Christiansen 2007

B. Christiansen, "Ein Entsühnungsritual für Tuthaliya und Nikalmati? Betrachtungen zur Entstehungsgeschichte von KBo 15.10+", SMEA 49, 93-107.

Cohen 2010

Y. COHEN, "Shortened Names in Emar and Elsewhere on the Basis of Cuneiform and Hittite Hieroglyphic Evidence“, in: I. SINGER (ed.), ipamati kistamati pari tumatimis. Luwian and Hittite Studies Presented to J. David Hawkins on the Occasion of his 70th Birthday, Tel Aviv, 32-43.

Dardano 2006

von Dassow 2008

P. DARDANO, Die hethitischen Tontafelkataloge aus Hattuša (CTH 276-282) (StBoT 47), Wiesbaden.

E. VON DASSOW, State and Society in the Late Bronze Age Alalah under the Mittani Empire (SCCNH 17), Bethesda.

Devechi 2010 E. DEVECCHI, “ "We are all descendants of Šuppiluliuma, Great King'. The Aleppo Treaty Reconsidered", WO 40, $1-27$.

Dinçol 1993

A. DINÇOL, "Interessante Beispiele von Schreibersiegeln aus Boğazköy", in: M.J. MELlinK - E. PORADA - T. ÖzGÜÇ (eds.), Aspects of Art and Iconography: Anatolia and its Neighbors, Ankara, 127-130.

Dinçol - Dinçol 2008 A. DINÇOL - B. DinçOL, Die Prinzen- und Beamtensiegel aus der Oberstadt von Boğazköy-Hattuša vom 16. Jahrundert bis zum Ende der Grossreichszeit, Mainz, 2008. 
Dinçol - Dinçol -

Hawkins -

Wilhelm 1993 A. DinÇOL - B. DinÇOL - J.D. HAwKInS - G. WiLHELM, "The 'Cruciform Seal' from Boğazköy-Hattusa", IM 43, 87-106.

Doğan-Alparslan 2007 M. DoĞAN-AlParslan, "Drei Schreiber, Zwei Könige”, SMEA 49, 247-257.

Draffkorn 1959 A. DRAFFKORN, Hurrians and Hurrian at Alalah: an Ethno-Linguistic Analysis, PhD Dissertation, University of Pennsylvania.

Durnford 2010

S.P.B. DURNFORD, "How old was the Ankara Silver Bowl when its inscriptions were added?", AnSt 60, 51-70.

Edel 1994

E. EDEL, Die ägyptisch-hethitische Korrespondenz, Opladen.

Ehringhaus 2005

E. EHRINGHAUS, Götter, Herrscher, Inschriften, Mainz.

Finkel 1988

I. FINKEL, "Inscriptions from Tell Brak 1985", Iraq 50, 83-86.

Forlanini 2004

M. FORLANINI, "Considerazioni sullo spostamento del centro di potere nel periodo della formazione dello stato hittita", in: M. MAZOYER - O. CASABONNE (eds.), Antiquus Oriens, Paris, 249-269.

Forlanini 2008

M. FORLANINI, "The historical geography of Anatolia in the transition from the karrum-period to the Early Hittite Empire", in: J.G. DERCKSEN (ed.), Anatolia and the Jazira During the Old Assyrian Period, Leiden, 57-86.

Forlanini 2009

M. ForlaninI, "On the Middle Kizılirmak, II", in: F. PeCChioli DAdDi - G. TORRI - C. CORTI (eds.), CentralNorth Anatolia in the Hittite Period, Roma,39-69.

Freu 2006

J. FREU, Histoire politique du royame d'Ugarit, Paris.

Freu 2007

J. FreU, Les débuts du nouvel Empire Hittite, Paris.

Fuscagni 2007

F. FusCAGNI, Hethitische unveröffentliche Texte aus den Jahren 1906-1912 in der Sekundärliteratur, Wiesbaden.

Gelb - Purves -

MacRae 1943 I.J. Gelb - P.M. Purves - A.A. MacRae, Nuzi Personal Names, Chicago. 
Giorgieri 1998

Giorgieri 1999

Giorgieri 2000a

Giorgieri 2000b

Giorgieri 2008

Giorgieri - Mora 2010

Goetze 1940

Gonnet 1968

Gordin 2010

Görke 2007

Görke 2010

Groddek 2002

Groddek 2008

Güterbock 1942
M. GIORGIERI, "Die erste Beschwörung der 8.Tafel des Šalašu-Rituals", SCCNH 9, 71-86.

M. GIORGIERI, "Die hurritischen Kasusendungen", SCCNH 10, 223-256.

M. GIORGIERI, "Schizzo grammaticale della lingua hurrica", PdP 55, 171-277.

M. GIORGIERI, “L'onomastica hurrita”, PdP 55, 278-293.

M. GIORGIERI, "Verschwörungen und Intrigen am hethitischen Hof. $\mathrm{Zu}$ den Konflikten innerhalb der hethitischen Elite anhand der historischen-juristischen Quellen", in: G. WILHELM (ed.), Hattuša-Boğazköy (CDOG 6), Wiesbaden 351-375.

M. Giorgieri - C. MORA, "Kingship in Hatti during the $13^{\text {th }}$ Century: Forms of Rule and Struggles for Power before the Fall of the Empire", in: Y. COHEN - A. GILAN J.L. Miller (eds.), Pax Hethitica (StBoT 51), Wiesbaden, 136-157.

A. Goetze, Kizzuwatna and the Problem of Hittite Geography, New Haven.

H. GonNET, "Les montagnes d'Asie Mineure d'après les texts Hittites", RHA 26, 93-171.

Sh. GordIN, "Scriptoria in the Late Empire Period Hattusa: The Case of the É GIŠ.KIN.TI", in: Y. COHEN A. Gilan - J.L. Miller (eds.), Pax Hethitica (StBoT 51), Wiesbaden, 158-177.

S. GÖRKE, "Das Ritual der Aštu (CTH 490) zwischen Tradition und kultureller Neurung", SMEA 49, 339-345.

S. GöRKE, Das Ritual der Aštu (CTH 490), Leiden Boston.

D. GRODDEK, Hethitische Texte in Transkription. KUB 55 (DBH 4), Dresden.

D. GRODDEK, Hethitische Texte in Transkription. KBo 22 (DBH 24), Dresden.

H.G. GÜTERBOCK, Siegel aus Boğazköy 2. Teil, Berlin (reprinted Osnabruck 1967). 
Haas 1971

Haas 1994

Haas 1998

Haas 2008

Haas - Thiel 1978

Haas - Wegner 1988

Haas - Wegner 1996

Hagenbuchner 1989a

Hagenbuchner 1989

Hagenbuchner-Dresel 2010 und Verfluchen (hu(wa)rt-) in der hethitischen Gesellschaft", in: J. FINCKE (ed.), Festschrift für Gernot Wilhelm, Dresden, 155-174.

Hawkins 2002

Hawkins 2005a,

Hawkins 2005b,

Hawkins in print

$\mathrm{V}$. HAAS, " $\mathrm{Zu}$ den neuen hurritischen Texten in $\mathrm{KBo}$ XIX”, SMEA 14, 136-142.

V. HAAS, Geschichte der hethitischen Religion, Leiden New York - Köln.

V. HAAS, Die hurritischen Ritualtermini in hethitischem Kontext (ChS I/9), Roma.

V. HAAS, Hethitische Orakel, Vorzeichen und Abwehrstrategien, Berlin - New York.

V. HAAS - H.J. THIEL, Die Beschwörungsrituale der Allaiturah(h)i und verwandte Texte (AOAT 31), Neukirchen-Vluyn.

V. HAAS - I. WEGNER, Der Rituale der Beschwörerinnen SAL ŠU.GI (ChS I/5), Roma.

V. HAAS - I. WEGNER, "Stern, Tag und Segen (?) im Hurritischen", SCCNH 8, 285-290

A. Hagenbuchner, Die Korrespondenz der Hethiter. 1. Teil (THeth 15), Heidelberg.

A. Hagenbuchner, Die Korrespondenz der Hethiter. 2. Teil. (THeth 16), Heidelberg.

J.D. HAWKINS, "Eunuchs among the Hittites", in: S. PARPOLA - R.M. Whiting (eds.), Sex and Gender in the Ancient Near East, Helsinki, 217-233.

J.D. HAWKINS, "Commentaries on the Readings", in: Herbordt 2005, 248-313.

J.D. HAWKINS, "A Hieroglyphic Luwian Inscription on a Silver Bowl”, Studia Troica 15, 193-204.

J.D. HAWKINS, "The Seals and the Dinasty", in: S. HerbordT - D. BAWANYPECK - J.D. HAWKins (eds.), Die Siegel der Grosskönige und Grossköniginnen auf Tonbullen aus dem Nişantepe-Archiv in Hattuša (Boğazköy-Huattuša 23), Mainz am Rhein. 
Hazenbos 2003

J. HazenBos, The Organization of the Anatolian Local Cults During the Thirteenth Century B.C., Leiden Boston.

Heinhold-Krahmer 2001 S. HeINHOLD-KRAHMER, "Zur Diskussion um einen zweiten Namen Tuthliyas IV.", in G. WILHELM (ed.), Akten des IV. Internationales Kongresses für Hethitologie (StBoT 45), Wiesbaden, 180-198.

Herbordt 2005

S. Herbordt, Die Prinzen- und Beamtensiegel der hethitischen Grossreichszeit auf Tonbullen aus dem Nişatepe-Archiv in Hattusa, Mainz am Rhein.

Hoffner 1998

Hoffner 2009

Hoffner 2010

H.A. Hoffner Jr., "Name, Namengebung. C. Bei den Hethitern", R1A 9, 119-121.

H.A. HOFFNER Jr., Letters from the Hittite Kingdom, Atlanta.

H.A. HOFFNER Jr., "The Institutional 'Poverty' of Hurrian Diviners and the entanni-Women", in: Y. COHEN - A. Gilan - J.L. Miller (eds.), Pax Hethitica (StBoT 51), Wiesbaden, 214-225.

van den Hout 1995

van den Hout 1998

TH. VAN DEN Hout, Der Ulmitešub-Vertrag (StBoT 38), Wiesbaden.

TH. VAN DEN Hout, The Purity of Kingship, Leiden Boston - Köln.

van den Hout 2009

TH. VAN DEN HOUT, "Reflections on the Origins and Development of the Hittite Tablet Collections in Hattuša and Their Consequences for the Rise of Hittite Literacy", in: F. PECCHIOLI DADDI - G. TORRI - C. CORTI (eds.), Central-North Anatolia in the Hittite Period, Roma, 71-96.

van den Hout 2010

TH. VAN DEN HOUT, “LÚDUB.SAR.GIŠ = "Clerk”, Orientalia $79,255-267$.

Houwink ten Cate 1994 PH. HouwINK TEN CATE, "Urhi-Tessub Revisited", BiOr 51, 233-259.

Houwink ten Cate 1998 PH. Houwink TEN CATE, "An alternative Date for the Sunasuras Treaty (KBo 1.5)", AoF 25, 34-53.

Houwink ten Cate 2006 PH. HouwINK TEN CATE, "The Sudden Return of UrhiTeššub to his Former Place Banishment in Syria", in: TH. VAN DEN HOUT (ed.), The Life and Times of Hattušili III and Tuthaliya $I V$, Leiden, 1-8. 
Huehnergard 1987

Hutter 1991

Hutter 2003

Imparati 1974

Imparati 1979a

Imparati $1979 b$

Kammenhuber 1976
J. Huennergard, Ugaritic Vocabulary in Syllabic Transcription, Atlanta.

M. HutTER, "Bemerkungen zur Verwendung magischer Rituale in mittelhethitischer Zeit", AoF 18, 32-43.

M. HutTer, "Aspects of Luwian Religion", in: C. Melchert (ed.), The Luwians, Leiden - Boston, 211-280.

F. IMPARATI, "Una concessione di terre da parte di Tutdhaliya IV", RHA 32, 1-209.

F. IMPARATI, "Une reine de Hatti vénère la désse Ningal", in: Florilegium Anatolicum, Paris, 169-176.

F. IMPARATI, "Il culto della dea Ningal presso gli Ittiti", in: O. Carruba (ed.), Studia Mediterranea Piero Meriggi dicata, Pavia, 293-324.

A. KAMMENHUBER, Orakelpraxis, Träume und Vorzeichenschau bei den Hethitern (THeth 7).

Kempinski - Košak 1970 A. KEMPINSKI - S. KOŠAK, "Der Išmeriga-Vertrag”, WO $5,191-217$.

Klengel 1991

H. Klengel, "Tuthaliya IV. von Hatti: Prolegomena zu einer Biographie", AoF 18, 224-238.

Klengel 1992

H. Klengel, Syria 3000 to 300 B.C., Berlin.

Klinger 1996

Klinger 2005

Klinger 2010

Kloekhorst 2008

Košak 1982
J. KLINGER, Untersuchungen zur Rekonstruktion der hattischen Kultschicht (StBoT 37), Wiesbaden.

J. KLINGER, "Die hethitische Rezeption mospotamischer Literatur und die Überlieferung des Gilgameš-Epos in Hattuša", in: D. PRECHEL (ed.), Motivation und Mechanismen des Kulturkontaktes in der Späten Bronzezeit (Eothen 13), Firenze, 103-127.

J. Klinger, "Der Kult der Ištar von Šamuha in mittelhethitischer Zeit", in: J. KLINGER - E. RIEKEN - CHR. RÜSTER (eds.), Investigationes Anatolicae (StBoT 52), Wiesbaden, 153-167.

A. KLOEKHORST, Etymological Dictionary of the Hittite Inherited Lexicon, Leiden - Boston.

S. KoŠAK, Hittite Inventory Texts (THeth 10), Heidelberg. 
Košak-web site

Lackenbacher -

Malbran-Labat 2005

Laroche 1966

Laroche 1976

Laroche 1981

Lefèvre-Novaro -

Mouton 2008

Marizza 2006

Marizza 2007a

Marizza 2007b

Marizza 2009

Marizza 2010

de Martino 2002

de Martino 2005

de Martino 2009
S. KoŠAK, Konkordanz der hethitischen Texte, www.hethiter.net.

S. LACKENBACHER - F. MALBRAN-LABAT, "Ugarit et les Hittites dans les archives de la 'Maison d'Urtenu',, SMEA 47, 227-240.

E. LAROCHE, Les Noms des Hittites, Paris.

E. LAROCHE, Glossaire de la langue Hourrite (A-L), RHA 36, Paris.

E. LAROCHE, "Le Noms des Hittites: Supplément", Hethitica 4, 3-58.

D. LefeVre-Novaro - A. Mouton, "Aux Origines de l'ichthyomancie en Anatolie ancienne", Anatolica 34, 7 52.

M. MARIZZA, "La carica di GAL DUMU ${ }^{\mathrm{MES}}$ É.GAL nel regno ittita", SMEA 48, 151-175.

M. MARIZZA, Dignitari ittiti del tempo di Tuthaliya I/II, Arnuwanda, Tuthaliya III (Eothen 14), Firenze.

M. MARIZZA, "The Office of GAL GEŠTIN in the Hittite Kingdom”, KASKAL 4, 153-180.

M. MARIZZA, Lettere ittite di re e dignitari, Brescia.

M. MARIZZA, "Le cariche di GAL DUB.SAR" ${ }^{\mathrm{MEŠ}}$ e GAL DUB.SAR.GIŠ nel regno ittita”, Mesopotamia 45, 31-46.

S. DE MARTINO, "The Military Exploits of the Hittite King Hattušili I in Lands Situated between the Upper Euphrates and the Upper Tigris", in P. TARACHA (ed.), Silva Anatolica, Warsaw, 77-85.

S. DE MARTINO, "Hittite Letters from the Time of Tuthaliya I/II, Arnuwanda I and Tuthaliya III", AoF 32, 291-321.

S. DE MARTINO, "Hatti, Mittani und Qatna - Kulturtransfer in der Bronzezeit" in: M. AL-MAQDISSI - D. MORANDI BONACOSSI - P. PfälzNER (eds.), Schätze des Alten Syrien, Stuttgart, 255-257. 
de Martino 2010a

de Martino 2010b

de Martino 2010c

de Martino, in print

de Martino -

Giorgieri 2007

de Martino -

Giorgieri 2008

de Martino -

Imparati 1998

del Monte 1995

del Monte 2008

Mascheroni 1984

McMahon 1991

Miller 2004

Miller 2006

Miller 2007
S. DE MARTINO, "The Hittite Queen Šatanduhepa", in: J. FINCKE (ed.), Festschrift für Gernot Wilhelm, Dresden, 91-98.

S. DE MARTINO, "Nomi di persona hurriti nella prima età imperiale ittita", Orientalia 79, 130-139.

S. DE MARTINO, "Ali-Šarruma, re di Išuwa”, SMEA 52, in print.

S. DE MARTINO, "Hुišni, prince of Kargamiš", in a Festschrift.

S. DE MARTINO - M. GIORGIERI, "Hurritisch ašti '(Ehe)frau', AoF 34, 126-148.

S. DE MARTINO - M. GIORGIERI, Literatur zum Hurritischen Lexikon 1 (A) (Eothen LHL 1), Firenze.

S. DE MARTINO - F. IMPARATI, "Sifting through the Edicts and Proclamations of the Hittite Kings", in: S. ALP - A. SÜEL (eds.), Acts of the III International Congress of Hittitology, Ankara, 391-400.

G.F. DEL MONTE, "I testi amministrativi da Maşat Höyük Tapika”, OA Misc. 2, 91-138.

G.F. Del Monte, Le Gesta di Suppiluliuma, Pisa.

L. MASCHERONI, "Scribi hurriti a Boğazköy: una verifica prosopografica", SMEA 24, 151-173.

G. McMahon, The Hittite State Cult of the Tutelary Deities, Chicago.

J.L. Miller, Studies in the Origins, Development and Interpretation of the Kizzuwatna Rituals (StBoT 46), Wiesbaden.

J.L. MiLleR, "Joins and Duplicates among the Boğazköy Tablets (1-10)", ZA 96, 235-241.

J.L MiLlER, "Mursili II's Dictate to Tuppi-Teššub's Syrian Antagonists", KASKAL 4, 121-152. 
Mora 1993

Mora 2004

Mora 2008

Mora 2010

Mouton 2007

Nakamura 2002

Neu 1996

Nowicki 1983

Otten 1951

Otten 1975

Otten 1988

Otten - Rüster 1993

Otten - Souček 1965

Pecchioli Daddi 2003

Pecchioli Daddi 2010
C. MORA, "Lo «status» del re di Kargamiš", Orientalia 62, $67-70$

C. MORA, "Sigilli e sigillature di Karkemiš in età imperiale ittita I. I re, i dignitari, il (mio) Sole", Orientalia 73, 427-450.

C. MORA, "Principi di Karkemiš a Hुattuša: attività e rapporti con il potere ittita", SMEA 50, 555-563.

C. MORA, "Le sigillature multiple nell'archivio di Nişantepe (Hattuša, Città alta)" Orientalia,79,216-231.

A. Mouton, Rêves hittites, Leiden - Boston.

M. NAKAMURA, Das hethitische nuntarriyašḩa-Fest, Leiden.

E. NEU, Das hurritische Epos der Freilassung I (StBoT 32), Wiesbaden.

H. NOwICKI, "Der hurritische Name des Muwattalli", Hethitica 5, 111-118.

H. OtTEN, 'Die hethitischen 'Königslisten' und die altorientalische Chronologie”, MDOG 83, 47-71.

H. OTTEN, Puduhepa. Eine hethitische Königin in ihren Textzeugnisse, Akademie der Wissenschaften und der Literatur, Abhandlungen der Geistes- und Sozialwissenschaftlichen Klasse, Mainz.

H. OtTen, Die Bronzetafel aus Boğazköy (StBoT Bh. 1), Wiesbaden.

H. OTTEN - CHR. RÜSTER, “Ärztin’ im hethitischen Schrifttum", in: M.J. MELLINK - E. PORADA - T. ÖZGÜÇ (eds.), Aspects of Art and Iconography: Anatolia and its Neighbors, Ankara, 539-541.

H. OtTEN - V. SouČEK, Das Gelübde der Königin Puduhepa an die Göttin Lelwani (StBoT 1), Wiesbaden.

F. PECCHIOLI DAdDI, "Le cariche d'oro" in: G. BECKMAN - R. BEAL - G. MCMAHON (eds.), Hittite Studies in Honor of Harry A. Hoffner Jr., Winona Lake, 83-92.

F. PeCCHIOLI DADDI, “LÚ uri(y)anni: una nuova ipotesi di identificazione", Orientalia 79, 232-241. 
Pernigotti 2010

Poetto 2010

Popko 1991

Popko 2007

Prechel 1996

Prechel - Richter 2001

Pruzsinszky 2003

Richter 1998

Richter 2004

Richter 2005

Richter 2008

Richter 2010

Rieken 1999
S. PernigotTi, L'Egitto di Ramesse II tra guerra e pace, Brescia.

M. Poetto, "Nuovi sigilli in luvio geroglifico VII", in: Y. COHEN - A. Gilan - J.L. Miller (eds.), Pax Hethitica (StBoT 51), Wiesbaden, 271-277.

M. POPKO, "Eine ,Schwarze Tafel' aus Boğazköy (KUB LX 121)", AoF 18, 239-245.

M. POPKO, "Zur luwischen Komponente in den Religionen Altanatoliens", AoF 34, 63-69.

D. PRECHEL, Die Göttin Išhara, Münster.

D. PRECHEL - Th. RICHTER, "Abrakadabra oder Althurritisch. Betrachtungen zu einigen altbabylonischen Beschwörungstexten", in: Th. RICHTER - D. PRECHEL - J. KLINGER (eds.), Kulturgeschichten. Altorientalische Studien für Volkert Haas zum 65. Geburtstag, Saarbrücken, 333-372.

R. PRUZSINSZKY, Die Personennamen der Texte aus Emar (SCCNH 13), Bethesda.

TH. RichteR, "Anmerkungen $\mathrm{zu}$ den hurritischen Personennamen des hapiru-Prismas aus Tigunānum", SCCNH 9, 125-134.

TH. RichTER, "Die Ausbreitung der Hurriter bis zur altbabylonischer Zeit: eine kurze Zwischenbilanz", in: J.W. MEYER - W. SOMMERFELD (eds.), 2000 v.Chr. Politische, Wirtschaftliche und Kulturelle Entwicklung im Zeichen einer Jahrtausendwende, Saarbrücken, 263-311.

TH. RICHTER, "Hurriter und Hurritisch in Syrien", in: D. PRECHEL (ed.), Motivation und Mechanismen des Kulturkontaktes in der Späten Bronzezeit (Eothen 13), Firenze, 145-178.

TH. RICHTER, "Šuppiluliuma I. in Syrien", in: G. WilHeLM (ed.), Hattuša-Boğazköy (CDOG 6), 173-203.

TH. RICHTER, "Ein Hurriter wird geboren... und benannt", in: J. BECKER - R. HEMPELMANN - E. REHM (eds.), Kulturlandschaft Syrien (AOAT 371), Münster, 505-528.

E. RIEKEN, Untersuchungen zur nominalen Stammbildung des Hethitischen (StBoT 44), Wiesbaden. 
Rieken 2009

Riemschneider 1958

de Roos 1998

de Roos 2005

de Roos 2006

de Roos 2007

Röseler 1999

Rutherford 2004

Salvini 1991

Salvini 1996a

Salvini 1996b

Salvini - Wegner 1986

Sasson 1974

Sasson 1979
E. RIEKEN, "Die Tontafelfunde aus Kayalıpinar", in: F. PeCCHIOli DAdDI - G. TORRI - C. CORTI (eds.), CentralNorth Anatolia in the Hittite Period, Roma, 119-143.

K.K. RIEMSCHNEIDER, "Die hethitische Landschenkungsurkunden”, MIO 6, 321-381.

J. DE Roos, "A Few Missing Hittite Tablet", AoF 25, 158162.

J. DE Roos, "Who was Kilušhepa?", JEOL 29 (19851986), 74-83.

J. DE Roos, "Materials for a Biography: The Correspondence of Puduhepa with Egypt and Ugarit", in: TH. VAN DEN Hout (ed.), The Life and Times of Hattušili III and Tuthaliya IV, Leiden, 17-26.

J. DE Roos, Hittite Votive Texts, Leiden.

I. RÖSELER, "Hurritologische Miszellen", SCCNH 10, 393-400.

I.C. RUTHERFORD, "Women Singers and Religious Organisation of Hatti. On the Interpretation of CTH 235.1 \& 2 and Other Texts" in: M. HutTer - S. HutTERBRAUNSAR (eds.), Offizielle Religion, locale Kulte und individuelle Religiosität, Münster, 377-394.

M. SAlvini, "Note su alcuni nomi di persona hurriti", SEL 8, 175-180.

M. SAlvini, The habiru Prism of King Tunip-Teššup of Tikunani, Roma.

M. SAlvinI, "Excursus: The Name Tupkiš", apud G. Buccellati - M. Kelly Buccellati, "The Seals of the King of Urkesh: Evidence from the Western Wing of the Royal Storehouse AK", WZKM 86, 84-86.

M. SAlvini - I. Wegner, Die Rituale des AZU-Priesters (ChS I/2), Roma.

J.M. SASSON, "Hurrians and Hurrian Names in the Mari Texts", UF 6, 353-400.

J.M. SASSON, "Hurrian Personal Names in the Rimah Archives", Assur 2, 37-68. 
Siegelová 1986

Simon 2009

Singer 1983

Singer 1991

Singer 1999

Singer 2001

Singer 2002a

Singer $2002 b$

Singer 2003

Singer 2006a

Singer $2006 b$

Singer 2008

Singer 2010

Van Soldt 1990
J. SiEgElovÁ, Hethitische Verwaltungspraxis im Lichte der Wirtschafts- und Inventardokumente, Praha.

Zs. SIMON, "Die ANKARA-Silberschale und das Ende des hethitischen Reiches", ZA 99, 247-269.

I. SINGER, "Takuhlinu and Haya: Two Governors in the Ugarit Letter from Tel Aphek", Tel Aviv 10, 3-25.

I. SINGER, "A concise History of Amurru", in: SHL. IZRE'El (ed.), Amurru Akkadian: A Linguistic Study, Atlanta, 135-195.

I. SINGER, "A Political History of Ugarit", in: W.G.E. WATSON - N. WYATT (eds.), Handbook of Ugaritic Studies, Leiden - Boston - Köln, 603-733.

I. Singer, "The Title 'Great Princess' in the Hittite Empire", UF 23, 327-338.

I. Singer, "Danuhepa and Kurunta", in: S. DE MARTINO F. PECCHIOLI DAdDI (eds.), Anatolia Antica (Eothen 11), Firenze, 739-751.

I. SINGER, Hittite Prayers, Atlanta.

I. SINGER, "The Great Scribe Taki-Šarruma", in: G. BECKMAN - R. BEAL - G. MCMAHON (eds.), Hittite Studies in Honor of Harry A. Hoffner Jr., Winona Lake, 341-348.

I. SINGER, "The failed reforms of Akhenaten and Muwatalli", British Museum Studies in Ancient Egypt and Sudan 6, 37-58.

I. SINGER, "Ship Bound for Lukka: A New Interpretation of the Companion Letters RS. 94.2530 and RS 94.2523", AoF 33, 242-262.

I. Singer, "Purple-Dyers in Lazpa", in: B.J. Collins M.R. BACHAROVA - I.C. RuthERFORD (eds.), Anatolian Interfaces, Oxford, 21-43.

I. SingER, "Mahhhaza, King of Amurru", in: J. KLINGER E. RIEKEN - CHR. RÜSTER (eds.), Investigationes Anatolicae (StBoT 52), Wiesbaden, 271-277.

W.H. VAN SOLDT, Rev. of J.HUEHNERGARD 1987, BiOr 47, 728-736. 
van Soldt 2003

Starke 1985

Stefanini 1962

Strauss 2001

Strauss 2006

Szabó 1971

Taggar-Cohen 2006

Taracha 2004

Taracha 2005

Tischler 1978

Trémouille 1997

Torri 2005

Ünal 1974

Ünal 1978

Ünal 1987

Ünal 1996
W.H. VAN SOLDT, "The Use of Hurrian Names at Ugarit", UF 35, 681-705.

F. StARKE, Die keilschrift-luwischen Texte in Umschrift (StBoT 30), Wiesbaden.

R. StefaninI, "Studi Ittiti”, Athenaeum 40, 3-36.

R. Strauss, "Eine Rezeptur und Beschwörung für die Zubereitung von "Weihwasser" in dem Ritual CTH 471", in: TH. Richter - D. PRECHEL - J. KLINGER (eds.), Kulturgeschichten. Altorientalische Studien für Volkert Haas zum 65. Geburtstag Saarbrücken, 405-416.

R. STRAUSS, Reinigungsrituale aus Kizzuwatna, Berlin New York.

G. SzABÓ, Ein hethitisches Entsühnungsritual (THeth 1), Heidelberg.

A. TAggar-CoHen, Hittite Priesthood (THeth 26), Heidelberg.

P. TARACHA, "On the Dynasty of the Hittite Empire", in: D. GRODDEK - S. RÖSSLE (eds.), Šarnikzel. Hethitologische Studien zum Gedenken an Emil Orgetorix Forrer, Dresden, 631-638.

P. TARACHA, "Zur Entwicklung des offiziellen Pantheons im Staats- und dynastischen Kult der hethitischen Grossreichszeit", JANER 5, 89-106.

J. TISCHLER, Hethitisches Etymologisches Glossar, 2, Innsbruck.

M.-C. Tremoullle, ${ }^{d}$ Hebat. Une divinité syroanatolienne (Eothen 7), Firenze.

"Militärische Feldzüge nach Ostanatolien in der mittelhethitischen Zeit", AoF 32, 386-400.

A. ÜNAL, Hattušili III. Teil I (THeth 3), Heidelberg.

A. ÜNAL, Ein Orakeltext über die Intrigen am hethitischen Hof (THeth 6), Heidelberg.

A. ÜNAL, Rev. of KUB 55, BiOr 44, 474-486.

A. ÜNAL, The Hittite Ritual of Hantitašš from the City of Hurma against Troublesome Years, Ankara. 
Ünal 1998

Volk 2004

Wegner 1990

Wegner 2001

Wegner 2007

Weippert 2000

Werner 1967

Wilhelm 1992

Wilhelm 1994

Wilhelm 1996

Wilhelm 1998a

Wilhelm 1998b

Wilhelm 1999
A. ÜNAL, Hittite and Hurrian Cuneiform Tablets from Ortaköy (Çorum), Central Turkey, Istanbul.

K. VOLK, "Beschriftete Objekte aus Tall Mozan/Urkeš", MDOG 136, 87-101.

I. WEGNER, "Phonotaktischer $n$-Verlust in Jussivformen des Boğazköy-Hurritischen”, Orientalia 59, 298-305.

I. Wegner, “'Haus' und 'Hof' im Hurritischen”, in: TH. Richter - D. PRECHEL - J. KLINGER (eds.), Kulturgeschichten. Altorientalische Studien für Volkert Haas zum 65. Geburtstag, Saarbrücken, 441-447.

I. WEGNER, Hurritisch. Eine Einführung. 2., überarbeitete Auflage, Wiesbaden.

M. WeIPPERT, “dNIN.GAL/Nikkal. A.III. In Ägypten und Syrien", RlA 9, 357-359.

R. WERNER, Hethitische Gerichtsprotokolle (StBoT 4), Wiesbaden.

G. WILHELM, "Zum hurritischen Verbalsystem", in: S.R. AnschÜTz (ed.), Texte, Sätze, Wörter und Moneme, Heidelberg, 659-671.

G. Wilhelm, "Kumme und *Kumar: Zur hurritischen Ortsnamenbildung", in: P. CALMEYER - K. HECKER - L. JAKOB-ROST - C.B.F. Walker (eds.), Beiträge zur Altorientalische Archäologie und Altertumskunde, Wiesbaden, 315-319.

G. Wilhelm, "Zu den hurritischen Namen der KültepeTafel kt k/k 4”, SCCNH 8, 335-343.

G. Wilhelm, "Name, Namengebung. D. Bei den Hurritern", R1A 9, 121-127.

G. WILHELM, "Die Inschrift des Tišatal von Urkeš”, in: G. BucCELlati - M. Kelly-BuCCELlati (eds.), Urkesh and the Hurrians, Malibu, 117-143.

G. WILHELM, "L'état actuel et les persectives des etudes hourrites", in: J.M. DURAND (ed.), Amurru 1, Paris, 175187. 
Wilhelm 2003

Wilhelm 2006

Wilhelm 2008

Wilhelm 2009

Yakubovich 2010

Zeeb 2001

Zehnder 2010
G. WILHELM, "König Silber und König Hidam", in: G. BECKMAN - R. BEAL - G. MCMAHON (eds.), Hittite Studies in Honor of Harry A. Hoffner Jr., Winona Lake, 393-395.

G. WilHELM, "Die hurritischsprachige Tafel Kp 05/226", MDOG 138, 233-236.

G. Wilhelm, "Hurrians in the Kültepe Texts", in: J.G. DERCKSEN (ed.), Anatolia and the Jazira during the Old Assyrian Period, Leiden, 181-194.

G. WILHELM, "Demographic Data from Hittite Land Donations", in: F. PECCHIOLI DADDI - G. TORRI - C. CORTI (eds.), Central-North Anatolia in the Hittite Period, Roma, 223-233.

I. YaKubovich, Sociolinguistic of the Luvian Language, Leiden, Boston.

F. ZeEB, Die Palastwirtshaft in Altsyrien (AOAT 282), Münster.

Th. ZEHNDER, Die hethitische Frauennamen (DBH 29), Dresden. 


\section{PERSONAL NAMEs EXAMINED}

Agi-Tešob 54-55

Agiya 27, 28, 33, 35, 63, 75, 77

Ali-ḩešni 30, 31, 36

Ali-p/wašu 27, 77

Ali-Šarruma 15, 22

Alihhinini 33, 55

Allai-turahhi 26, 66

${ }^{\mathrm{f}}$ Ambazzi 26 n. 135

Ari-Šarruma 15, 22

${ }^{\mathrm{f}}$ Aru-Heba 29, 49-50

Ašmi-Šarruma 9-10, 12, 32, 3637

${ }^{\mathrm{f}} \mathrm{Ašmu}-\mathrm{Heba}$ 10, 12

${ }^{f}$ Ašmu-Nikkal 9, 12, 19

${ }^{\mathrm{f}}$ Ašnu-Heba 10, 29, 50

Ašnu-Nikkal 66-67

${ }^{\mathrm{f}} \mathrm{Ašdu} \mathrm{26,} \mathrm{67,} 81$

Attai 10, 12

${ }^{\mathrm{f}}$ Azzari 75-76

${ }^{\mathrm{f}}$ Azziya 78
Ehal-Tešob 27, 74

Ehalte 27, 78

Ehli-Kušuh 32, 37

${ }^{\mathrm{f}}$ Ehli-Nikkal 17

Ehli-Šarruma 15, 22, 32, 37-38

Ehli-Tenu 26, 43

Ehlib-Adda 26, 43

Evri-Šarruma 15, 31, 38, 81

${ }^{\mathrm{f}}$ Heba-muwa 29, 50-51

${ }^{\mathrm{f}}$ Heba-piya 29, 51

${ }^{\mathrm{f}}$ Hebat-uzzi 82

${ }^{\mathrm{f}}$ Hebate 81

${ }^{\mathrm{f}}$ Henti 13

Hešni 15, 30, 33, 36, 55-56, 63

Hismi-Šarruma 15

Hubidi 27-28, 35, 53

Hudu-Tešob 82

Hudubi 27, 76

${ }^{\mathrm{f}}$ Huiya 82 
Hulanabi 31

Hurlanni 27, 78

${ }^{\mathrm{f}}$ Yaru-Heba 28, 79

Ibizzi 30, 33, 56

Ilī-Šarruma 26, 43-44

Kaniu 26

${ }^{\mathrm{f}}$ Kiluš-Heba 15

Kiziya 26, 67-68

Kumarbi 27, 31, 79

${ }^{\mathrm{f}}$ Kuzi 83

Kuzi-Tešob 33, 56

Madi 26, 68

Madi-Šarruma 83

Madu 53

${ }^{f}$ Manniya 33, 63-64

Mittana-muwa 30

Mušu 27, 28, 35-36

${ }^{\mathrm{f}}$ Mušu-Heba 10, 12

Nani 27, 79

Naniya $30,33,64-65$

Naniyanni 26, 68-69

Nigri-Tešob 83-84

${ }^{\mathrm{f}}$ Nikkal-madi 9, 12, 19

${ }^{\mathrm{f}}$ Nikkal-uzzi 33, 72-73
Nulaya 84

Paba-nigri 26, 69

Pandiya 84

${ }^{\mathrm{f}}$ Pattiya16, 50

Pattiyanni 79-80

Pendi[- 54

Pendi-Šarruma 32, 33, 44, 57

Pendi-šena 33, 57-58

Pendib-Šarri 14, 65-66

${ }^{\mathrm{f}} \mathrm{Pudu}-\mathrm{Heba} 14$

Puranda-muwa 30

Purazi 28, 80

fŠabšušu 33, 73

Šahurunuwa 21

f̌̌alašu 26, 70

Šarri-Kušuh 19

Šarri-Tešob 14, 18

Šarrup-šena 80

fŠatandu-Heba 10, 12, 19

Šaušga-muwa 22, 31, 33, 3839,58

Šaušga-piya 31,39

Šaušga-Runtiya 22-23, 31, 33, 39,58

Šaušga-walwi 58 
Šaušga-ziti 51-52

f̌̌aušganu 15

fŠaušgatti 16, 49, 85

fŠilalluhi 70-71

Šindi-Tešob 40

Tadikkanna 33, 59

Tagi-Šarruma 31, 33, 40, 59-60

Tagi-Tešob 40-41

Taguhili 86

Taguya 71

Tagup-šeni 86

Talmi-Šarruma 21

Talmi-Tešob 31, 32, 33, 41, 44$45,60,87$

Talmiya 31,41

${ }^{\mathrm{f}}$ Tanu-Heba 14

Tašmi-Šarri 9, 12, 18

Tašmi-Šarruma 15, 16, 18

${ }^{\mathrm{f}}$ Tadu-Heba 10, 12, 19

Tehi-Tešob 30, 33, 47

Tehup-šeni 33

Teli-Šarruma, 61

Teli-Tešob 33, 47-48

Tulbi(ya) 72

Tulbi-Šarruma 13, 17
Tulbi-Tešob 10, 12, 20, 31

Tuniya 25

Tupkiya 71

Ulmi-Šarruma 61

Ulmi-Tešob 14, 20

${ }^{\mathrm{f}}$ Ummaya 33, 73-74

Urhi-Tešob 14, 18, 20

Zuzzu 28-29

[X]-Šarruma 21 
Finito di stampare in Firenze

nel mese di marzo 2011 


\title{
KASKAL
}

\author{
Rivista di storia, ambienti e culture del Vicino Oriente antico \\ A Journal of History, Environment, and Cultures of the Ancient Near East
}

\section{Vol. 1 (2004)}

Lucio Milano, Weight Stones from Tell Beydar / Nabada

LuCA Marigliano, Creature fantastiche nell'arte mesopotamica del terzo millennio a.C.: esempi iconografici di ibridi uomo-animale

Stefano de MARTinO, König, Gott und Feind in den althethitischen historiographischen Texten

LORENZO D'Alfonso, Gli Ittiti sul Medio Eufrate alle prese con la fonetica semitica (XIII sec. a.C.)

ROSANNA TOGNON, Il testo oracolare ittita KUB V 7

FREDERICK MARIO FALES, Rileggendo gli inventari di Qatna

NicolettA BeLlotTo, L'adozione con matrimonio a Nuzi e a Emar

SimONETTA PONCHIA, Mountain Routes in Assyrian Royal Inscriptions

FORUM

Aage Westenholz, How Do We Understand Ancient History,and Why Study It at All ?

Vol. 2 (2005)

MARTA Bisello, Ruolo del repertorio iconografico nei diversi generi artistici della Mesopotamia protodinastica

MASSIMO MAIOCCHI, Sul valore ponderale del siclo "DILMUN" nei testi di Ebla

Giuseppe Visicato - Aage Westenholz, An Early Dynastic Archive from Ur Involving the lugal

ELENA SANTAGATI, Un registro neo-sumerico di arretrati di orzo e crusca

BENDT Alster, Groats Dropping on the Widow: HS 1461. Studies in Bilingual Proverbs 1

Markham J. Geller, Catalogue of Late Babylonian Ur Texts Excavated by Hall

DAVID SEVALIÉ, Mari e Hazakkanum: analisi dei rapporti politici

MARCO MARIZZA, Un frammento ittita di difficile definizione tipologica: KUB XXIII 83

Daniela Crasso, Ankuwa in Hittite Written Sources: Preliminary Observations

SALVATORE GASPA, Schemi narrativi nelle Summary Inscriptions di Tiglatpileser III: il resoconto delle campagne babilonesi come caso di studio

CyNTHIA JEAn, Des chiens de Ninkilim aux criquets syriaques:ou le succès d'une métaphore en Mésopotamie

FORUM

FrANCIS JOANNES, L'économie et la société en Babylonie au Ier millénaire avant J.-C.

\section{Vol. 3 (2006)}

Elena Rova, The Eagle and the Snake. Remarks on the Iconography of Some Archaic Seals

BARBARA GILLI, Le rappresentazioni dei vasi per gli oli sacri a Saqqara nella VI dinastia

ANDREA BEMPORAD, Considerazioni sulla fine dell'impero ittita

Chicako E. Watanabe, Pictorial Narrative in Assyrian Art: The "Continuous Style" Applied to the Battle of Til-Tuba

Frederick Mario Fales, Treading the (Military, Commercial, And Cultural) Itineraries of The Ancient

Near East (Udine, September 1-3, 2004) - An Introduction

MICHAEL PORTER, Iter Itinerarii

Michael P. StReCK, Travels in the Ancient Near East

Christoph Gerber, “... To Find the Key” - Ein Itinerar zum Verständnis der Stratigraphie der Fürstengräber von Alaca Höyük 


\title{
KASKAL
}

\author{
Rivista di storia, ambienti e culture del Vicino Oriente antico \\ A Journal of History, Environment, and Cultures of the Ancient Near East
}

MASsimo ForLANINI, Étapes et itinéraires entre Assur et l'Anatolie des marchands paléo-assyriens: nouveaux documents et nouveaux problèmes

David SeVALIÉ, Les itinéraires de la communication à Mari sous le règne de Zimrî-Lîm

MinNa LÖNNQVIST, Archaeological Surveys of Jebel Bishri. The Preliminary Report of the Finnish Mission to Syria, 2000-2004

CinZIA PAPPI, The Jebel Bishri in the Physical and Cultural Landscape of the Ancient Near East

Leonardo Gregoratti, Vespasiano, Marco Ulpio Traiano padre e la costituzione del limes orientale FORUM

Aage Westenholz, Does Assyriology Have a Future?

\section{Vol. 4 (2007)}

Anna Brustolon - Elena Rova, The Late Chalcolithic Period in the Tell Leilan Region: A Report on the Ceramic Material of the 1995 Survey

Francesca De Lillis Forrest - Lucio Milano - Lucia Mori, The Akkadian Occupation in the Northwest Area of the Tell Leilan Acropolis (with an Appendix on The Epigraphic Finds from the "Tablet Room" of the Leilan IIb3 Akkadian Building and from Later Akkadian Layers)

Elena Santagati, Girsu "Messenger Texts" Kept in the British Museum

Cristiana Molfese, Prime manifestazioni dello "stile internazionale" nel Medio Bronzo? Il caso dei sigilli e degli avori

Emanuele M. Ciampini, Two New Coffin Sides from the Tomb of Henib

Jared L. Miller, Mursili II’s Dictate to Tuppi-Teššub’s Syrian Antagonists

MARCO MARIZZA, The office of GAL GEŠTIN in the Hittite Kingdom

FRANCESCO FUSCAGNI, Una nuova interpretazione del rituale CTH 423 alla luce di tre nuovi duplicati

GABRIELLA STIVALA, L'apporto della lingua hattica alla tradizione cultuale ittita: due casi di canti strofici

Maurizio Viano, Problemi di datazione di alcuni testi legali di Emar

PaOla Corò, Again on an Achaemenid Contract from the Egibi Archive in Trieste (Italy): Collations to Inv. 138

GiUlIA FrANCESCA GRASSI, L'onomastica di Dura-Europos: alcune considerazioni d'insieme

FORUM

Claus Ambos, Ricostruire un tempio per nuocere al re: rituali mesopotamici di fondazione, il loro posto nel culto e il loro impiego come arma politica

\section{Vol. 5 (2008)}

CLAudia E. Suter, Who are the Women in Mesopotamian Art from ca. 2334-1763 BCE?

MARTiN BOMMAS, Die verstorbenen Könige im kulturellen Gedächtnis des Alten Ägypten

Maria Emanuela Alberti, Murex Shells as Raw Material: the Purple-Dye Industry and Its By-products. Interpreting the Archaeological Record

Papers Presented at the Verona Workshop (2007) on

"Administration AND IDEOLOGY IN THE ANCIENT NEAR EAST"

Walther Sallaberger, Rechtsbrüche in Handel, Diplomatie und Kult. Ein Memorandum aus Ebla über Verfehlungen Maris (ARET 13,15)

Hagan BRUnKe, The nakabtum. An Administrative Superstructure for the Storage and Distribution of Agricultural Products

Paola PaoletTi, Elusive Silver? Evidence for the Circulation of Silver in the Ur III State

Papers Presented at the VIU 2006-2007 Seminar on

"Literature and Culture in the Ancient Mediterranean: Greece, Rome and the NEAR EAST" 


\title{
KASKAL
}

\author{
Rivista di storia, ambienti e culture del Vicino Oriente antico \\ A Journal of History, Environment, and Cultures of the Ancient Near East
}

JEFFREY L. COOLEY, Inana and Šukaletuda: a Sumerian Astral Myth

Alexandra Kleinerman, Money, Memory and Miscellany: Understanding the Presence of Historical Elites in Early Second Millennium Pedagogical Composition

GiUlia F. Grassi, Belshazzar's Feast and Feats: the Last Prince of Babylon in Ancient Eastern and

Western Sources

Martin LANG, Floating from Babylon to Rome: Ancient Near Eastern Flood Stories in the

Mediterranean World

ERIK VAN DONGEN, The Study of Near Eastern Influences on Greece: towards the Point

Vol. 6 (2009)

Minna LÖNNQVIST, Archaeological Surveys of Jebel Bishri. The Preliminary Report of the Finnish

Mission to Syria, 2005-2006

WolfGang HeImPEL, Blind Workers in the Ur III Texts

Massimo Forlanini, Upper Mesopotamia in the Middle of the 17th Century B.C. according to the Hittite Texts

FrANCESCO FusCAGNI, An Unpublished Hittite Fragment of an Evocation Ritual: 894/Z

Nicla De ZorZI, Bird Divination in Mesopotamia. New Evidence from BM 108874

DAVIDE NADALI, Sieges and Similes of Sieges in the Royal Annals: The Conquest of Damascus by

Tiglath-Pileser III

Radosław TARASEwicZ, Bird Breeding in Neo-Babylonian Sippar

STEFAn ZAWADZKI, A Document concerning the Sale of an Ass from Persian Sippar

FORUM

Fumi Karahashi, Argument Structure of Sumerian Verbs: Causative Alternation

Frederick Mario Fales, Art, Performativity, Mimesis, Narrative, Ideology, and Audience: Reflections on Assyrian Palace Reliefs in the light of Recent Studies

\section{Vol. 7 (2010)}

Monica Arrivabeni, Early Bronze Age Settlement in the Tell Leilan Region: A Report on the Ceramic Material of the 1995 Survey

Licia Romano, Who was Worshipped in the Abu Temple at Tell Asmar?

ItZHAQ SHAI - Joe UzIEL, The Whys and Why Nots of Writing: Literacy and Illiteracy in the Southern Levant during the Bronze Ages

MARCo MARIZZA, La papponimia nel mondo ittita. Casi accertati e casi presunti

Papers Presented at the VIU 2008-2009 Seminar on

"Literature and Culture in the Ancient Mediterranean: Greece, Rome and the Near East"

Christian W. Hess, Towards the Origins of the Hymnic Epic Dialect

MARTIN WorTHINGHTON, mamma(n) ... ul and Its Alternatives in Babylonian Literature

Alexa Bartelmus, Restoring the Past. A Historical Analysis of the Royal Temple Building Inscriptions from the Kassite Period

LuISA BARBATO, Rhetoric of Landscape in the Assyrian Royal Inscriptions from Sargon II to Ashurbanipal

ANgela R. Roskop, Deluge, War, and Dios Boulê: Making Sense of Cross-Cultural Affinities in the Biblical Flood Story

FORUM

MASSIMILIANO MARAZZI, Scrittura, percezione e cultura: qualche riflessione sull'Anatolia in età ittita 
13. Motivation und Mechanismen des Kulturkontaktes in der Späten Bronzezeit. Herausgegeben Doris Prechel. 2006. XVI-280 p., in-8 ISBN 97888-87621-586 €63,00

Inhaltsverzeichnis: Doris Prechel, Einleitung; Daliah Bawanypeck, Arzawäische Ritualpraktiken - Informationen aus Hattuşa; Lorenzo d'Alfonso, Free, Servant and Servant of the King: Conflict and Change in the Social Organisation at Emar after the Hittite Conquest; Johan de Roos, Die Hethiter und das Ausland; Helmut Freydank, Beispiele von Kulturkontakten aus mittelassyrischer Zeit; Mauro Giorgieri, Bedeutung und Stellung der „,mittanischen“ Kultur im Rahmen der Kulturgeschichte Vorderasiens; Jörg Klinger, Die hethitische Rezeption mesopotamischer Literatur und die Überlieferung des Gilgameš-Epos in Hattuşa; Jared L. Miller, Von Syrien durch Kizzuwatna nach Hatti: Die Rituale der Allaiturahhi und Giziya; Thomas Richter, Hurriter und Hurritisch im bronzezeitlichen Syrien; Silke Roth, «Im schönen Frieden befriedet und in schöner Brüderschaft verbrüdert». Zu Motivation und Mechanismen der ägyptisch-hethitischen diplomatischen Kontakte in der Zeit Ramses II; Rita Strauß, Elemente kizzuwatnäischer Ritualkunde in hethitischen Texten; Wilfred van Soldt, Von Königen, Beamten und Schreibern: Die Kontakte von Ugarit mit seiner Umwelt.

14. Michele Cammarosano, Il Decreto antico-ittita di Pimpira.
2006. 80 p., in-8
ISBN 97888-87621-594 €27,00

Indice: Abbreviazioni / 1 - Introduzione / 2 - I manoscritti / 3 - La tradizione manoscritta: redazioni e varianti / 4 - Il testo / 5 - Commento / 6 - Datazione di KBo III 23 / 7 - Pimpira: chi era costui? / Glossario / Riferimenti bibliografici

15. Marco Marizza, Dignitari ittiti al tempo di Tuthaliya I/II, Arnuwanda I, Tuthaliya III. 2007. 196 p., in-8 ISBN 97888-87621-675 €38,00

Abbreviazioni; Introduzione; I. La fase finale del Medio Regno; II. I figli di Arnuwanda I e Ašmunikal; Dignitari di KBo 8.55+ e KBo 16.97; III. Pišeni; IV. Muwatalli; V. Tuttu; Dignitari di KBo 5.7; VI. Duwa; VII. Ḩalpaziti; VIII. Ḩulla e Tarhumima; Dignitari da Maşat Höyük; IX. Kaššu; X. Hुimuili; XI. Hattušili; XII. Šahurunuwa; Appendice onomastica; English Summary; Bibliografia; Indici e tavole

16. New Perspectives in the Historical Geography of Anatolia in the $2^{\text {nd }}$ and $1^{\text {st }}$ Millennium B.C. 2008. 304 p., ill., tavv., 17x24

ISBN 97888-87621-808

$€ 63,00$

Summary: K. Strobel, Neues zur Geographie und Geschichte des Alten Anatolien. Eine Einführung mit Beiträgen zur Hethitischen Geographie des westlichen Anatolien; O. Carruba, Analisi delle liste reali etee; D. Crasso, The location of Ankuwa and the geographic connections with the capital and the neighbouring towns; S. de Martino, The Hittite sity of Samuha. Its location and its religious role in the Middle Kingdom; M. Forlanini, The central provinces of Hatti: an updating, C. Gerber, New insights into the settlement history of the Taviun region; C. Michel, Nouvelles données de Géographie historique anatolienne d'après des archives récents de Kültepe; S. Ponchia, Looking itineraries in Central Anatolia in the First Millennium B.C.; K. Strobel, Tawinija/Tavium and the Regional Hittite Road Network.

\section{LITERATUR ZUM HURRITISCHEN LEXIKON}

Stefano de Martino - Mauro Giorgieri, Literatur zum Hurritischen Lexikon, (LHL), Band 1 - A. 2008. 192 p., $17 \times 24$ ISBN 97888-87621-709€38,00 